\title{
ATLAS OF VESSEL ELEMENTS
}

\section{Identification of Asian Timbers}

Stephanie Helmling ${ }^{1}$, Andrea Olbrich ${ }^{2, *}$, Immo Heinz ${ }^{2}$, Gerald Koch ${ }^{2}$

${ }^{1}$ University of Hamburg, Department of Wood Biology and Technology, Leuschnerstraße 91, D-21031 Hamburg, Germany

${ }^{2}$ Johann Heinrich von Thünen Institute (TI), Institute of Wood Research, Leuschnerstraße 91, D-21031 Hamburg, Germany

*Corresponding author. E-mail: andrea.olbrich@thuenen.de

(C) 2018. IAWA Journal 39 (3): 249-352

International Association of Wood Anatomists

c/o Naturalis Biodiversity Center, Leiden, The Netherlands

DOI 10.1163/22941932-20180202 


\section{Contents}

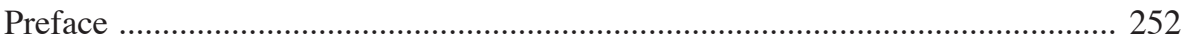

How to use the vessel element atlas ................................................................. 253

Preparation of pulp samples for identification with the light microscope ............. 254

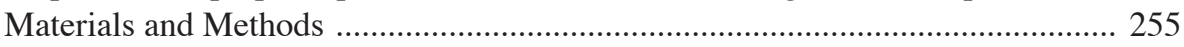

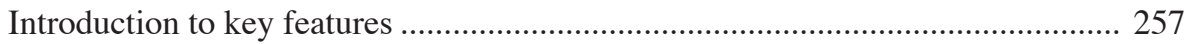

Descriptions of woody angiosperms of tropical and temperate Asia .................... 266

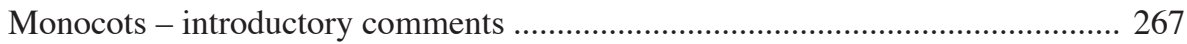

Dendrocalamus latiflorus Munro (Poaceae) .................................................... 268

Cocos nucifera L. (Arecaceae).................................................................... 270

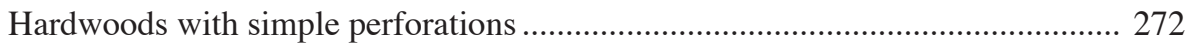

"APS" (All Pits Similar in size and shape) - introductory comments ................. 272

Avicennia marina (Forssk.) Vierh. (Acanthaceae) ........................................... 274

Lophopetalum sp. (Celastraceae) .................................................................. 276

Koompassia malaccensis Maingay ex Benth. (Fabaceae-Caesalpinioideae) ... 278

Intsia sp. (Fabaceae-Caesalpinioideae) .......................................................... 280

Acacia mangium Willd. (Fabaceae-Mimosoideae) ………………………….... 282

Albizia procera (Roxb.) Benth. (Fabaceae-Mimosoideae) ................................ 284

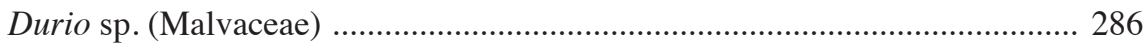

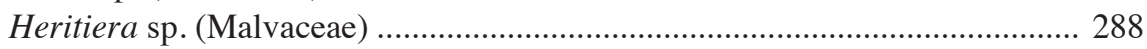

Paulownia tomentosa (Thunb.) Steud. (Paulowniaceae) ................................. 290

Tetramerista glabra Miq. (Tetrameristaceae) ................................................. 292

Gonystylus sp. (Thymelaeaceae) ..................................................................... 294

“VAS" (Vessel-ray pits Apparently Simple) - introductory comments ................. 296

Campnosperma sp. (Anacardiaceae).............................................................. 298

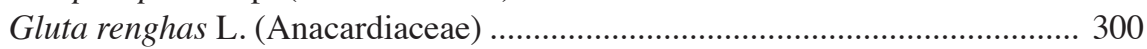

Mangifera sp. (Anacardiaceae) …………………………........................ 302

Swintonia sp. (Anacardiaceae) ...................................................................... 304

Canarium sp. (Burseraceae) ........................................................................ 306

Calophyllum sp. (Calophyllaceae) .............................................................. 308

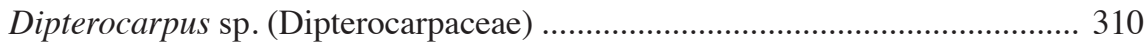

Parashorea sp. (Dipterocarpaceae) ............................................................... 312

Shorea subg. Anthoshorea (Dipterocarpaceae) ................................................ 314

Shorea subg. Richetia (Dipterocarpaceae) ………………………………..... 316

Shorea subg. Rubroshorea (Dipterocarpaceae) ................................................ 318

Shorea subg. Shorea (Dipterocarpaceae) ....................................................... 320

Hevea brasiliensis (Willd. ex A. Juss.) Müll. Arg. (Euphorbiaceae).................. 322

Castanopsis argentea (Blume) A. DC. (Fagaceae) .......................................... 324

Litsea resinosa Blume (Lauraceae) ................................................................. 326 
Eucalyptus globulus Labill. (Myrtaceae) ..................................................... 328

Syzygium dyerianum (King) Chantaran. \& J. Parn. (Myrtaceae) ..................... 330

Madhuca sericea (Miq.) S. Moore (Sapotaceae) ............................................ 332

Palaquium sp. (Sapotaceae) ....................................................................... 334

Hardwoods with scalariform perforation plates - introductory comments ........... 336

Liquidambar formosana Hance (Altingiaceae) .............................................. 338

Ilex triflora var. kanehirai (Yamamoto) S.Y. Hu (Aquifoliaceae) .................... 340

Nyssa javanica (Blume) Wangerin (Nyssaceae) .............................................. 342

Rhizophora sp. (Rhizophoraceae) ............................................................ 344

Alniphyllum pterospermum Matsum. (Styracaceae)....................................... 346

Schima superba Gardn. \& Champ. (Theaceae) ............................................. 348

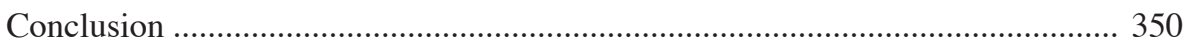

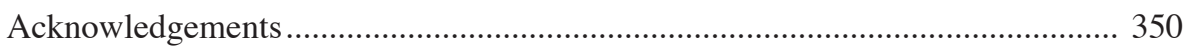

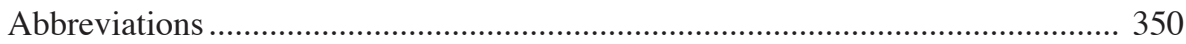

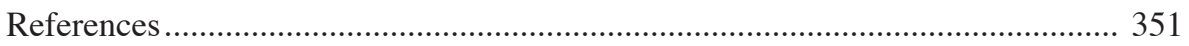


Pulp production is increasing worldwide, especially in Southeast Asia and China (WWF 2009; Williams 2014; FAO 2015), and the use of tropical timbers from natural forests is not uncommon (Greenpeace 2012). To ensure that no protected timbers are used, those detected in pulp and paper products must be identified.

Individual vessel elements are best suited for the microscopic identification of wood species in those products on the basis of typical morphological features such as type of perforation plates, presence $v s$. absence of helical thickenings, and type and arrangement of vessel-ray pits (Core et al. 1979; Carlquist 2001).

To allow identification, a standardized morphological description of these features is required for commonly used timber. The fiber atlases by Carpenter and Leney (1952), Ezpeleta and Simon (1970, 1971), Harders-Steinhäuser (1974), Parham and Gray (1982) and Ilvessalo-Pfäffli (1995) describe these characteristics for the main species grown in the temperate zone and in plantations. There is, however, no corresponding database available for important Asian timbers.

In recent years, the rapid and reliable identification of wood species and their origin has become necessary (e.g. Dormontt et al. 2015; Koch \& Schmitt 2015; Koch et al. 2015), owing to the following laws that have recently come into effect: the U.S. Lacey Act (USA, 1900 /amended in 2008), the Illegal Logging Prohibition Act 2012 (Australia), and the European Timber Regulation (EUTR, No. 995/2010. implemented in 2013). Besides other timber products, these laws subject the fiber components of pulp and paper to strict controls, aiming to minimize the trade and use of illegally logged timber or products derived from it. Both producers and traders of wood products are responsible for the correct declaration of the species and origin (Koch \& Schmitt 2015).

To support the request for due diligence, our team from the University of Hamburg and the Thünen Institute (Hamburg, Germany) developed this atlas of vessel elements for the identification of Asian timbers, with funding from the German Environmental Foundation (Deutsche Bundesstiftung Umwelt, DBU). The vessel atlas describes 38 tropical and temperate Asian timbers, known for their potential in utilization of pulp and paper, including for the first time also lesser known species and the monocots Bamboo and Coconut palm. Each species is illustrated with high-quality photomicrographs at standard magnification.

Important diagnostic features are highlighted in the text and figures for easy identification. The taxonomy of the individual species is described in detail in the PROSEA Timber volumes (Soerianegara et al. 1993; Lemmens et al. 1995; Sosef et al. 1998). The selection of the taxa depends on the evaluation of about 2,150 official reports prepared at the Thünen Centre of Competence on the Origin of Timber since the implementation of the EUTR (2013) in Germany. Based on this experience, the atlas includes the commonly used timbers regularly identified in fiber boards, pulp, and paper from Asia, e.g. Liquidambar, Nyssa and Schima. Furthermore, taxa with wide distribution and high economic potential, e.g. of the families Dipterocarpaceae, Sapotaceae, etc. are considered (Helmling et al. 2016). 
Reference materials for the morphological description of the vessel elements are provided from vouchered specimens of the scientific wood collection (RBHw) of the Thünen Institute. Furthermore, well-documented assortments of mono-fractioned pulp (each pulp consisting of specimens belonging to a single genus) were produced separately to study the influence of mechanical impact on the morphology of carefully macerated vessel elements (not damaged) and mechanically pulped fibers (partly damaged). Paper sheets of unknown mixtures (blind test) were also produced and microscopically analyzed to assess the applicability of the information contained in the atlas. The verifiable results of the blind tests clearly demonstrated the usefulness of the atlas.

Based on this experience, the atlas should be understood as an aid to wood identification in pulp and paper, to be used as a supplement to the existing fiber atlases, in particular the atlas by Ilvessalo-Pfäffli (1995) with descriptions of tree species mainly used in the pulp and paper production.

We trust that by displaying the considerable variety of vessel elements in Asian timbers, this atlas will assist in identifying tropical and temperate woody genera in pulp, paper, and fiber board. We also hope that it may help to preserve protected tree species.

Stephanie Helmling, Andrea Olbrich, Immo Heinz, Gerald Koch Hamburg, Germany 2018

\section{HOW TO USE THE VESSEL ELEMENT ATLAS}

This atlas contains the description of individual wood species, but the features may also be valid for the respective genus as the similarity within genera is often very high.

The identification of the material used in pulp, paper and fiber boards is a challenging task due to the missing tissue structure. The separated wood fibers offer less information than solid wood tissue. Furthermore, pulp often consists of a mixture of different wood species which makes identification even more difficult.

The wood identification also depends on the method of pulp production. If the pulp was strongly refined, the limits of wood identification have been reached.

It is possible to determine the family and often the genus. Individual species within a genus are too similar to distinguish them. To identify a timber the sample of pulp and paper products or fiber boards must be compared with the pictures of this atlas. In the case of having identified, e.g., Eucalyptus globulus, according to the similarity of investigated vessel elements with the pictures in this atlas, one can only conclude that the cells have highest similarity with cells of Eucalyptus spp.

The standard species for the production of pulp and paper from temperate zones are well described in the atlases of Parham and Gray (1982) and Ilvessalo-Pfäffli (1995). The present atlas deals with a selection of Asian timbers. For the identification of wood species in pulp and paper of unknown provenance it makes sense to use these atlases together. 


\section{PREPARATION OF PULP SAMPLES FOR IDENTIFICATION WITH THE LIGHT MICROSCOPE}

\section{Paper}

To prepare the samples for investigation, a piece of paper $\left(1.5 \mathrm{~cm}^{2}\right)$ is put into a test tube filled with distilled water to soften the paper. After a few minutes the pulp mass is rolled to a ball between the fingers and placed in a tube with water again. By shaking the test tube the fibers are individualized and the fiber suspension is poured on a filter. Part of the material is then placed on 2 or 3 microscopic slides. Staining of the fibrous mix is done with two drops of Alexander and one drop of Herzberg solutions. Alexander solution (Merck KGaA, Darmstadt, Germany) consists of calcium nitrate tetrahydrate, Herzberg solution (Harders-Steinhäuser 1974) of zinc chloride and potassium iodide (Merck KGaA, Darmstadt, Germany). Cover glasses are placed on the stained pulp, and slides should be investigated immediately, since the staining is not permanent. After this process untreated cells with a high amount of lignin (mechanical pulp) are stained yellow, delignified cells (chemical pulp) are greyish blue (softwoods) or blue (hardwoods).

\section{Medium Density Fiber board (MDF)}

To prepare MDF samples, a piece of the material is boiled in water and the resulting pulp placed on a filter. For better contrast, the pulp is stained with nigrosin (1\%) (alcohol soluble, Alfa Aesar GmbH \& Co. KG, Karlsruhe). After 10-15 minutes the material is rinsed with de-ionised water and mounted in glycerine (86\%, Carl Roth GmbH \& Co. KG, Karlsruhe, Germany) on microscope slides.

\section{Recommendations}

Since there are many more fibers than vessel elements in the pulp it is important to obtain a representative range of vessel elements of the used species. Therefore, it is recommended to investigate enough material which usually requires observation of several microscope slides.

For the production of permanent slides it is useful to increase the contrast by staining the samples with nigrosin $(1 \%$, alcohol soluble, Alfa Aesar GmbH \& Co. KG, Karlsruhe) or safranine (4\%, alcohol soluble, Chroma-Gesellschaft Schmid \& Co. Stuttgart-Untertürckheim). The stained vessel elements of the pulp are selected by needle, placed on microscope slides and mounted in Euparal (Carl Roth GmbH \& Co. KG, Karlsruhe, Germany). 


\section{MATERIALS AND METHODS}

This atlas contains 38 wood species that mainly originate from Southeast Asia (see Table 1). We selected commonly traded timbers, widely used plantation species, and species from endangered habitats. However, it should be stressed that the selection is far from comprehensive, and that other tree species than those treated here may be present in pulp and paper or MDF from Asia.

Authenticated specimens of the wood collection of the Thünen Institute (RBHw, Hamburg, Germany) served as reference material. The descriptions are generally based on one specimen per species only, but features were verified with slides and literature data from the databases in Hamburg and InsideWood (2004-onwards).

The selection of the material and the method (maceration according to Franklin, 1945) are also described by Helmling et al.(2016). Microscopy and staining are included.

The botanical names were taken from:

Catalogue of life (http://www.catalogueoflife.org/col/search).

Flora of China (www.efloras.org).

Grin (https://npgsweb.ars-grin.gov).

Mabberley (2008).

The trade names were taken from:

Brink M \& Escobin RP (2003).

Flora of China (www.efloras.org).

Hayashi (1973), Wong (2002), and Jiang (2013).

Lemmens RHMJ, Soerianegara I \& Wong WC (1995).

Richter HG \& Dallwitz MJ (2000 onwards).

Soerianegara I \& Lemmens RHMJ (1993).

Sosef MSM, Hong LT \& Prawirohatmodjo S (1998).

The codes in the taxon descriptions refer to DIN EN 13556:2003.

The information on geographic distribution of the wood species was extracted from:

Catalogue of life (http://www.catalogueoflife.org/col/search).

Grin (https://npgsweb.ars-grin.gov).

Lemmens RHMJ, Soerianegara I \& Wong WC (1995).

Richter HG \& Dallwitz MJ (2000 onwards).

Soerianegara I \& Lemmens RHMJ (1993).

Sosef MSM, Hong LT \& Prawirohatmodjo S (1998).

The investigated characters of all species were compared with data in literature:

Brink M \& Escobin RP (2003).

InsideWood (http://insidewood.lib.ncsu.edu/search).

Lemmens RHMJ, Soerianegara I \& Wong WC (1995).

Richter HG \& Dallwitz MJ (2000 onwards).

Soerianegara I \& Lemmens RHMJ (1993).

Sosef MSM, Hong LT \& Prawirohatmodjo S (1998). 
Table 1. List of investigated species in alphabetical order of families $(\mathrm{RBHw}=$ vouchered material, $*=$ commercial sample - genus verified).

\begin{tabular}{|c|c|c|c|}
\hline Family & Taxa/species & Trade name & RBHw No. \\
\hline Acanthaceae & Avicennia marina (Forssk.) Vierh. & Api-Api (mangrove) & 24226 \\
\hline Altingiaceae & Liquidambar formosana Hance & Formosan sweet gum & 23479 \\
\hline Anacardiaceae & Campnosperma sp. & Terentang & * \\
\hline Anacardiaceae & Gluta renghas $\mathrm{L}$. & Rengas & * \\
\hline Anacardiaceae & Mangifera sp. & Mango & $*$ \\
\hline Anacardiaceae & Swintonia sp. & Merpauh & * \\
\hline \multirow[t]{2}{*}{ Aquifoliaceae } & Ilex triflora var. kanehirai (Yamamoto) & & \\
\hline & S.Y.Hu & Kecemang & 10148 \\
\hline Arecaceae & Cocos nucifera $\mathrm{L}$. & Coconut palm & $*$ \\
\hline Burseraceae & Canarium sp. & Kedondong & * \\
\hline Calophyllaceae & Calophyllum sp. & Bintangor & * \\
\hline Celastraceae & Lophopetalum sp. & Perupok & * \\
\hline Dipterocarpaceae & Shorea subg. Anthoshorea & White Meranti & * \\
\hline Dipterocarpaceae & Shorea subg. Richetia & Yellow Meranti & * \\
\hline Dipterocarpaceae & Shorea subg. Rubroshorea & Dark/Light Red Meranti & * \\
\hline Dipterocarpaceae & Shorea subg. Shorea & Bangkirai, Balau & * \\
\hline Dipterocarpaceae & Parashorea sp. & Gerutu & * \\
\hline Dipterocarpaceae & Dipterocarpus sp. & Keruing & * \\
\hline \multirow[t]{2}{*}{ Euphorbiaceae } & Hevea brasiliensis (Willd. ex A.Juss.) & & \\
\hline & Müll. Arg. & Rubberwood & 9880 \\
\hline \multicolumn{4}{|l|}{ Fabaceae- } \\
\hline Caesalpinioideae & Intsia sp. & Merbau & * \\
\hline \multicolumn{4}{|l|}{ Fabaceae- } \\
\hline Caesalpinioideae & $\begin{array}{l}\text { Koompassia malaccensis Maingay ex } \\
\text { Benth. }\end{array}$ & Kempas & * \\
\hline Fabaceae-Mimosoideae & Acacia mangium Willd. & Acacia & $*$ \\
\hline Fabaceae-Mimosoideae & Albizia procera (Roxb.) Benth. & White siris, Kokko & 193 \\
\hline Fagaceae & Castanopsis argentea (Blume) A. DC. & Berangan & 18490 \\
\hline Lauraceae & Litsea resinosa Blume & Medang & 15426 \\
\hline Malvaceae & Durio sp. & Durian & * \\
\hline Malvaceae & Heritiera sp. & Mengkulang & $*$ \\
\hline Myrtaceae & Eucalyptus globulus Labill. & Eucalyptus & * \\
\hline Myrtaceae & $\begin{array}{l}\text { Syzygium dyerianum (King) Chantaran. } \\
\text { \& J. Parn. }\end{array}$ & Kelat & 3854 \\
\hline Nyssaceae & Nyssa javanica (Blume) Wangerin & Tupelo, Nyssa & 13989 \\
\hline Paulowniaceae & Paulownia tomentosa (Thunb.) Steud. & Paulownia & 5531 \\
\hline Poaceae & Dendrocalamus latiflorus Munro & Bamboo & 22667 \\
\hline Rhizophoraceae & Rhizophora sp. & Red Mangrove & 24661 \\
\hline Sapotaceae & Madhuca sericea (Miq.) S. Moore & Bitis & * \\
\hline Sapotaceae & Palaquium sp. & Nyatoh & $*$ \\
\hline Styracaceae & Alniphyllum pterospermum Matsum. & Mee Dong & 10151 \\
\hline Tetrameristaceae & Tetramerista glabra Miq. & Punah & $*$ \\
\hline Theaceae & Schima superba Gardn. \& Champ. & Samak, Puspa & 24166 \\
\hline Thymelaeaceae & Gonystylus sp. & Ramin & * \\
\hline
\end{tabular}




\section{INTRODUCTION TO KEY FEATURES}

The following section presents the main characters used in the descriptions of the individual wood species.

\section{Shape of the vessel elements}

The vessel elements are basically tubes that can be divided into three types. The shape of the vessel body (not considering the tails) resembles that of a "drum", a "barrel", or a "tube", terms used in the descriptions of the wood species. Some species possess vessel elements of one type, others vessel elements of various types.

If the ratio of length to width is $\leq 1$ the vessel element is designated drum-shaped (Fig. 1A).

If the ratio ranges from 1 to 2 , the vessel element is designated barrel-shaped (Fig. 1B).

If the ratio is $\geq 2$, the vessel element is designated tube-shaped (Fig. 1C).

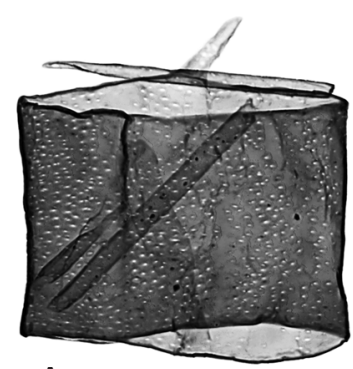

A

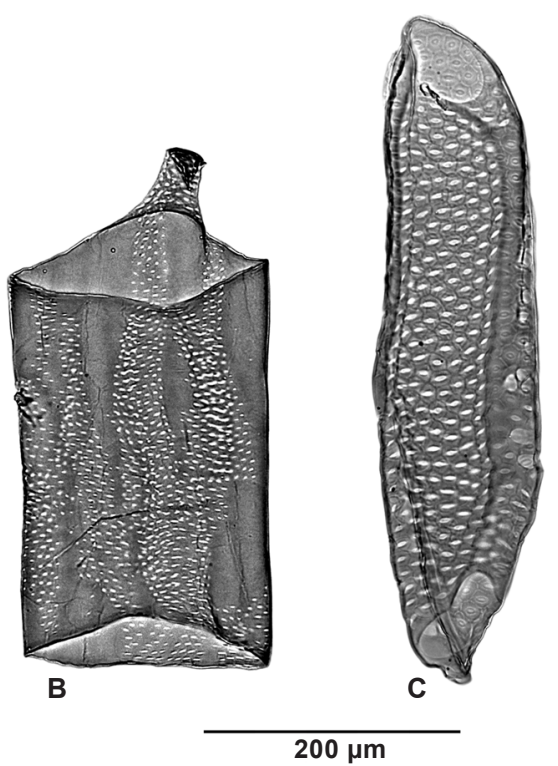

Figure 1. Shape of the vessel elements.

A: drum-shaped (Albizia procera, ratio length/width =0.8. - B: barrel-shaped (Acacia mangium, ratio $1 / \mathrm{w}=1.7$. - C: tube-shaped (Swintonia $\mathrm{sp}$., ratio $1 / \mathrm{w}=3.5$ ). 


\section{Tails}

The vessel elements frequently possess tails at the top and/or the bottom. The transition from the more or less cylindrical vessel element body to the tail can be abrupt (Fig. 2A) or gradual (Fig. 2B).

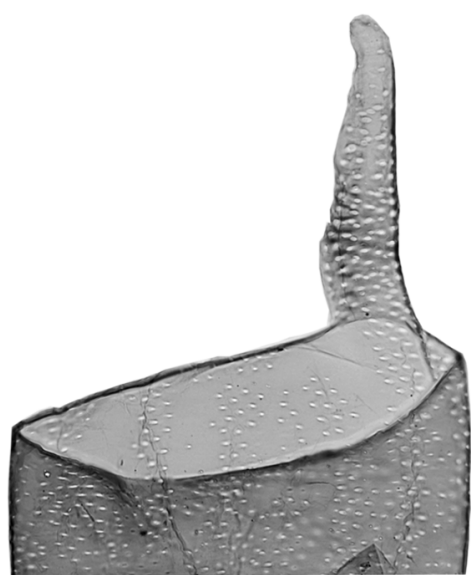

A

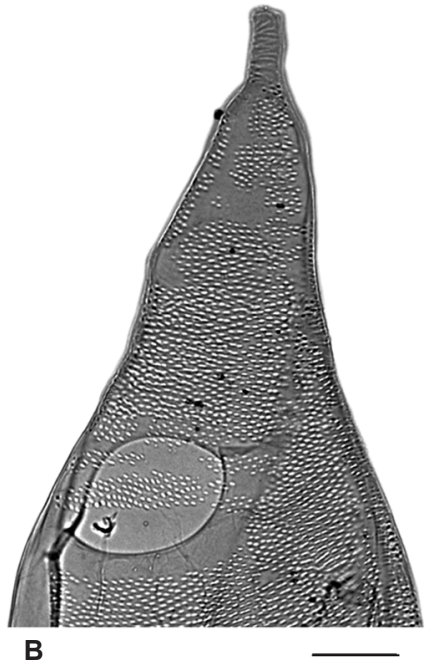

$\overline{100 \mu \mathrm{m}}$

Figure 2. Tails.

A: with abrupt transition, Albizia procera. - B: with gradual transition and laterally positioned perforation plate, Lophopetalum sp. 


\section{Perforation plates}

Perforation plates are mainly located at both ends of the vessel elements, sometimes positioned laterally (Fig. 2B).

The perforation plates can be simple (a perforation with a single circular or elliptical opening, Fig. 3 A, C and D), or scalariform (a perforation plate with parallel openings separated by one to many mainly unbranched bars, Fig. $3 \mathrm{~B}$ ). The opening can comprise the entire lumen (Fig. $3 \mathrm{~A}-\mathrm{C}$ ) or can be narrowed (of a lesser diameter, adapted to the vessel end taper, Fig. 3 D).

Perforations can be horizontal (extending over the entire diameter and more or less perpendicular to the longitudinal axis (Fig. $3 \mathrm{~A}$ ) or inclined and elongated (Fig. $3 \mathrm{E}$ and $\mathrm{F}$ ). The shape of vessel elements with inclined endings reminds of a parallelogram (inclination at vessel tips parallel, Fig. 3E) or a trapezium (inclination of vessel ends in opposite directions, Fig. 3F). Both conditions often occur within the same species.

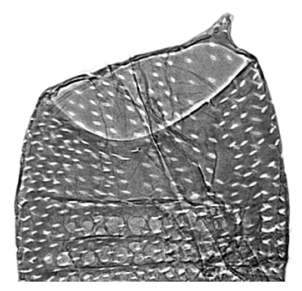

A

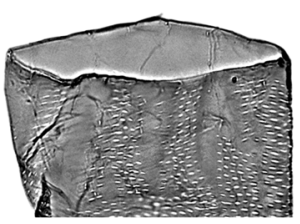

C

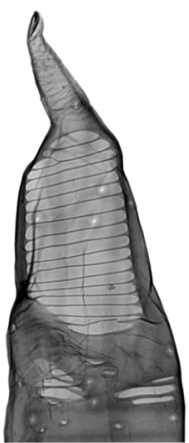

B

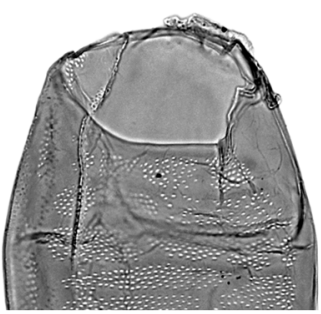

D
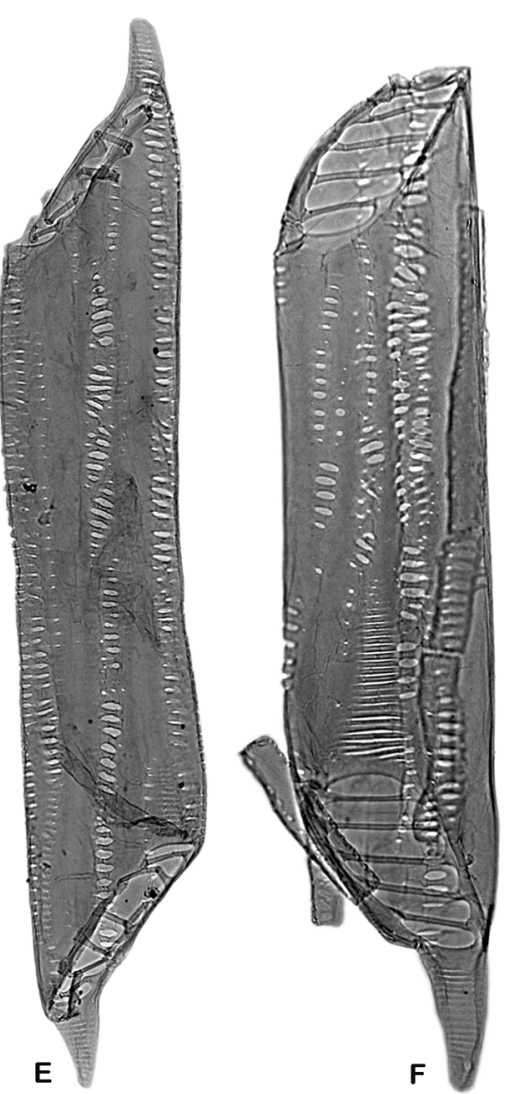

Figure 3. Perforation plates as defined in this atlas.

A: simple: Eucalyptus globulus. - B: scalariform: Liquidambar formosana. - C: opening horizontal, extending over the entire lumen: Acacia mangium. - D: narrowed: Lophopetalum sp. E: inclined, parallelogram: Rhizophora sp. - F: inclined, trapezium: Rhizophora sp. 


\section{Pit types}

The different pits constitute an important feature for wood identification. The fiber atlas of Ilvessalo-Pfäffli (1995) includes descriptions of the different pit types and their arrangements on vessel elements. It should be noted that the pit types are sometimes difficult to distinguish.

Intervessel pits are the connections between adjacent vessel elements. They can be recognized due to their arrangement in large fields. The arrangement can be alternate (arranged in diagonal rows), opposite (arranged in short to long horizontal rows, i.e., rows orientated transversely across the length of the vessel) or scalariform (elongated or linear intervessel pits arranged in a ladder-like series, Fig. 4; IAWA Committee 1989). Within one species they have the same size range, a combination of features important for the identification of the timbers. The pit apertures can be circular to oval (Fig. 5A), slit-like (Fig. 5B) or coalescent (Fig. 5C, connecting several pits across their borders).

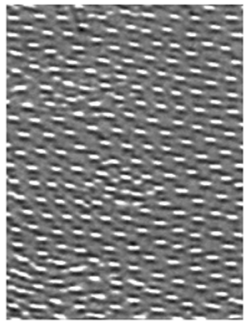

A

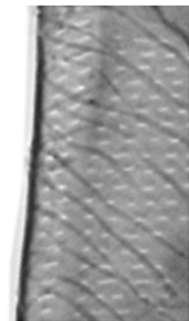

B

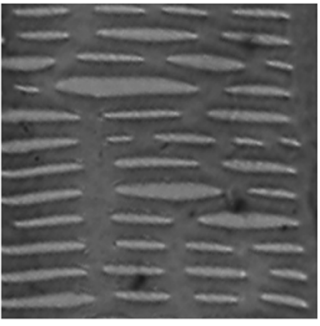

C

$50 \mu \mathrm{m}$

Figure 4. Arrangement of intervessel pits.

A: alternate, Lophopetalum sp. - B: opposite, Ilex triflora. - C: scalariform, Nyssa javanica.

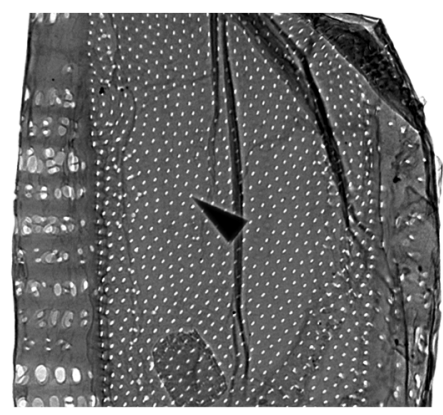

A

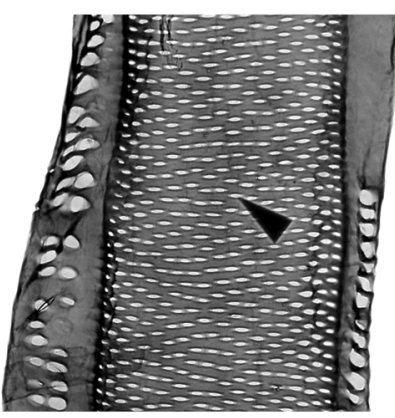

B

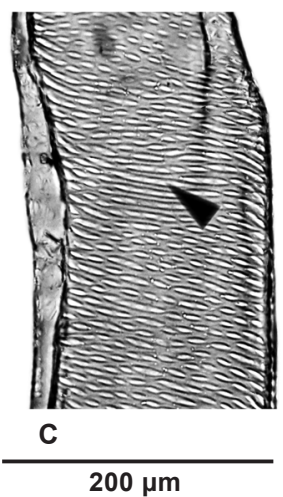

$200 \mu \mathrm{m}$

Figure 5. Intervessel pit apertures.

A: circular to oval, Syzygium dyerianum. - B: slit-like, Canarium sp. - C: coalescent, Hevea brasiliensis. 
Vessel-ray pits connect vessel elements with ray parenchyma cells. They are arranged in horizontal rows, often several rows per ray cell. Vessel-ray pits are either similar in size and shape to intervessel pits or different. The species group possessing similar pits is denominated APS (All Pits Similar in size and shape) (see p. 272, Hardwoods with simple perforations).

The group of species with vessel-ray pits differing in appearance and morphology from intervessel pits is denominated VAS in this atlas (see p. 296 in the introductory comments to the species group VAS (Vessel-ray pits Apparently Simple)). They have much reduced borders, the apertures are elongated or window-like, small or large, circular or angular, extended horizontally ('gash-like') or vertically ('palisade'). Various combinations of vessel-ray pit features may occur within one species (Fig. 6A-C).

Pits to axial parenchyma cells are the connections between vessel elements and contact axial parenchyma cells. They usually resemble vessel-ray parenchyma pits and often form brick-like pit fields reflecting the outline of the respective parenchyma cells (Fig. 6A and D).

Pits to fibers are the connection between vessel elements and fibers. They are arranged in single vertical rows (Fig. 6A) and are rarely present.

Pits to tracheids connect vessel elements with tracheids. They are usually similar to intervessel pits in size and shape and are arranged in one to several, sinuous or straight vertical strips (Fig. 6 A and C).
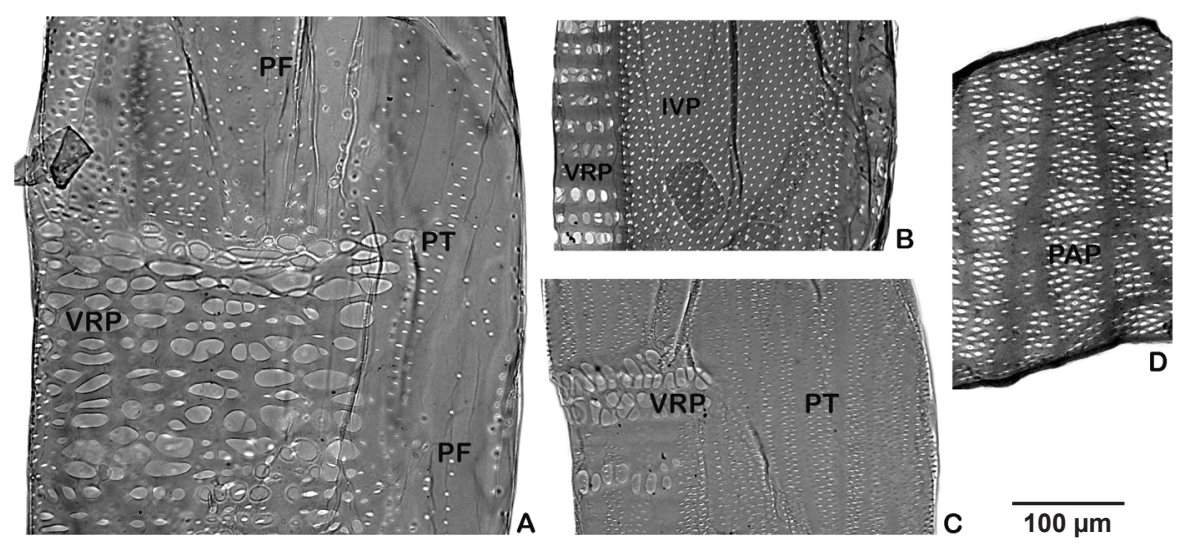

Figure 6. Pit type.

Vessel-ray pits (VRP), pits to axial parenchyma cells (PAP), pits to fibers (PF), pits to tracheids (PT), intervessel pits (IVP).

A: Dipterocarpus sp. - B: Syzygium dyerianum. - C: Calophyllum sp. - D: Paulownia tomentosa. 


\section{Areas without any pits}

Some vessel elements possess very large (Fig. 7A) or large areas without any pits (Fig. 7, arrow in B), some have small areas (Fig. 7, arrowhead in B). Areas devoid of pits may also be absent (Fig. 7C).

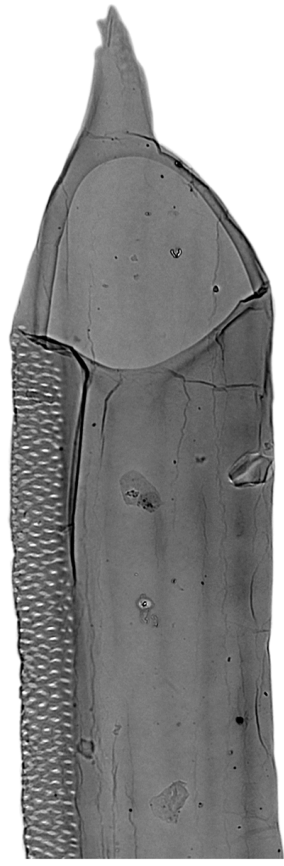

A

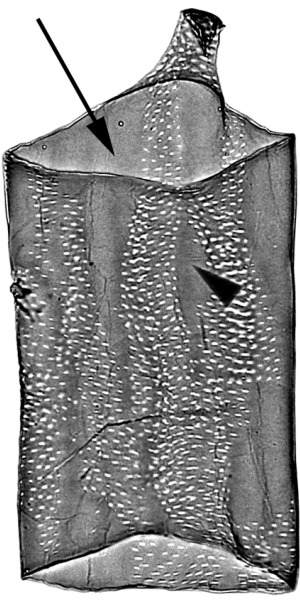

B

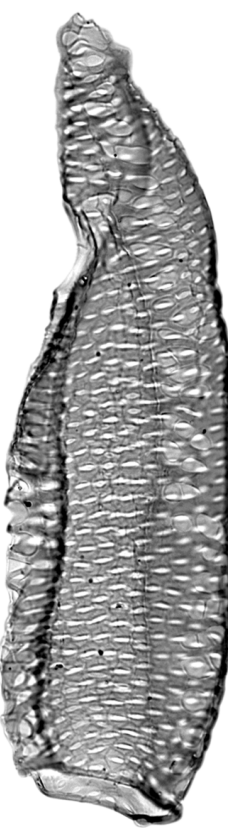

C

$200 \mu \mathrm{m}$

Figure 7. Areas without any pits.

A: very large, Campnosperma sp. - B: large (arrow), small (arrowhead), Acacia sp. - C: absent, Swintonia sp. 


\section{Tyloses}

Certain wood species generate tyloses in the heartwood (Fig. 8A), less frequently also in the sapwood. Tyloses are outgrowths from an adjacent ray or axial parenchyma cell through a pit in a vessel wall, partially or completely blocking the vessel lumen. They constitute a feature which should only be used in a positive sense, i.e. if present. If they are absent the material studied may consist entirely of sapwood of a species capable of forming tyloses in the heartwood, or else the species in question does not produce tyloses. It is also possible that tyloses may be removed from the vessel elements during the pulping process.

Certain wood species can also contain tyloses due to compartmentalisation of damage in the tree after wounding (Schmitt \& Liese 1994 and Liese 1995; Dujesiefken $\&$ Liese 2008) when normal wood does not form tyloses. Normal sapwood may also contain tyloses in embolized vessels (De Micco et al. 2016).

\section{Helical thickenings}

Some wood species possess helical thickenings (ridges on the inner face of the vessel element wall in a roughly helical pattern) throughout the vessels or restricted to the tails (IAWA Committee 1989). Helical thickenings are not removed during pulping (Fig. 8B and C).

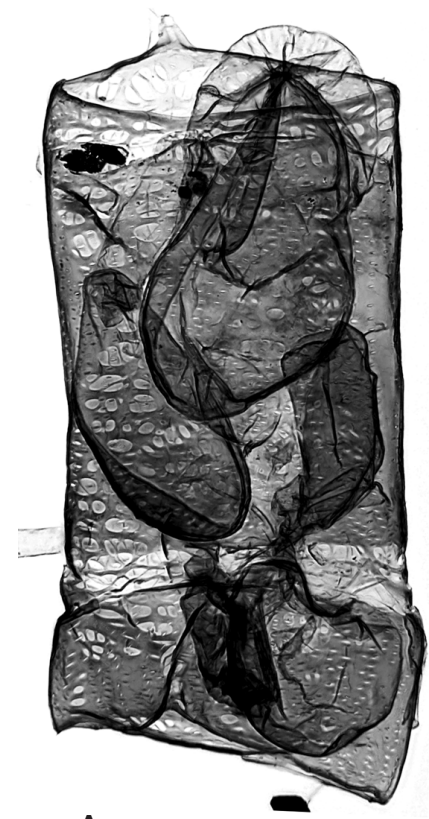

A

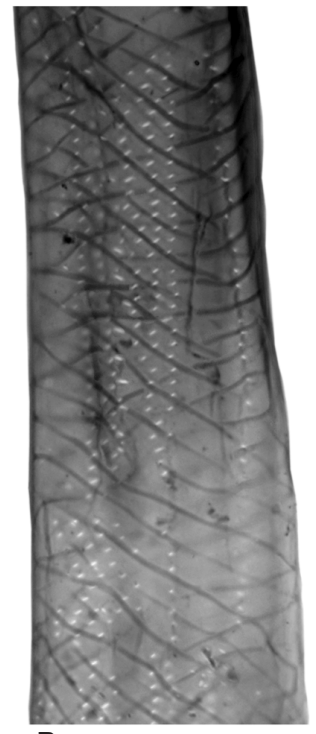

B

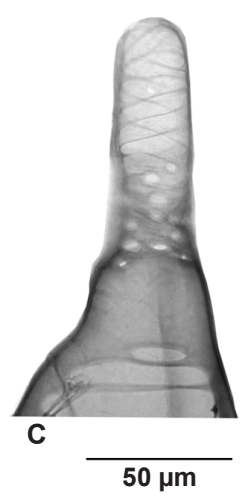

Figure 8. Tyloses and helical thickenings.

A: tyloses, Castanopsis sp. - B: helical thickenings in vessel elements, Ilex triflora var. kanehirai. - C: helical thickenings in vessel element tails, Liquidambar formosana; scale $50 \mu \mathrm{m}$ is valid for $\mathrm{B}$ and $\mathrm{C}$. 


\section{Dimensions of vessel elements}

The dimensions of the vessel elements were determined as illustrated in Figure 9 (software: cellSens, Olympus Soft Imaging Solutions GmbH, Münster, Germany). At least 36 vessel elements of each species were measured (length, width $[\mu \mathrm{m}]$ ).

Element length was measured excluding the tails, according to conventions maintained in Hamburg, despite international recommendations to include the tails in the length measurements (IAWA Committee 1989). In pulp, we often found the tails to be damaged. Vessel width in macerations probably corresponds most closely to radial vessel diameter. Note that our quantitative data for vessel width are often substantially higher than vessel diameters reported in the wood anatomical literature. This may be due to the flattening of macerated vessels in microscopic slides. Furthermore, the vertical dimensions $[\mu \mathrm{m}]$ of pit apertures and borders were determined.

Vessel and pit dimensions are helpful when identifying an unknown species. They must be seen as guidelines, not as absolute values due to the variability of the species. Please note that the vertical dimensions of the pit borders may deviate from horizontal diameters given in most wood anatomical descriptions in the literature (of alternate pits only; cf. IAWA Committee 1989 and InsideWood 2004-onwards).
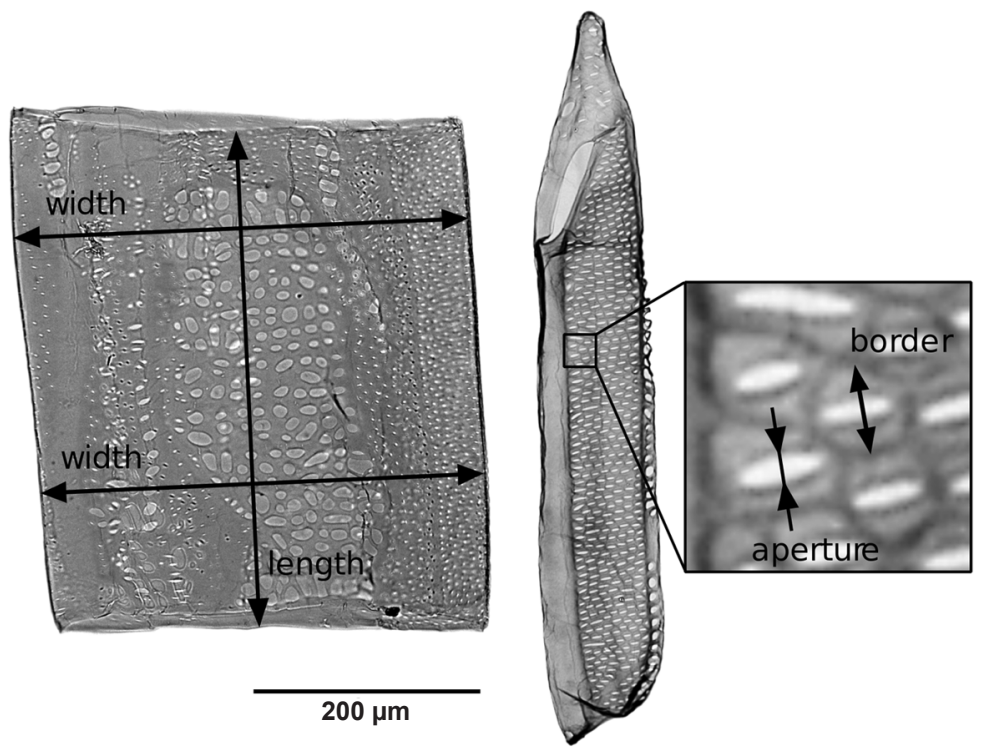

Figure 9. Measurement of vessel elements (length, width, vertical intervessel pit aperture and pit border size $[\mu \mathrm{m}])$. 


\section{Fiber dimensions}

The dimensions of the pulp fibers of Hardwoods were characterized morphologically with a Kajaani FiberLab ${ }^{\circledR}$ fiber analyzer. The fiber analyzer determines fiber length, fiber curl, fiber kinks, fibrillation, fractionation, and other parameters. The three important fiber characteristics length and width as well as cell wall thickness are presented in this atlas. All dimensions represent the weighted average (not the arithmetic average that is also calculated) because cell fragments, parenchyma cells and vessel elements in the pulp influence the measurement results. The length weighted average tends to reduce this influence (Nygård 2006).

Arithmetic average fiber length $[\mathrm{mm}]: \quad L(n)=\frac{\sum\left(n_{i} \cdot l_{i}\right)}{\sum n_{i}}$

Length weighted fiber length $[\mathrm{mm}]: \quad L(l)=\frac{\sum\left(n_{i} \cdot l_{i}^{2}\right)}{\sum n_{i} l_{i}}$

$l_{i}=$ average length in class $\mathrm{i}(\mathrm{i}=1 \ldots 152)$

$n_{i}=$ number of fibers in class $\mathrm{i}$

Since for Dendrocalamus latiflorus (Bamboo) the data obtained with the fiber analyzer were much lower than what we observed in the microscopes, the algorithm for length weighted average of fiber length apparently does not sufficiently reduce the influence of parenchyma cells and cell fragments. Therefore the length of fibers of Monocots was determined by measuring 90 fibers in the light microscope (software: cellSens, Olympus Soft Imaging Solutions GmbH, Münster, Germany). 


\section{DESCRIPTIONS OF WOODY ANGIOSPERMS OF TROPICAL AND TEMPERATE ASIA}

The following pages contain the descriptions and accompanying images of 38 species. For quicker orientation, the taxa are roughly divided into three groups and two subgroups in the following order:

Monocots: without vessel-ray pits; with axially oriented pit fields and lines void of pits (p. 267)

Hardwood species with (mainly) simple perforation plates (p. 272)

APS: All Pits Similar (in size and shape) (p. 272)

VAS: Vessel-ray pits Apparently Simple (p. 296)

\section{Hardwood species with exclusively scalariform perforation plates (p. 336)}

The descriptions start with two monocots, Bamboo and Coconut palm, followed by the group of Hardwoods with simple perforations and with two subgroups:

"APS" (All Pits Similar). Species summarized in this subgroup possess the common feature of vessel-ray and vessel-axial parenchyma pits similar to intervessel pits. The similarity refers to the size and shape of the pits.

"VAS" (Vessel-ray pits Apparently Simple). The pits of vessel elements connecting to parenchyma cells - like vessel-ray pits or pits to axial parenchyma cells - are characterized by large apertures and their borders are much reduced and not or hardly visible under the light microscope. They differ in size and shape from the intervessel pits or pits to tracheids or fibers.

The second Hardwood group contains wood species with all perforation plates scalariform. It is also possible to distinguish these species into APS and VAS but since there are only six species in this group, such a fine subdivision was deemed unnecessary.

At the beginning of each chapter of the groups and subgroups introductory comments are given about the main features characteristic of the different wood species in these groups. 


\section{Monocots \\ introductory comments}

This chapter contains two monocots: Dendrocalamus latiflorus (Bamboo) and Cocos nucifera (Coconut palm). They are included in this atlas because the material is expected to appear in paper products as an easily available resource from plantations.

As Dendrocalamus latiflorus is a grass and not a tree species it produces only a primary shoot without secondary growth (Liese 1998). There are no rays so the vascular bundles do not possess any vessel-ray pits. The vessel pits existing in vascular bundles connect with parenchyma cells or fibers.

Cocos nucifera is, like bamboo, a monocot. There is no secondary growth. The vascular bundles include very long vessel elements. They are by far the longest included in this atlas (Fig. 10a). The vessel pits present in the vascular bundles connect with adjacent parenchyma cells or fibers or with other metaxylem vessels.

Figure 10 shows the variation of vessel element length and width of the two monocots as well as the diameter of the apertures and borders of intervessel pits. The length of the vessel elements shows a significant difference whereas the width is similar and overlapping.
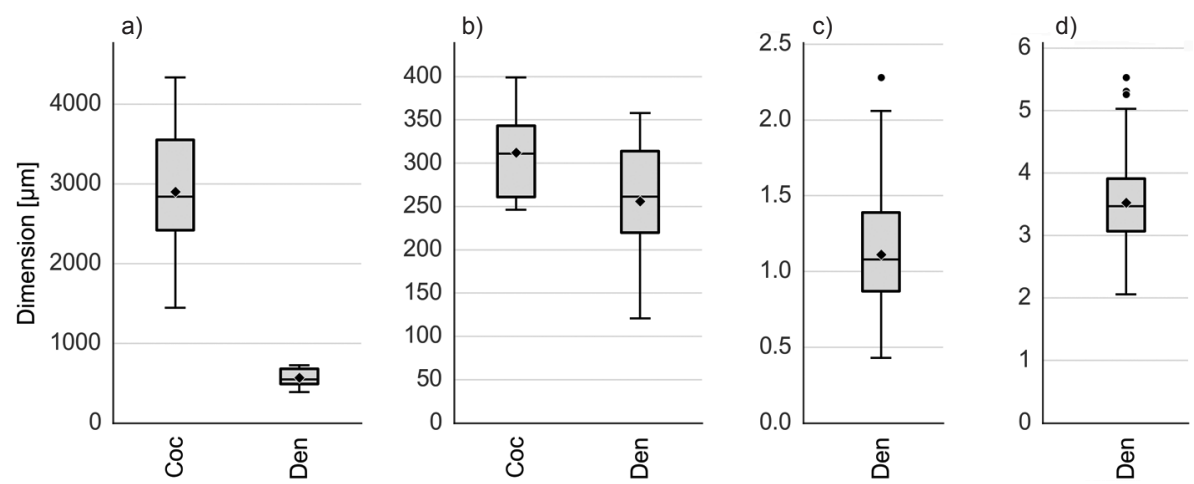

Figure 10. Boxplots of Cocos nucifera (Coc) and Dendrocalamus latiflorus (Den).

a) length and b) width of the vessel elements, c) diameter of pit apertures and d) borders; aperture and border sizes of the pits of Cocos nucifera are missing in this figure because scalariform pits can be deformed in macerations or pulp (p.271). 

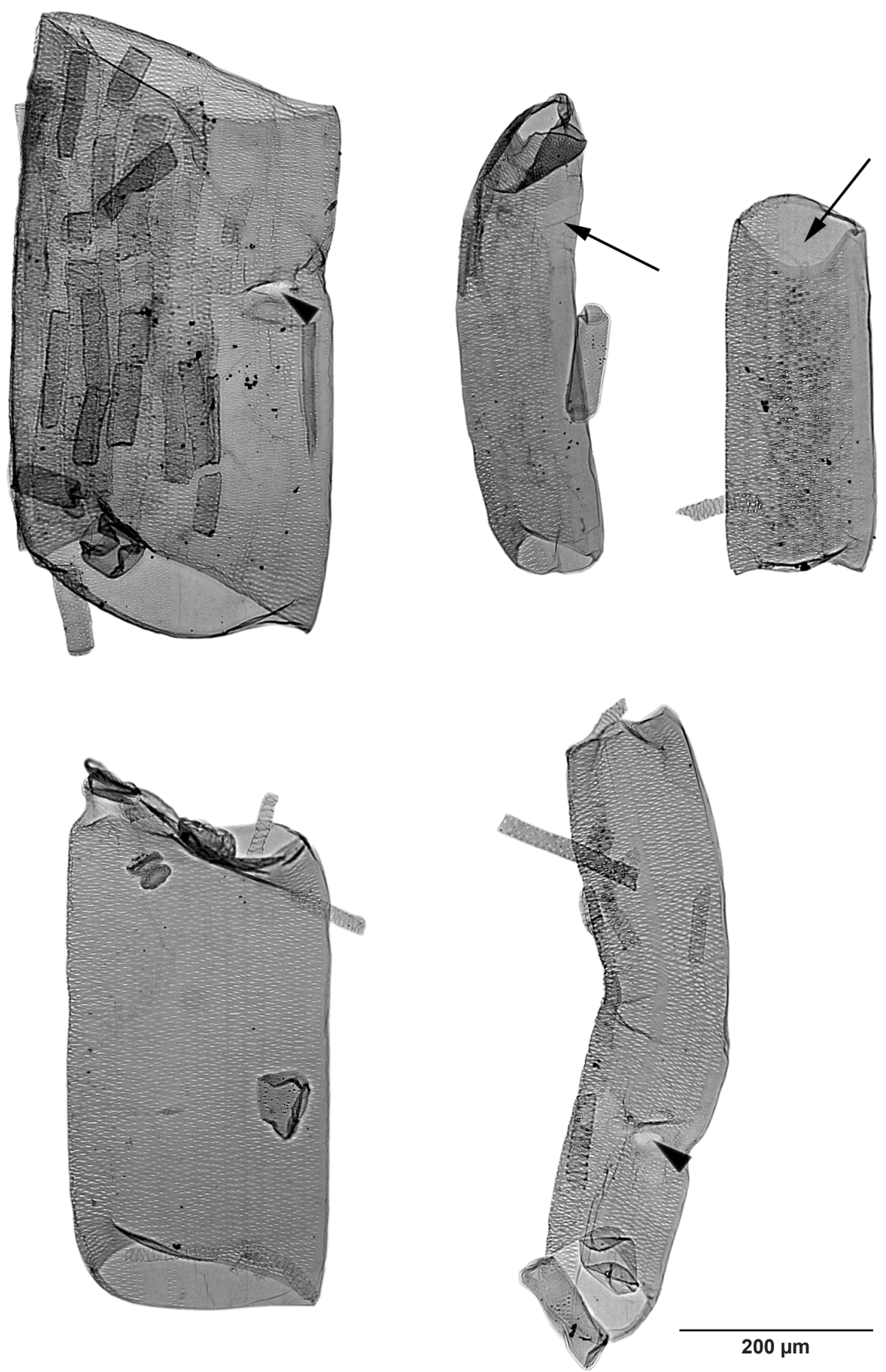

Dendrocalamus latiflorus 


\section{Dendrocalamus latiflorus Munro (Poaceae)}

Trade names: bamboo, Taiwan giant bamboo.

DIN EN 13556:2003 code: not listed.

CITES regulations: not protected.

Geographic distribution: from Myanmar to Southern China and Taiwan; cultivated in India, Thailand, Vietnam, Philippines and Japan.

Dendrocalamus latiflorus, a monocot; culms consist of parenchyma cells (about 50\%), fibers (about $40 \%$ ) and conducting tissue (about 10\%, vessel elements included) (Liese 1997).

Vessel elements: rather long (about $550 \mu \mathrm{m}$ ), of average width (about $260 \mu \mathrm{m}$ ), either tube-shaped (those with a smaller diameter) or barrel-shaped (those with a larger diameter).

Tails: absent.

Perforation plates: simple, extending over the entire lumen; slightly inclined or horizontal.

Pits to parenchyma cells: alternate; $2-4-6 \mu \mathrm{m}$; present in large fields over a wide area; apertures slit-like.

Areas without any pits: in the cell wall areas that border fiber sheaths, oriented vertically (arrows).

Tyloses: present.

Helical thickenings: absent.

Notes on identification: Sometimes the vessel elements of Dendrocalamus spp. reveal small lateral holes due to vessel branching at the internodes (arrowheads). The vessel elements possess a similar appearance as those of wheat, corn and sugar cane with the maximum vessel element length of wheat: $1.0 \mathrm{~mm}$; corn: $0.6 \mathrm{~mm}$; sugar cane: $2.1 \mathrm{~mm}$ (according to Ilvessalo-Pfäffli 1995).

\section{Quantitative data:}

Vessel elements (388-)546(-723) $\mu \mathrm{m}$ long, and (121-) 261(-358) $\mu \mathrm{m}$ wide; $1 / \mathrm{w}$ ratio 2.3 .

Fibers (487-)1262(-2575) $\mu \mathrm{m}$ long. Fiber diameter and fiber wall thickness very variable. 

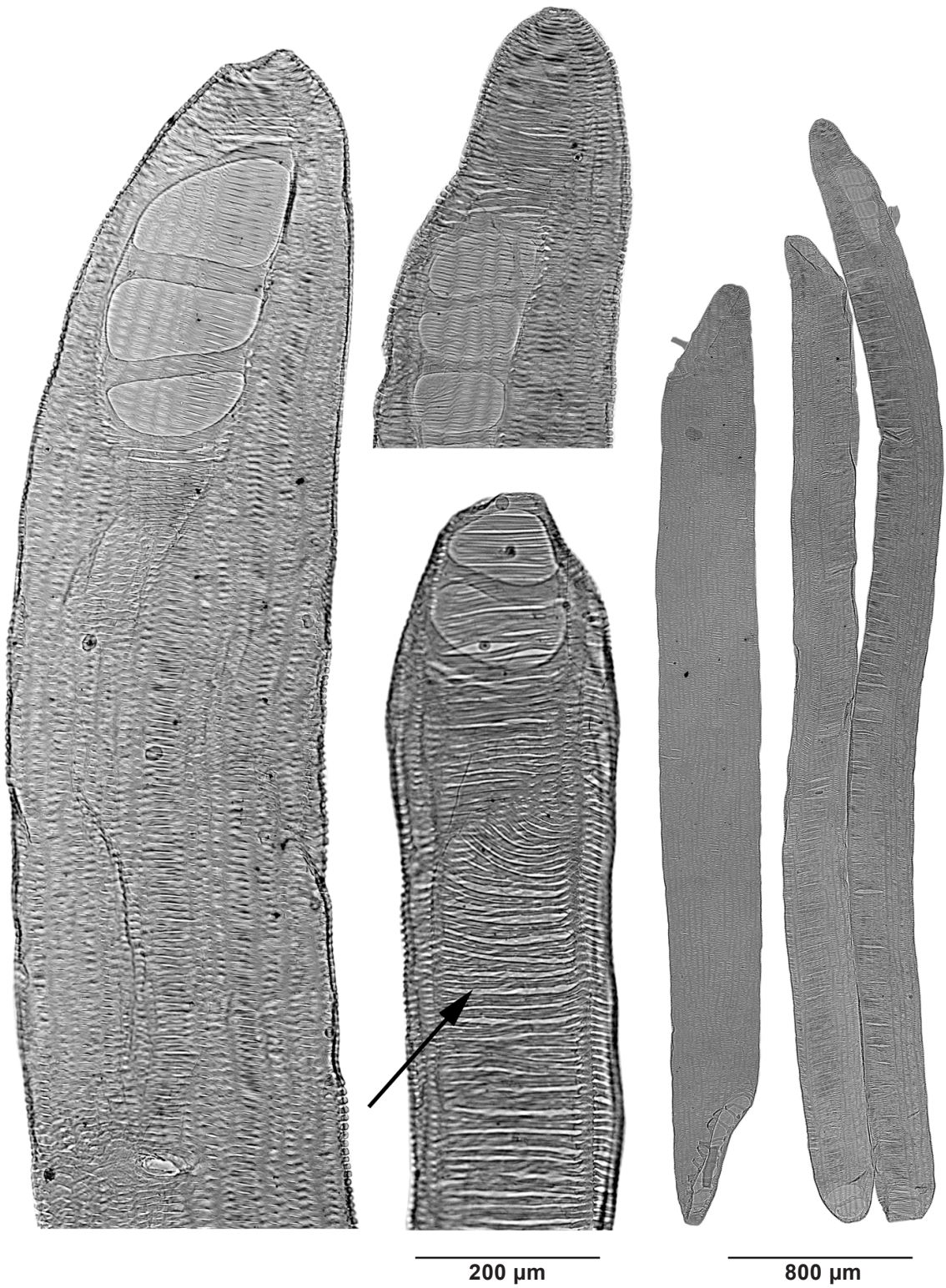

Cocos nucifera 


\section{Cocos nucifera L. (Arecaceae)}

Trade name: coconut palm.

DIN EN 13556:2003 code: not listed.

CITES regulations: not protected.

Geographic distribution: Tropics worldwide. Widely cultivated.

Cocos nucifera, a palm tree, is a monocot. The stems are built up of vascular bundles (vessels, fibers, parenchyma, phloem) embedded in ground tissue parenchyma.

Vessel elements: very long (about $2840 \mu \mathrm{m}$, width about $310 \mu \mathrm{m}$ ), much longer than vessel elements in dicotyledons, tube-shaped.

Tails: absent.

Perforation plates: scalariform with few and very thick bars (2-4 bars), inclined.

Intervessel pits: scalariform (arrow), with slit-like apertures.

Pits to parenchyma cells: apertures oval to slit-like.

Areas without any pits: absent.

Tyloses and helical thickenings: absent.

\section{Quantitative data:}

Vessel elements (1447-)2840(-4334) $\mu \mathrm{m}$ long and (246-)311(-399) $\mu \mathrm{m}$ wide; $1 / \mathrm{w}$ ratio 8.4 (contrary to the descriptions of the other species, the apertures and borders of the pits of Cocos nucifera are missing in the data because the apertures can be deformed in macerations or pulp).

Fibers (1151-)2646(-4358) $\mu \mathrm{m}$ long. Fiber diameter and fiber wall thickness very variable. 


\section{Hardwoods with simple perforations}

"APS" (All Pits Similar in size and shape) - introductory comments

The eleven wood species described in the following chapter possess the common feature of similar pits. All pit types in the vessel walls are similar in size and shape. The vessel-ray and vessel-axial parenchyma pits have the same appearance and size as the intervessel pits but their grouping may be different. In many cases the vessel-ray pits can be detected due to their specific arrangement in horizontally oriented pit areas separated by pitless zones (due to cell walls perpendicular to the vessel wall), e.g. Acacia sp., while the intervessel pits are arranged in continuous fields or areas (Figure 11).

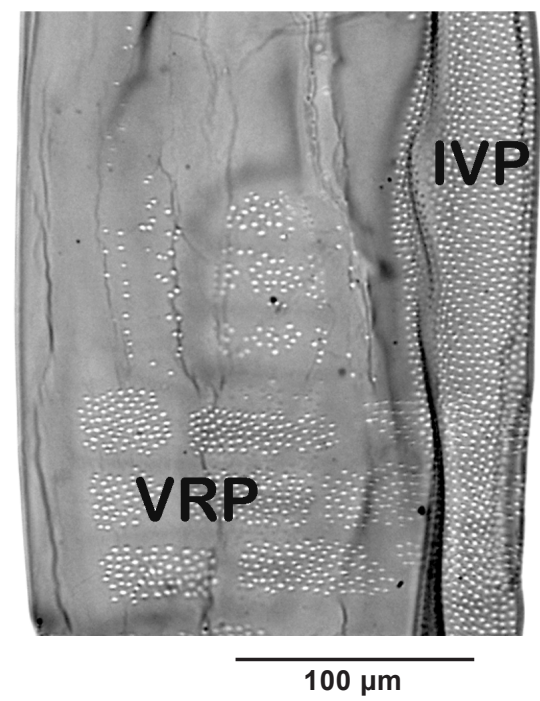

Figure 11. Similarity in size and shape of vessel-ray pits (VRP) and intervessel pits (IVP), Lophopetalum sp. 
Figure 12 shows the variation of the vessel element parameters length and width as well as the diameter of the apertures and borders of intervessel pits. The boxplots show how variable the dimensions of the different species can be.

Tetramerista glabra possesses the longest vessel elements in this group. At the same time it reveals the smallest pit apertures. This is a useful combination well-suited for identification and illustrates the potential importance of the quantitative data. However, more specimens per species should be measured for using the quantitative features as robust diagnostic characters.
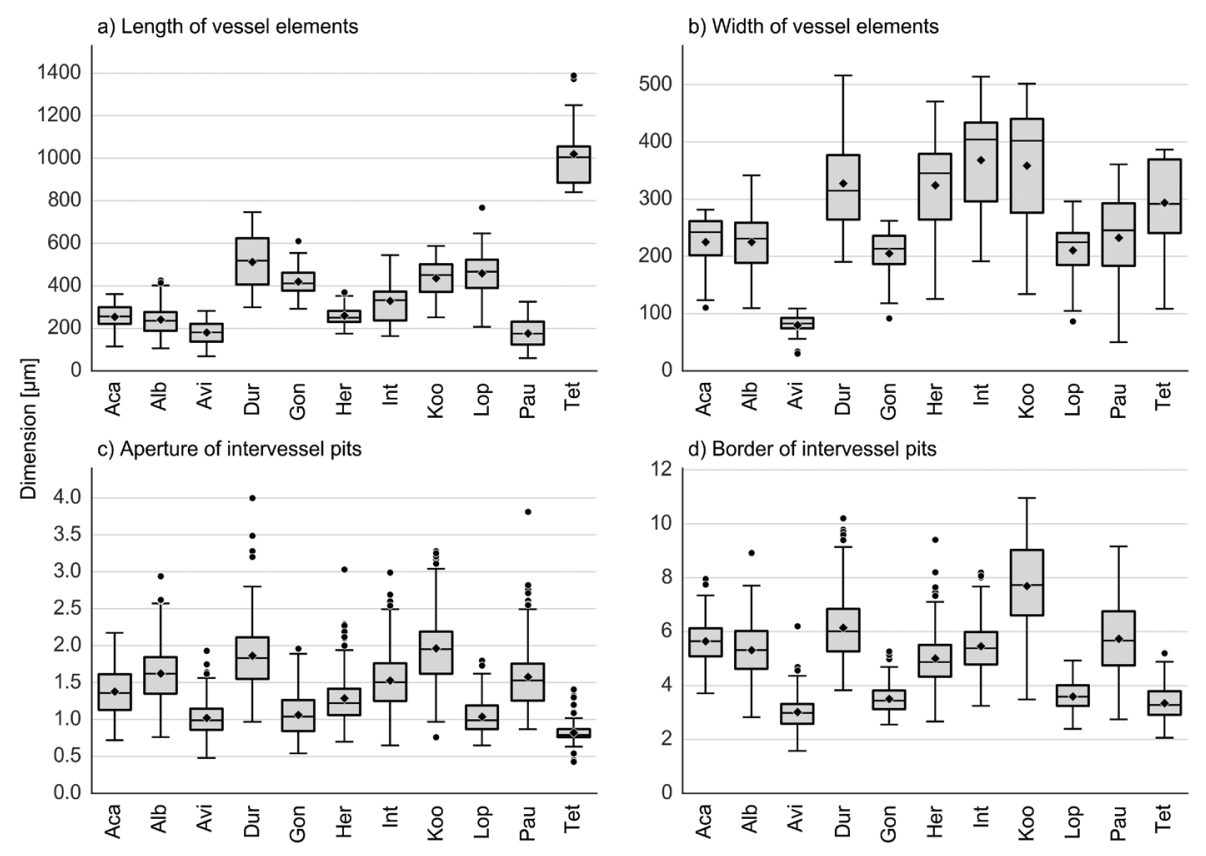

Figure 12. Boxplots of 11 wood genera/species: length and width of the vessel elements, diameter of pit apertures and borders.

Aca $=$ Acacia mangium $;$ Alb $=$ Albizia procera $;$ Avi $=$ Avicennia marina $;$ Dur $=$ Durio sp $;$ Gon = Gonystylus sp.; Her = Heritiera sp.; Int = Intsia sp.; Koo = Koompassia malaccensis; Lop $=$ Lophopetalum sp.; Pau $=$ Paulownia tomentosa $;$ Tet $=$ Tetramerista glabra . 

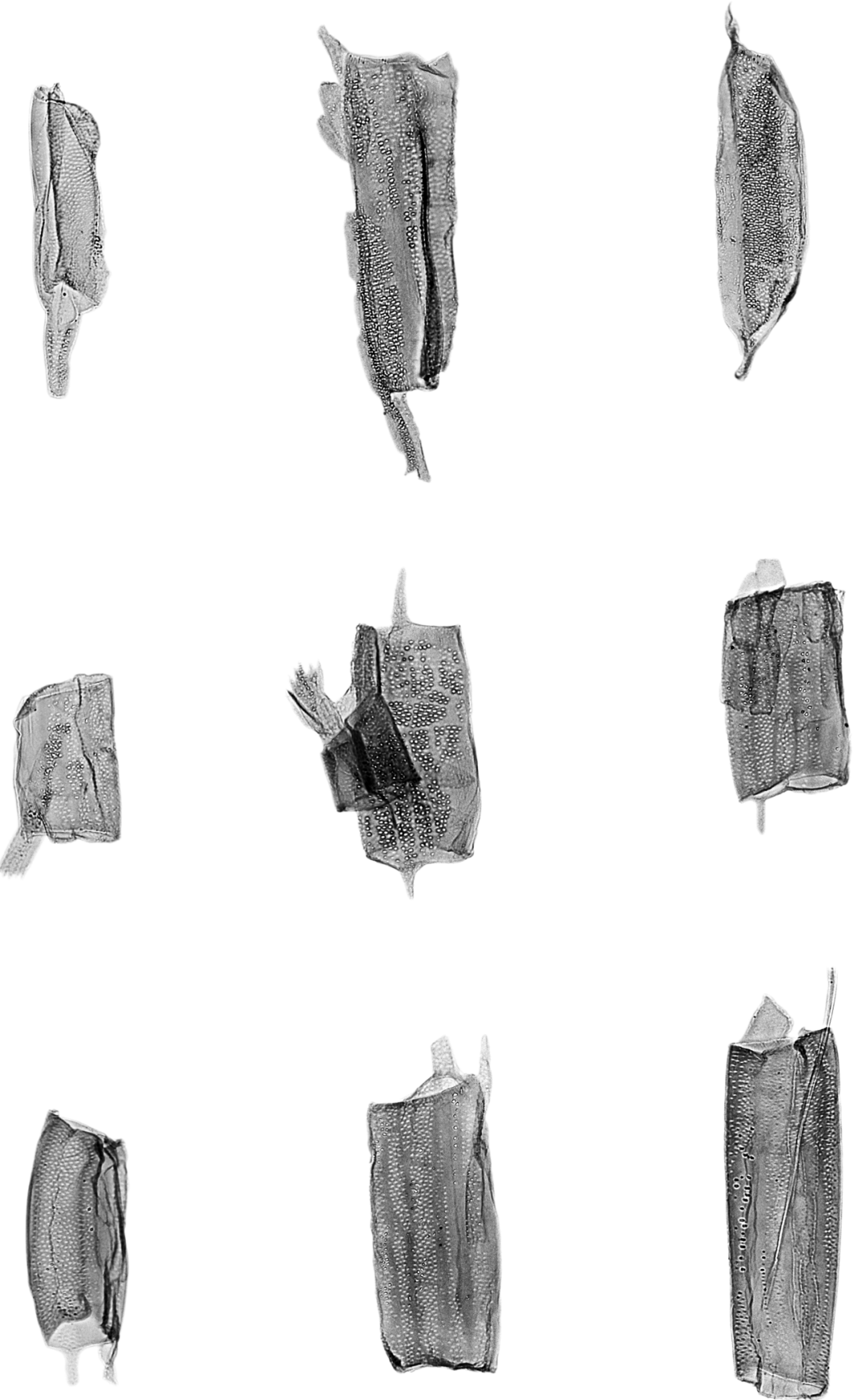

$200 \mu \mathrm{m}$

Avicennia marina 


\section{Avicennia marina (Forssk.) Vierh. (Acanthaceae)}

Trade name: api-api.

DIN EN 13556:2003 code: not listed.

CITES regulations: not protected.

Geographic distribution: throughout the Tropics.

Avicennia is a genus of mangroves.

Vessel elements: very small (length about $180 \mu \mathrm{m}$, width $80 \mu \mathrm{m}$ ), mainly barrelshaped.

Tails: often short with abrupt transition.

Perforation plates: simple, extending over the entire lumen; horizontal or inclined.

Intervessel pits: alternate; vertical diameter 2-3-6 $\mu \mathrm{m}$; present over a wide area and in the tails.

Vessel-ray pits: APS; rarely present; in horizontal rows (3-5 rows per ray cell); oval apertures.

Pits to axial parenchyma cells: numerous; in longitudinal bands or blocks comprising $3-5$ rows of pits.

Areas without any pits: present, small.

Tyloses and helical thickenings: absent.

\section{Quantitative data:}

Vessel elements (69-)180(-282) $\mu \mathrm{m}$ long, and (30-) $83(-109) \mu \mathrm{m}$ wide; $1 / \mathrm{w}$ ratio 2.3 .

Intervessel pit borders (1.6-) $3.0(-6.2) \mu \mathrm{m}$ in vertical diameter; pit apertures $(0.5-)$ $1.0(-1.9) \mu \mathrm{m}$.

Fibers $810 \mu \mathrm{m}$ long, $16.8 \mu \mathrm{m}$ wide. Fiber wall thickness $6.3 \mu \mathrm{m}$ (weighted averages). 


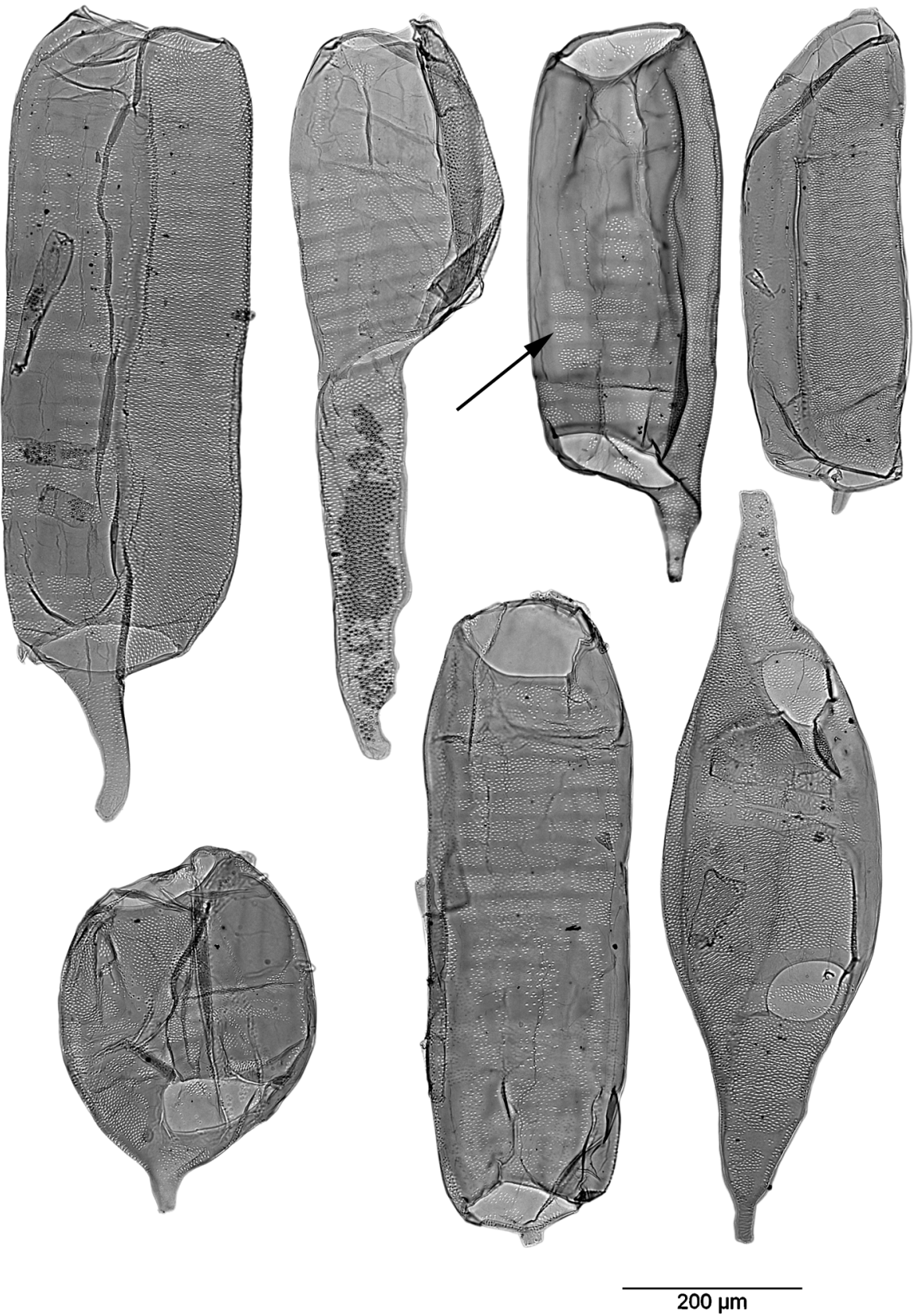

Lophopetalum sp. 


\section{Lophopetalum sp. (Celastraceae)}

Trade names: perupok, perupuk (MY, ID); adau, dual (BN); medang kerupuk, pasana (ID); abuab (PH); taung-yemaré (MM); phuamphrao, dimi, samet-thung (TH).

DIN EN 13556:2003 code: not listed.

CITES regulations: not protected.

Geographic distribution: Eastern Pakistan, Western India, Indochina and throughout Malesia; main centers of endemism are Borneo and New Guinea.

Vessel elements: average length about $470 \mu \mathrm{m}$, width about $230 \mu \mathrm{m}$; mostly rather slim (tube-shaped), sometimes shorter and "drop-shaped".

Tails: short to very long, with abrupt or gradual transition.

Perforation plates: simple; in tapering end walls; sometimes positioned laterally.

Intervessel pits: alternate; vertical diameter 2-4-5 $\mu \mathrm{m}$; present in large fields covering a wide area; apertures oval.

Vessel-ray pits: APS; often present, in long horizontal rows (6-8 rows per ray cell) separated by well-defined pitless zones (arrow).

Pits to axial parenchyma cells: present, arranged in sinuous vertical bands.

Pits to fibers: rarely present in single vertical rows.

Areas without any pits: sometimes present; large.

Tyloses and helical thickenings: absent.

Notes on identification: The vessel elements of Lophopetalum spp. are similar to those of Gonystylus spp. and Durio spp. (see Gonystylus sp., p. 294).

\section{Quantitative data:}

Vessel elements (207-)467(-767) $\mu \mathrm{m}$ long, and (87-)225(-296) $\mu \mathrm{m}$ wide; $1 / \mathrm{w}$ ratio 2.2 .

Intervessel pit borders (2.4-)3.6(-4.9) $\mu \mathrm{m}$ in vertical diameter; pit apertures (0.7-) $1.0(-1.8) \mu \mathrm{m}$.

Fibers $980 \mu \mathrm{m}$ long, $25.3 \mu \mathrm{m}$ wide. Fiber wall thickness $7.2 \mu \mathrm{m}$ (weighted averages). 

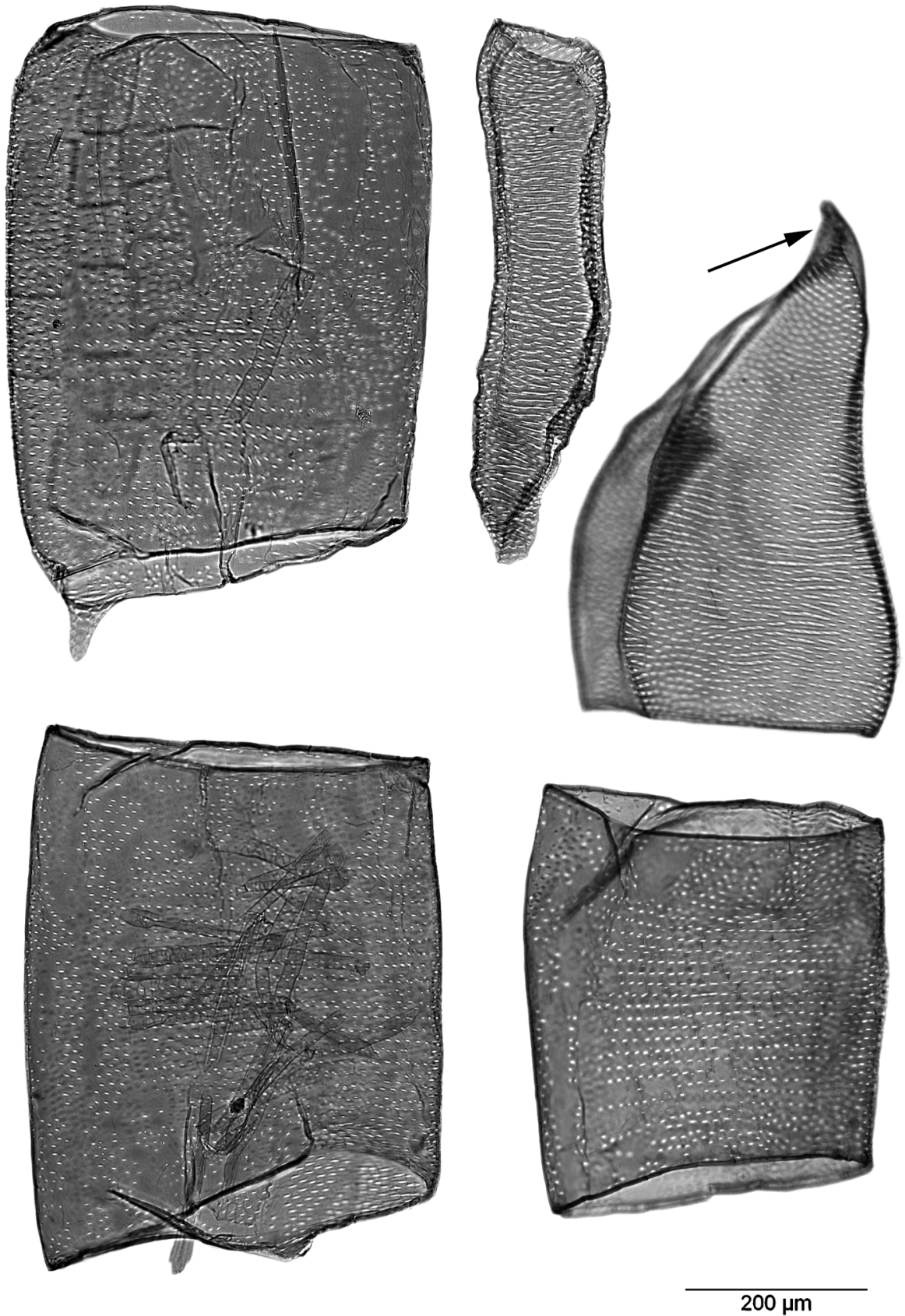

Koompassia malaccensis 


\section{Koompassia malaccensis Maingay ex Benth. (Fabaceae-Caesalpinioideae)}

Trade names: kempas (MY, ID, MY-swk, GB, NL); hampas, pah, mengris, impas, toemaling, garis, ajam (ID).

DIN EN 13556:2003 code: KOML.

CITES regulations: not protected.

Geographic distribution: Southern Thailand and Malesia (except Philippines).

Vessel elements: two size classes (length about $450 \mu \mathrm{m}$, width about $400 \mu \mathrm{m}$ ), barrel-shaped (those with a larger diameter) or tube-shaped (those with a smaller diameter).

Tails: small with abrupt transition, or absent.

Perforation plates: simple; extending over the entire lumen; horizontal, rarely inclined and pointed (arrow).

Intervessel pits: alternate; vertical diameter 4-8-11 $\mu \mathrm{m}$; present in fields, sometimes over the whole area; apertures slit-like, sometimes coalescent.

Vessel-ray pits: APS; numerous, in horizontal pattern (1-2 rows per ray cell).

Pits to axial parenchyma cells: in vertically oriented blocks.

Areas without any pits: regularly present; small.

Tyloses and helical thickenings: absent.

\section{Quantitative data:}

Vessel elements (251-)450(-588) $\mu \mathrm{m}$ long, and (134-) 402(-502) $\mu \mathrm{m}$ wide; $1 / \mathrm{w}$ ratio 1.2 .

Intervessel pit borders (3.5-)7.7(-11.0) $\mu \mathrm{m}$ in vertical diameter; pit apertures (0.8-) $2.0(-3.3) \mu \mathrm{m}$.

Fibers $1310 \mu \mathrm{m}$ long, $21.7 \mu \mathrm{m}$ wide. Fiber wall thickness $4.9 \mu \mathrm{m}$ (weighted averages). 

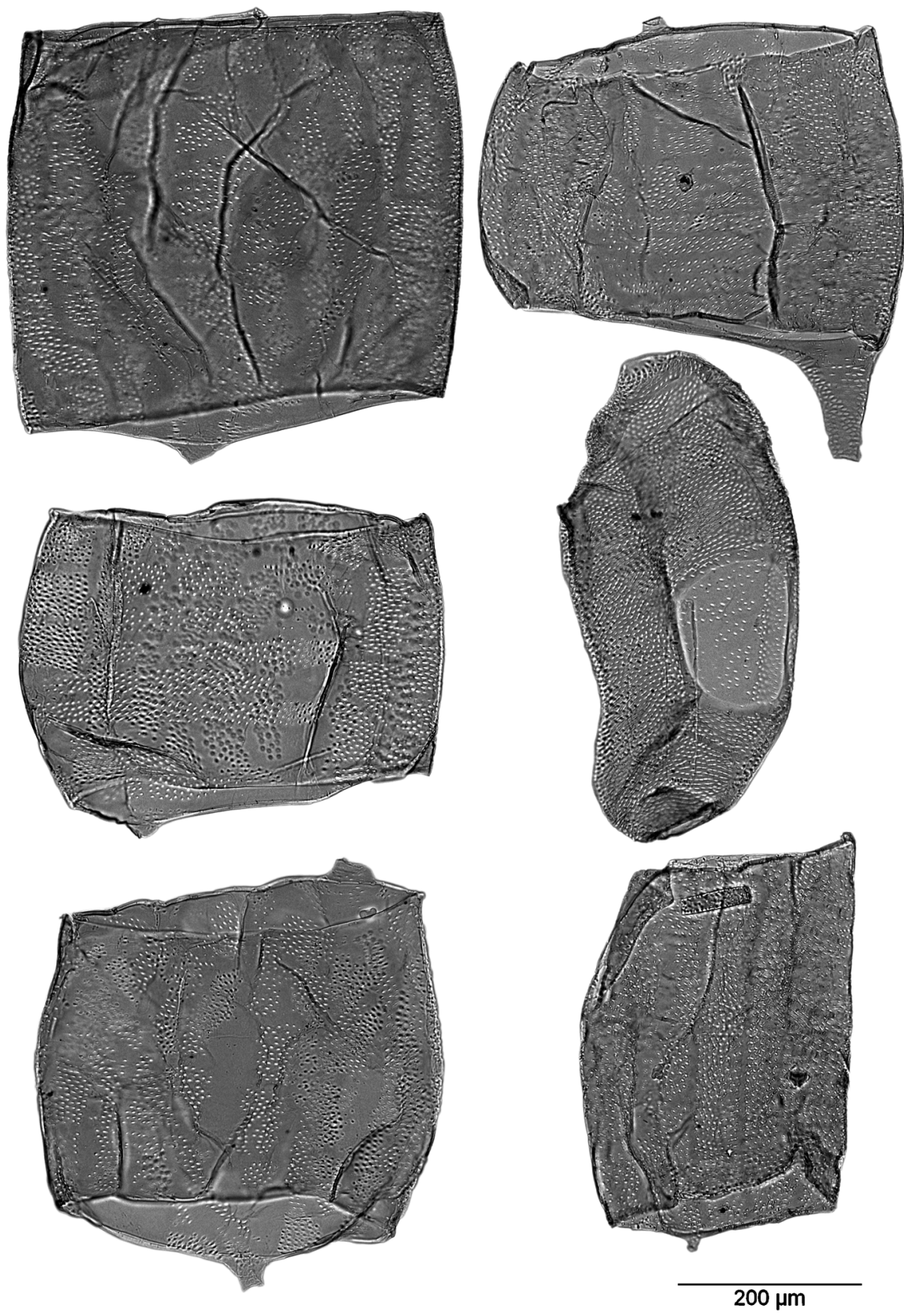

Intsia sp. 


\section{Intsia sp. (Fabaceae-Caesalpinioideae)}

Trade names: merbau (MY); Malacca teak, mirabow, Moluccan ironwood (GB); ipil, kayu besi (ID); kwila, bendora (PG); ipil, ipil laut, malaipil (PH); tat-takun (MM); krakas prak (KH); lumpho, lumpho thale (TH); hintzy (MG).

DIN EN 13556-2003 code: INXX (main species are I. bijuga and I. palembanica).

CITES regulations: not protected.

Geographic distribution: Indochina, Indomalesia, Pacific Islands, Australia, Madagascar, East Africa.

Vessel elements: rather short, but wide (length about $330 \mu \mathrm{m}$, width about $400 \mu \mathrm{m}$ ); often drum-shaped (those with a larger diameter), complemented by some barrelshaped elements (those with a smaller diameter).

Tails: rather short with abrupt transition.

Perforation plates: simple, extending over the entire lumen; rarely positioned laterally; horizontal.

Intervessel pits: alternate; vertical diameter 3-5-8 $\mu \mathrm{m}$; present over a wide area and in the tails; apertures oval.

Vessel-ray pits: APS; in 3-5 horizontal rows.

Pits to parenchyma cells: blocks arranged in sinuous longitudinal bands mirroring the parenchyma strands.

Areas without any pits: regularly present; small.

Tyloses and helical thickenings: absent.

Notes on identification: The intervessel pitting is similar to that of Acacia spp. but the vessel elements of Intsia spp. are larger in diameter.

\section{Quantitative data:}

Vessel elements (164-)333(-544) $\mu \mathrm{m}$ long, and (191-)405(-514) $\mu \mathrm{m}$ wide; $1 / \mathrm{w}$ ratio 0.9 .

Intervessel pit borders (3.2-) 5.4(-8.2) $\mu \mathrm{m}$ in vertical diameter; pit apertures (0.7-) $1.5(-3.0) \mu \mathrm{m}$.

Fibers $1590 \mu \mathrm{m}$ long, $21.9 \mu \mathrm{m}$ wide. Fiber wall thickness $5.3 \mu \mathrm{m}$ (weighted averages). 

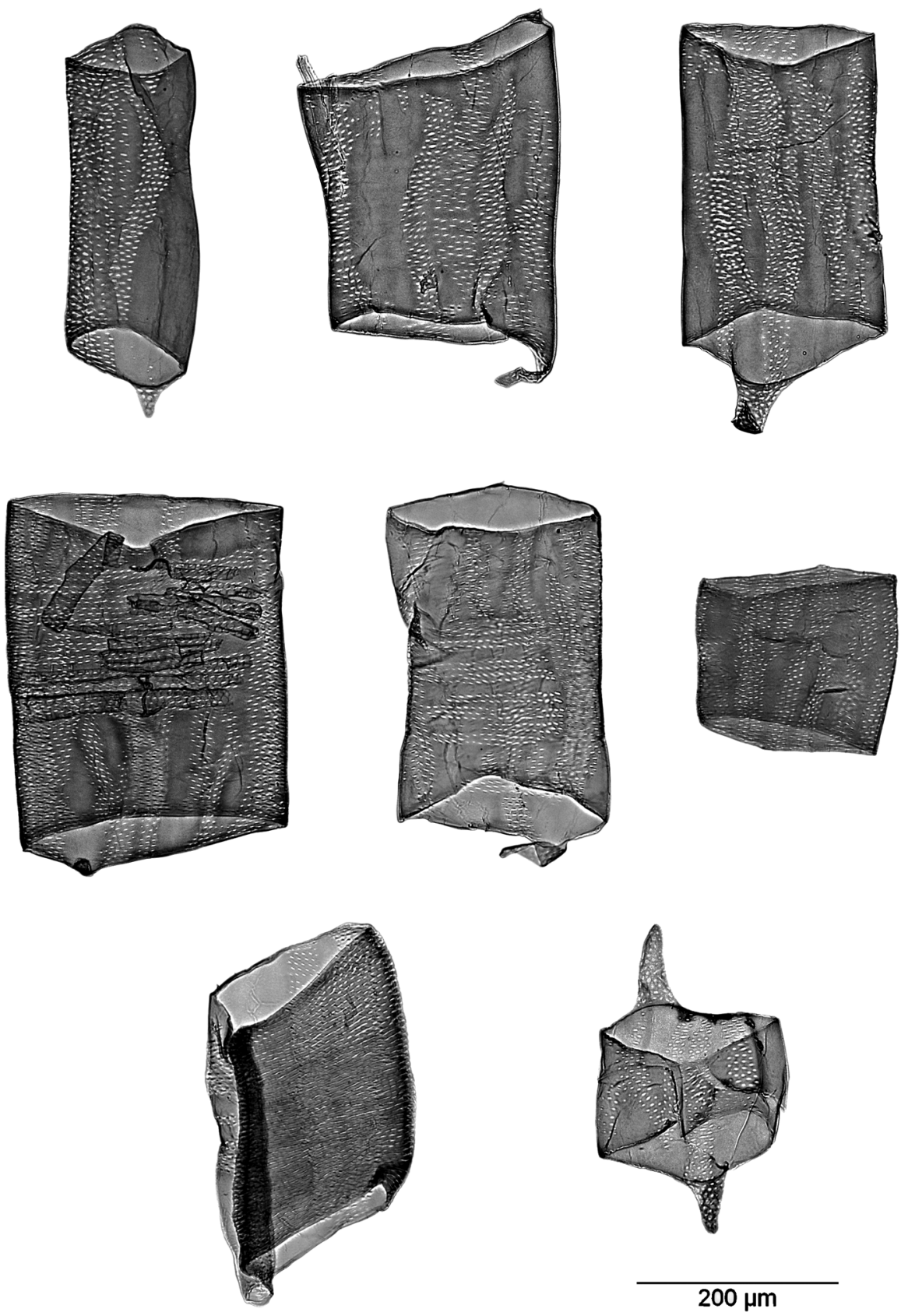

Acacia mangium 


\section{Acacia mangium Willd. (Fabaceae-Mimosoideae)}

Trade names: acasia, mangium (ID, MY).

DIN EN 13556:2003 code: not listed.

CITES regulations: not protected.

Geographic distribution: native to Australia and the Moluccan Islands; introduced in many countries, most notably in Asia (Bangladesh, China, Indonesia, Laos, Malaysia, Nepal, Philippines, Thailand, Vietnam) but also in Brazil, Cameroon, Costa Rica, Hawaii.

Acacia mangium plantations provide solid wood and short fiber raw material for the pulp and paper industry.

Vessel elements: rather small (length about $260 \mu \mathrm{m}$, width about $240 \mu \mathrm{m}$ ), often elongated (barrel-shaped), sometimes shorter (drum-shaped).

Tails: mostly short with abrupt transition.

Perforation plates: simple, extending over the entire lumen; horizontal or slightly inclined.

Intervessel pits: pits alternate; vertical diameter 4-6-8 $\mu \mathrm{m}$; rather scarce; apertures oval to slit-like.

Vessel-ray pits: APS; arranged in 2-3 horizontal rows per ray cell, separated by spaces free of pits.

Pits to axial parenchyma: frequent blocks, arranged in sinuous longitudinal rows mirroring the parenchyma strands.

Areas without any pits: regularly present; small to large.

Tyloses and helical thickenings: absent.

Notes on identification: Vessel elements of Acacia spp. are similar in appearance to Albizia spp. (same family). The tails of Acacia spp. are shorter than those of Albizia.

The intervessel pits are rather scarce whereas the ones of Albizia spp. are regularly present.

\section{Quantitative data:}

Vessel elements (114-)256(-361) $\mu \mathrm{m}$ long, and (111-)243(-282) $\mu \mathrm{m}$ wide; $1 / \mathrm{w}$ ratio 1.0 .

Intervessel pit borders (3.7-)5.6(-8.0) $\mu \mathrm{m}$ in vertical diameter; pit apertures (0.7-) $1.4(-2.2) \mu \mathrm{m}$.

Fibers $830 \mu \mathrm{m}$ long, $17.9 \mu \mathrm{m}$ wide. Fiber wall thickness $4.3 \mu \mathrm{m}$ (weighted averages). 

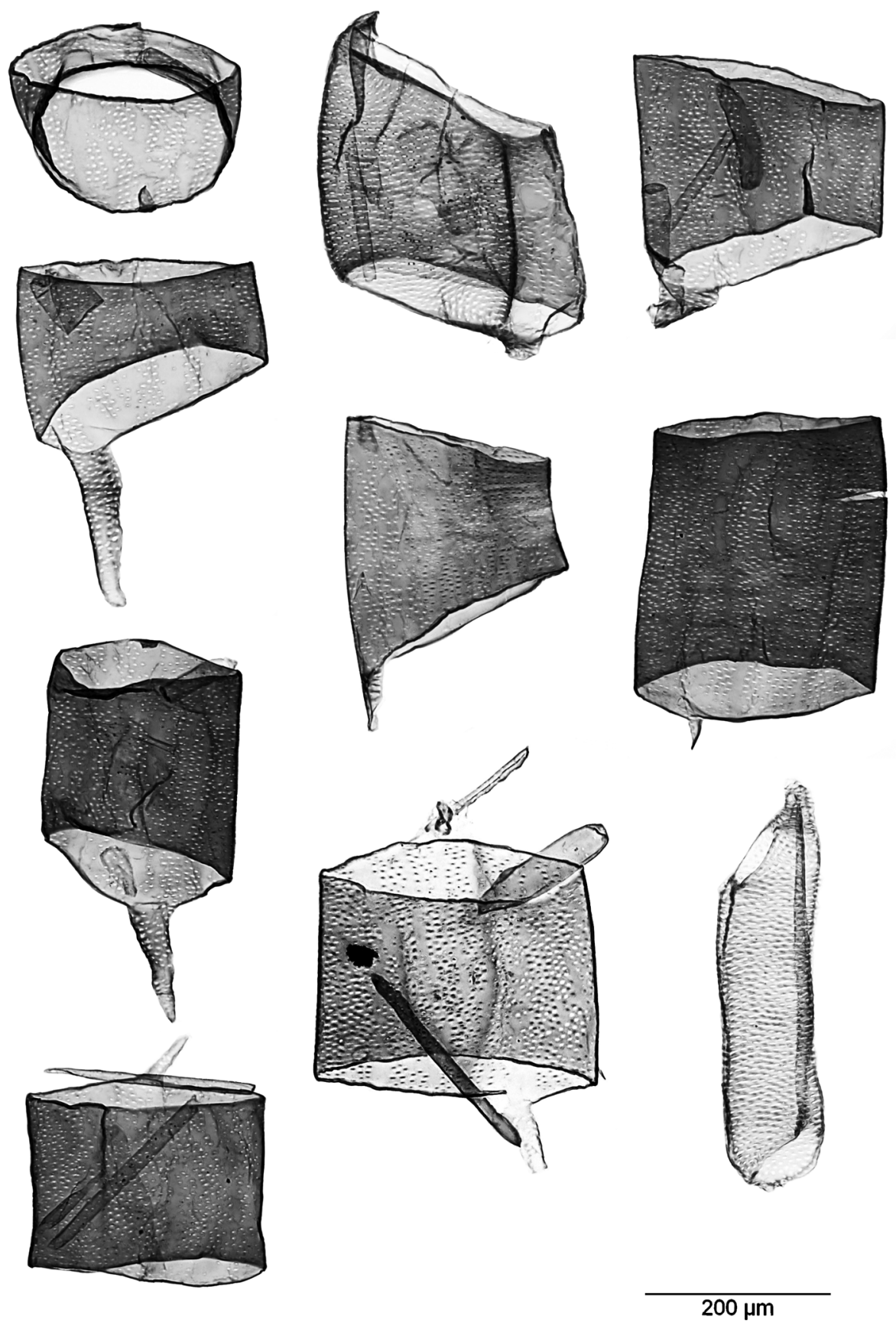

Albizia procera 


\section{Albizia procera (Roxb.) Benth. (Fabaceae-Mimosoideae)}

Trade names: tall albizia (GB); ki hiyang, wangkal, weru (ID); brown albizia (PG); akleng parang (PH); kokko-sit, sit, sitpen (MM); suan, thing thon (TH); muong xanh (VN); karangro, karak, baro, dun-siris, gurar (IN); oriang (MY); seto siris (NP); tramkang $(\mathrm{KH})$; rain siris (AU).

DIN EN 13556:2003 code: AZXX (Albizia spp.).

CITES regulations: not protected.

Geographic distribution: China, Indochina, Indomalesia, Pacific Islands, Australia.

Vessel elements: quite short (about $240 \mu \mathrm{m}$, width about $230 \mu \mathrm{m}$ ); mainly drum-shaped (with larger diameter), sometimes tube and barrel-shaped (with smaller diameter).

Tails: sometimes short to mostly rather long, with abrupt transition.

Perforation plates: simple, extending over the entire lumen; horizontal to slightly inclined.

Intervessel pits: alternate; vertical diameter 3-5-9 $\mu \mathrm{m}$; arranged in large fields, also in the tails; apertures circular to oval.

Vessel-ray pits: APS; similar to intervessel pits.

Pits to axial parenchyma cells: present in blocks (2-4 rows of pits wide) forming vertical strips.

Pits to fibers: rarely present; arranged in single vertical rows; rather small.

Areas without any pits: regularly present; small.

Tyloses and helical thickenings: absent.

Notes on identification: Vessel elements of Albizia spp. are similar to those of Acacia spp. in their appearance (same family, p. 282).

\section{Quantitative data:}

Vessel elements (106-) 235 (-426) $\mu \mathrm{m}$ long, and (110-) $231(-342) \mu \mathrm{m}$ wide; $1 / \mathrm{w}$ ratio 1.0 .

Intervessel pit borders (2.8-)5.3(-8.9) $\mu \mathrm{m}$ in vertical diameter; pit apertures $(0.8-)$ $1.6(-2.9) \mu \mathrm{m}$.

Fibers $890 \mu \mathrm{m}$ long, $23.2 \mu \mathrm{m}$ wide. Fiber wall thickness $2.3 \mu \mathrm{m}$ (weighted averages). 


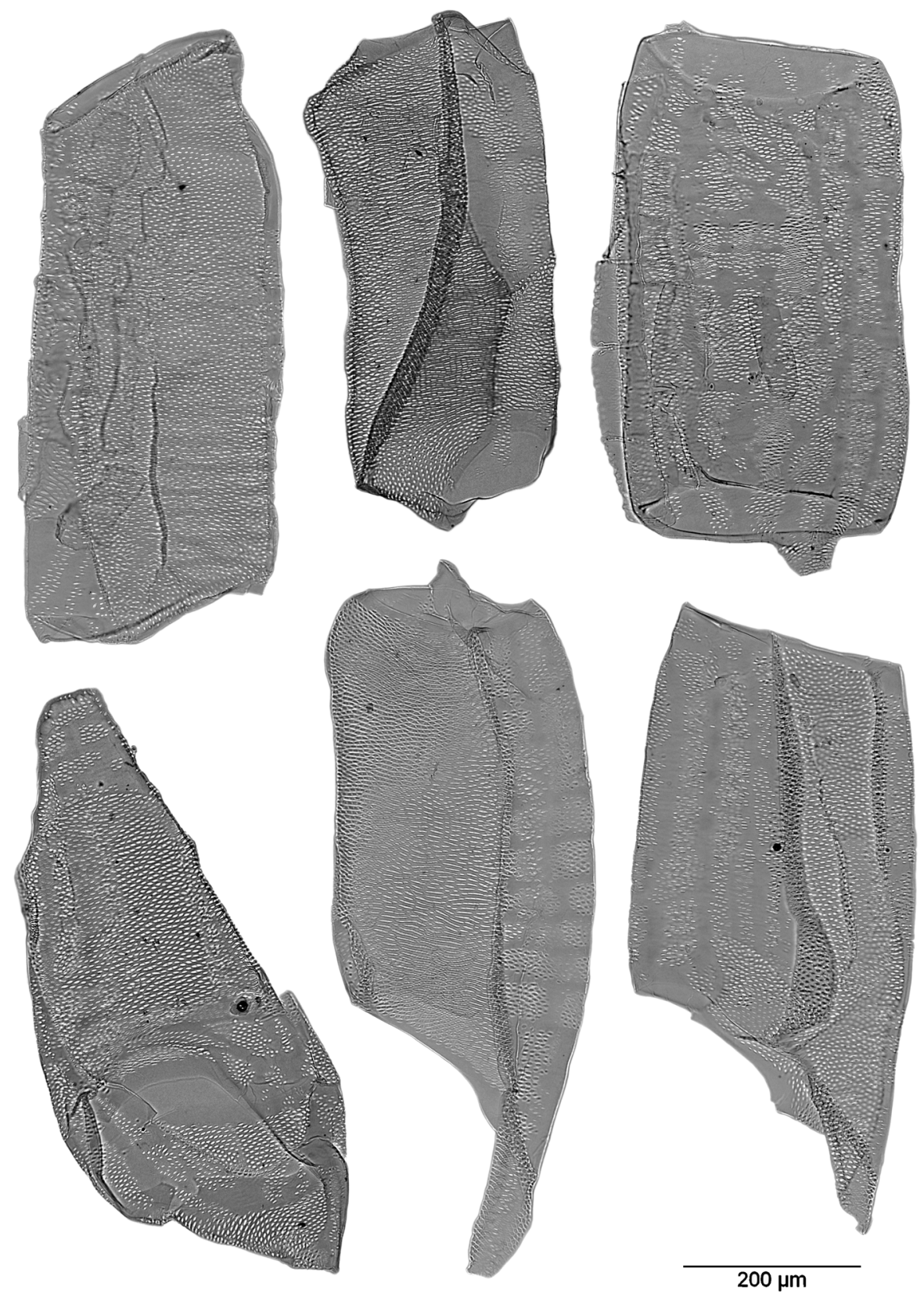

Durio sp. 


\section{Durio sp. (Malvaceae)}

Trade names: durian (DE, ID, MY); punggai, durian isa (MY).

DIN EN 13556: 2003 code: DUXX.

CITES regulations: not protected.

Geographic distribution: Indochina, Indomalesia.

Durio spp. is cultivated as plantation tree for fruit production. The wood is used for furniture or ply-wood.

Vessel elements: rather large (length about $520 \mu \mathrm{m}$, width about $320 \mu \mathrm{m}$ ), mainly barrel-shaped.

Tails: short with abrupt transition, sometimes longer with gradual transition.

Perforation plates: simple, extending over the entire lumen; horizontal or inclined.

Intervessel pits: alternate; vertical diameter 4-6-10 $\mu \mathrm{m}$; numerous; present over a wide area and in the tails; pit apertures oval to slit-like.

Vessel-ray pits: APS; cross-fields arranged in neat horizontal series with 3-6 rows of pits per ray cell.

Pits to axial parenchyma cells: cross-fields arranged in longitudinal series (3-5 pits wide) of mostly irregular outline; apertures oval to slit-like.

Areas without any pits: regularly present; small.

Tyloses and helical thickenings: absent.

Notes on identification: Vessel elements of Durio spp. are similar in appearance to those of Gonystylus spp. and Lophopetalum spp. (see Gonystylus sp., p. 294).

\section{Quantitative data:}

Vessel elements (299-)519(-746) $\mu \mathrm{m}$ long, and (191-)315(-516) $\mu \mathrm{m}$ wide; $1 / \mathrm{w}$ ratio 1.6 .

Intervessel pit borders (3.8-)6.0(-10.2) $\mu \mathrm{m}$ in vertical diameter; pit apertures (1.0-) $1.8(-4.0) \mu \mathrm{m}$.

Fibers $1375 \mu \mathrm{m}$ long, $29.4 \mu \mathrm{m}$ wide. Fiber wall thickness $8.0 \mu \mathrm{m}$ (weighted averages). 

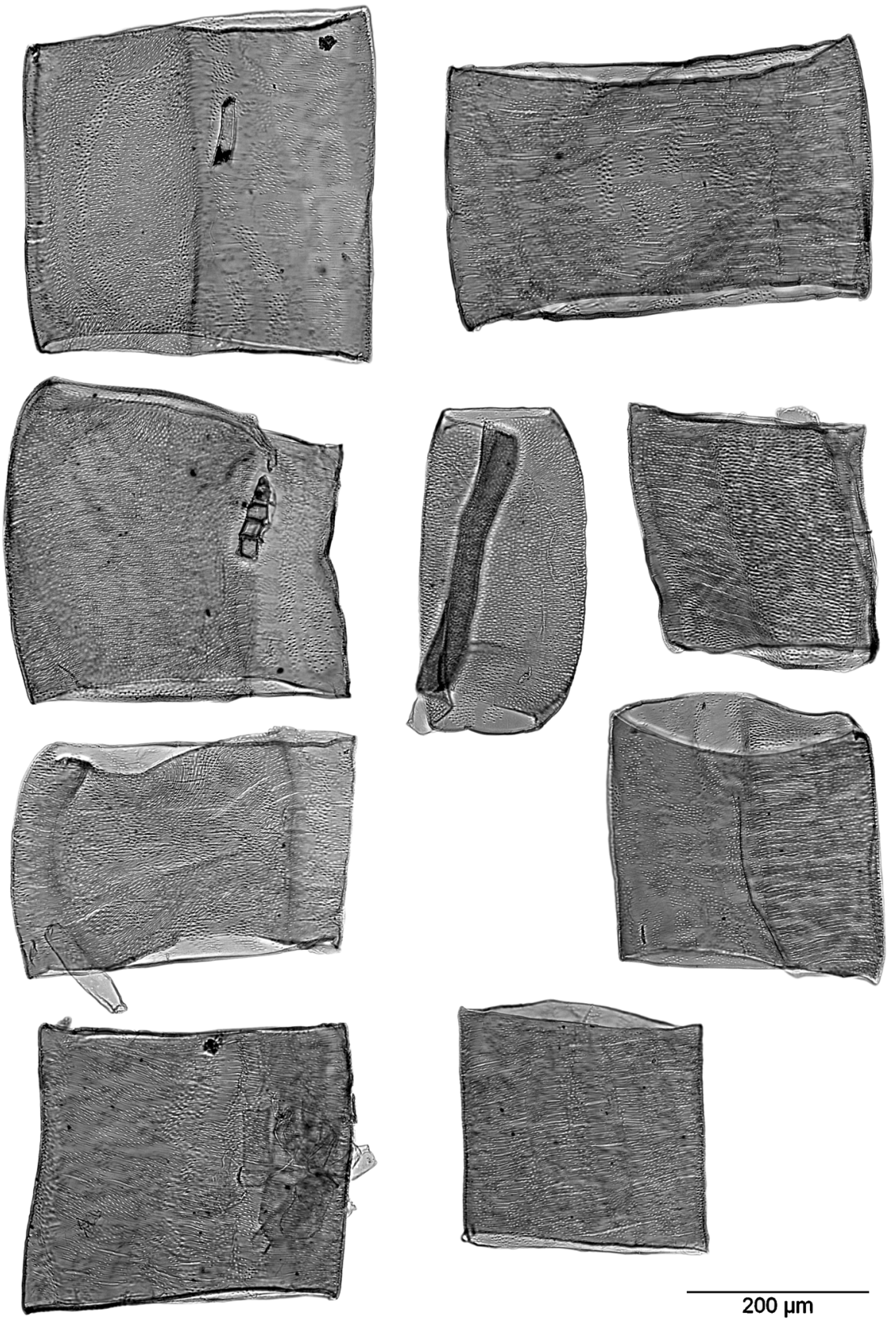

Heritiera sp. 


\section{Heritiera sp. (Malvaceae)}

Trade names: mengkulang (MY); palapi, teraling, tarrietia (ID); huynh (VN); dong chem, sempong, sonloc (KH); lumbayau (PH); may nhom pa (LA), kanzo (MM).

DIN EN 13556:2003 code: HEXM.

CITES regulations: not protected.

Geographic distribution: Tropical Africa, Southern Asia from India to New Guinea, Micronesia and tropical Australia.

Vessel elements: rather short and wide (length about $250 \mu \mathrm{m}$, width about $350 \mu \mathrm{m}$ ); mainly drum-shaped, sometimes barrel-shaped.

Tails: rarely present; long with gradual transition; pitted.

Perforation plates: simple, extending over the entire lumen; horizontal.

Intervessel pits: alternate; vertical diameter 3-5-9 $\mu \mathrm{m}$; present in large fields over a wide area.

Vessel-ray pits and pits to parenchyma cells: APS; cross-fields aligned in horizontal (vessel-ray pits) or vertical (pits to parenchyma cells) series, similar to those of Tetramerista sp.; apertures slit-like, in centre of the cross-fields sometimes coalescent.

Areas without any pits: if present, very small.

Tyloses and helical thickenings: absent.

Notes on identification: see Tetramerista glabra (p. 292).

\section{Quantitative data:}

Vessel elements (175-)250(-369) $\mu \mathrm{m}$ long, and (126-)345(-471) $\mu \mathrm{m}$ wide; $1 / \mathrm{w}$ ratio 0.8 .

Intervessel pit borders (2.7-)4.9(-9.4) $\mu \mathrm{m}$ in vertical diameter; pit apertures (0.7-) $1.2(-3.0) \mu \mathrm{m}$.

Fibers $1290 \mu \mathrm{m}$ long, $21.0 \mu \mathrm{m}$ wide. Fiber wall thickness $5.1 \mu \mathrm{m}$ (weighted averages). 

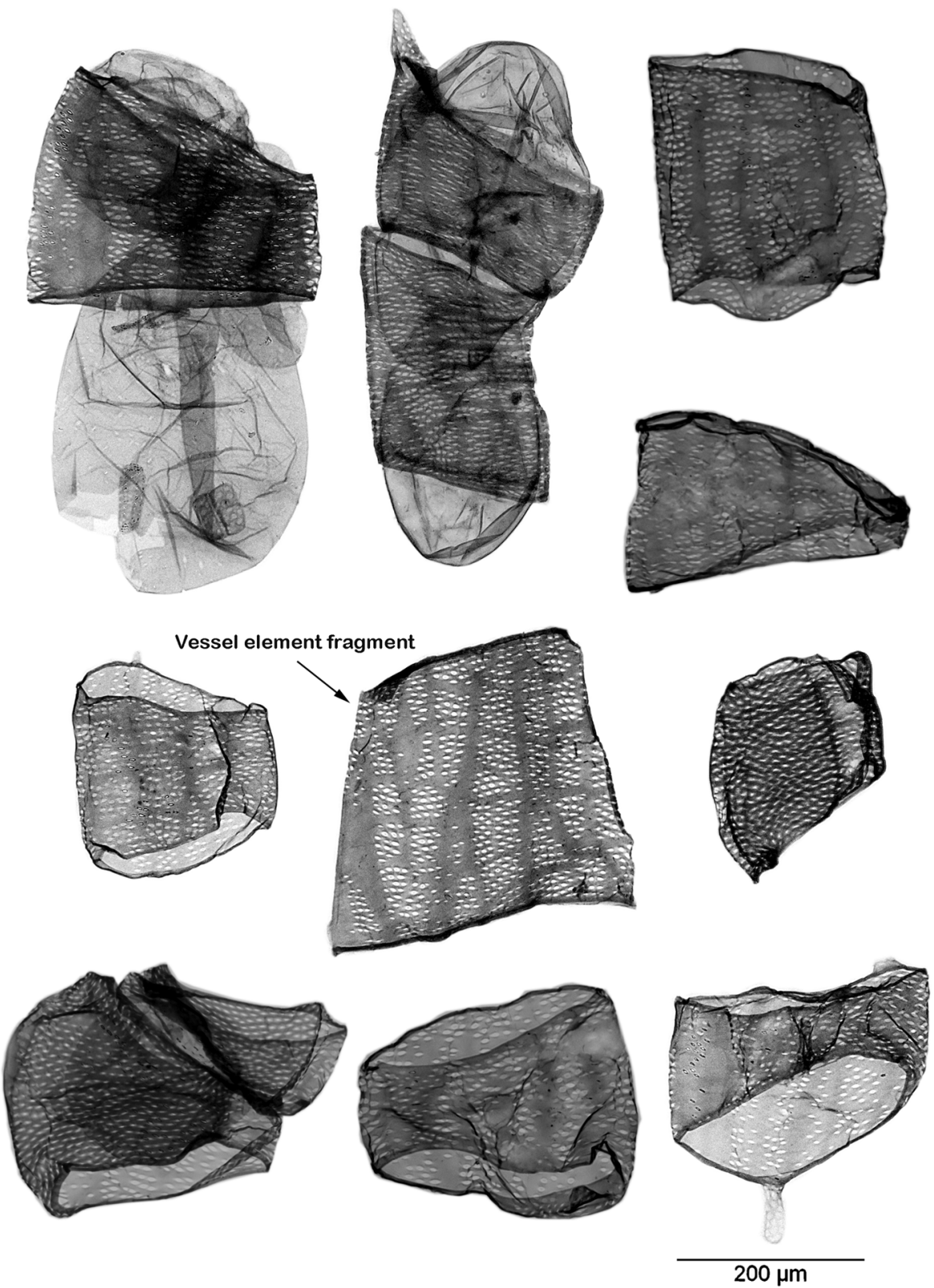

Paulownia tomentosa 


\section{Paulownia tomentosa (Thunb.) Steud. (Paulowniaceae)}

Trade names: kiri, shima-giri (JP); mao pao tong (CN); paulownia impérial (FR); empresstree (GB, US); Chinesischer Blauglockenbaum (DE).

DIN EN 13556:2003 code: not listed.

CITES regulations: not protected.

Geographic distribution: Temperate Asia. Cultivated worldwide in regions with a temperate or subtropical climate.

Vessel elements: rather short and wide (length about $180 \mu \mathrm{m}$, width about $250 \mu \mathrm{m}$ ); mainly drum-shaped (those with a larger diameter, earlywood vessel elements), sometimes barrel-shaped (those with a smaller diameter, latewood vessel elements).

Arrow: One vessel element was cut in half to improve the presentation of the characteristics (pit arrangement).

Tails: rare, short with abrupt transition.

Perforation plates: simple, extending over the entire lumen; horizontal or inclined.

Intervessel pits: alternate; vertical diameter 3-6-9 $\mu \mathrm{m}$; distributed over a wide area on the entire vessel element wall; apertures oval.

Vessel-ray pits: APS; cross-fields in horizontal series of mostly two rows of pits; pits occasionally with large apertures resembling simple pits.

Pits to axial parenchyma cells: numerous, sometimes larger than the intervessel pits; cross-fields in neatly vertical series.

Areas without any pits: regularly present; small.

Tyloses: present.

Helical thickenings: absent.

\section{Quantitative data:}

Vessel elements (60-) 175(-325) $\mu \mathrm{m}$ long, and (50-)245(-361) $\mu \mathrm{m}$ wide; $1 / \mathrm{w}$ ratio 0.7 .

Intervessel pit borders (2.7-)5.7(-9.2) $\mu \mathrm{m}$ in vertical diameter; pit apertures (0.9-) $1.5(-3.8) \mu \mathrm{m}$.

Fibers $560 \mu \mathrm{m}$ long, $25.8 \mu \mathrm{m}$ wide. Fiber wall thickness $3.0 \mu \mathrm{m}$ (weighted averages). 


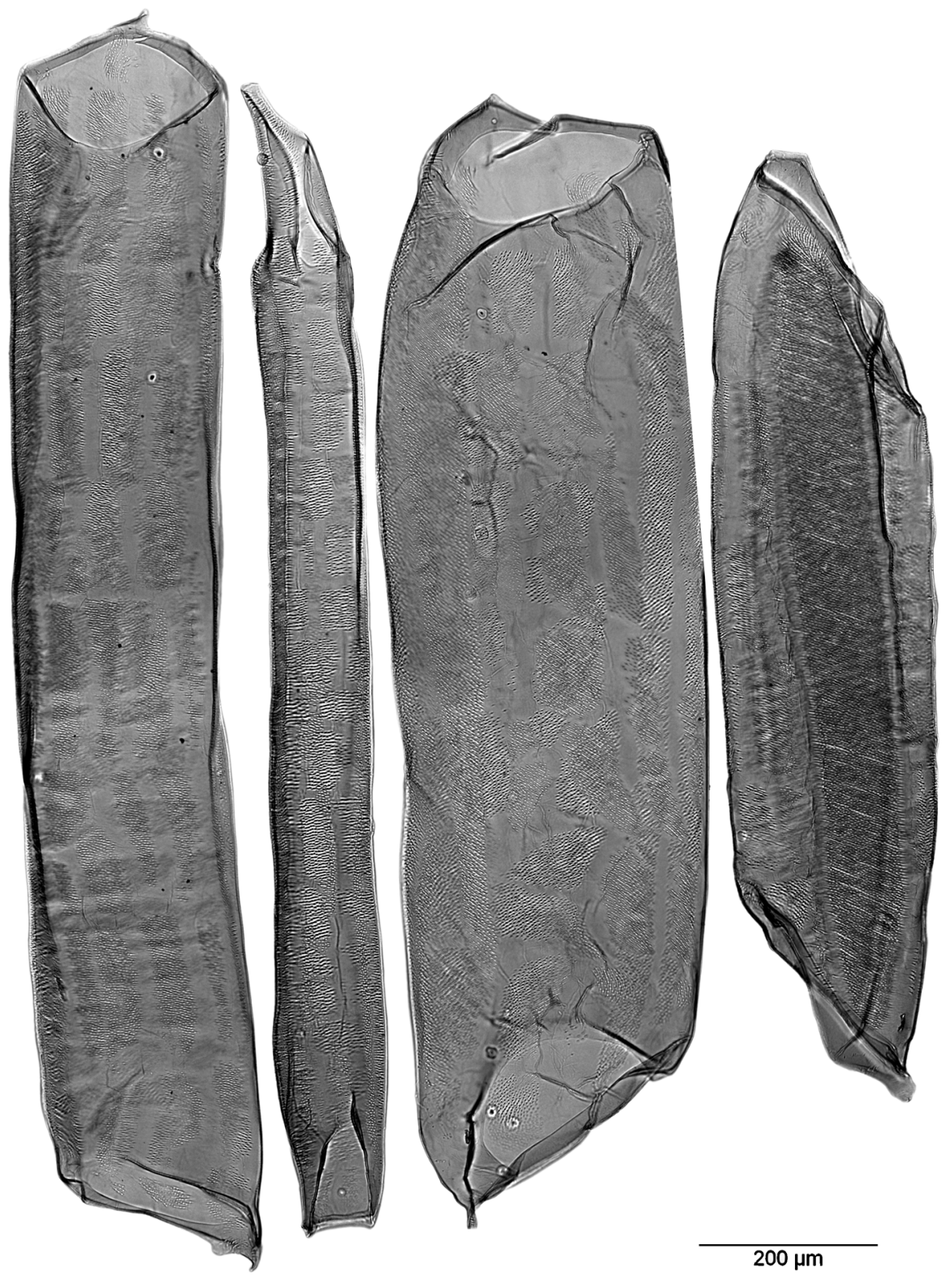

Tetramerista glabra 


\section{Tetramerista glabra Miq. (Tetrameristaceae)}

Trade names: punah (MY); entuyut (MY-swk); tuyut (MY-sab); punak (ID).

DIN EN 13556:2003 code: not listed.

CITES regulations: not protected.

Geographic distribution: Western Indomalesia.

Vessel elements: very long (about $980 \mu \mathrm{m}$ ), width varies from slim to quite wide (average about $290 \mu \mathrm{m})$; mainly tube-shaped.

Tails: short with abrupt transition or longer with gradual transition.

Perforation plates: simple, often extending over the entire lumen; inclined.

Intervessel pits: alternate; very small; vertical diameter $2-3-5 \mu \mathrm{m}$; covering large vessel wall areas; apertures circular to oval; inner pit apertures slit-like and coalescent: forming diagonal striations (similar to Heritiera sp., p. 288).

Vessel-ray pits: APS; in horizontal series of small cross-fields, pits with oval apertures.

Pits to axial parenchyma cells: in vertical series of elongated cross-fields separated by pit-free lines; inner pit apertures slit-like, partly coalescent, connecting 2-4 pits.

Areas without any pits: regularly present; rather small to sometimes large.

Tyloses and helical thickenings: absent.

Notes on identification: The pit shape of Tetramerista spp. is similar to that of Heritiera spp. (p. 288), but the vessel elements are longer.

\section{Quantitative data:}

Vessel elements (479-)978(-1390) $\mu \mathrm{m}$ long, and (108-)288(-387) $\mu \mathrm{m}$ wide; $1 / \mathrm{w}$ ratio 3.5 .

Intervessel pit borders (2.1-) 3.3(-5.2) $\mu \mathrm{m}$ in vertical diameter; pit apertures (0.4-) $0.8(-1.4) \mu \mathrm{m}$.

Fibers $895 \mu \mathrm{m}$ long, $30.2 \mu \mathrm{m}$ wide. Fiber wall thickness $7.0 \mu \mathrm{m}$ (weighted averages). 
IAWA Journal 39 (3), 2018

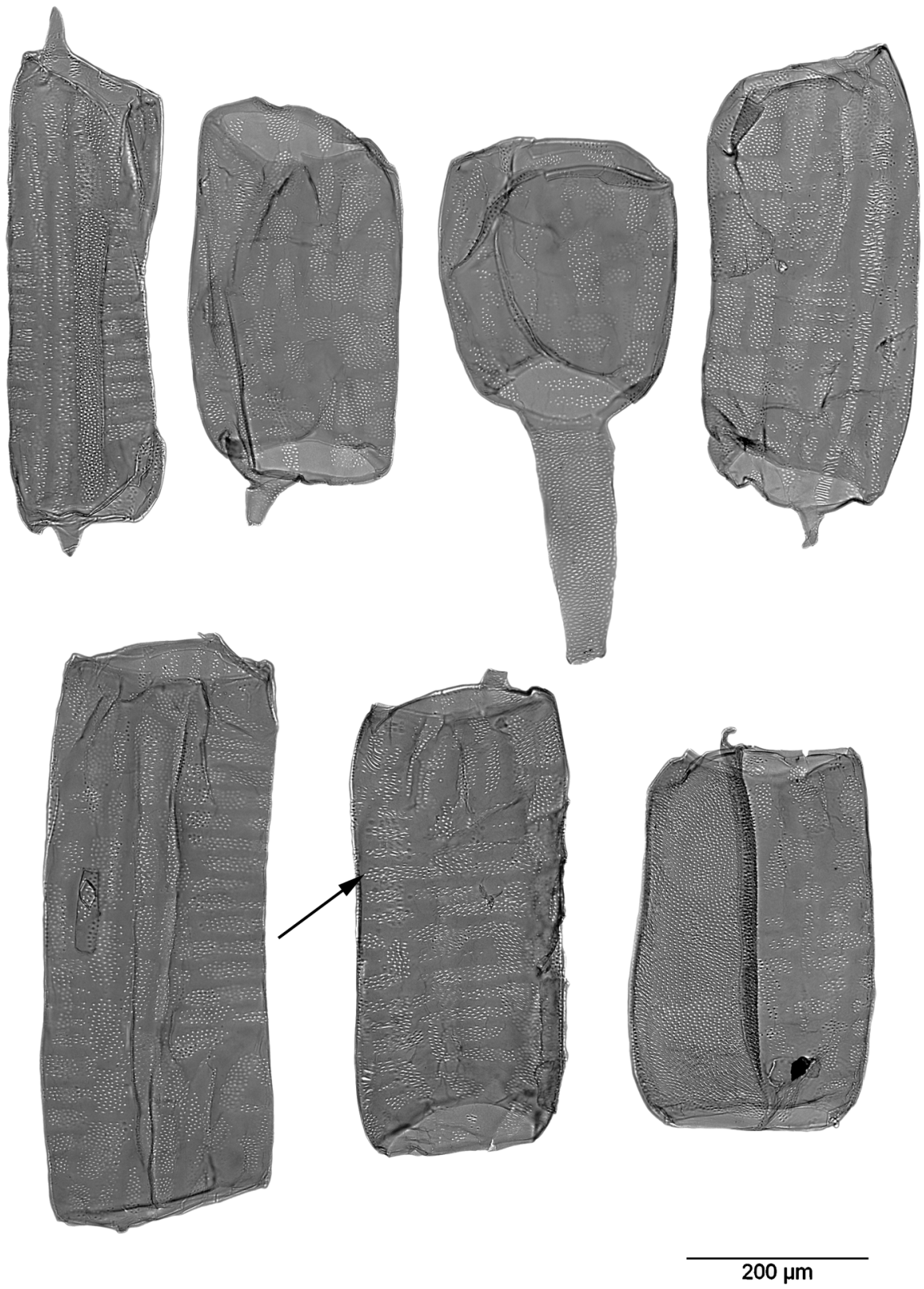

Gonystylus sp. 


\section{Gonystylus sp. (Thymelaeaceae)}

Trade name: ramin (DE, GB, MY, ID).

DIN EN 13556:2003 code: GYBN (G. bancanus (Miq.) Kurz).

CITES regulations: protected (Annex II).

Geographic distribution: Indomalesia and West Pacific islands (Fiji).

The wood was often used for furniture, broomsticks and moldings.

Vessel elements: of medium size or large (length $410 \mu \mathrm{m}$, width $210 \mu \mathrm{m}$ ); often elongated (barrel-shaped), rarely drum-shaped.

Tails: often short and rarely long; both with abrupt transition.

Perforation plates: simple, mostly extending over the entire lumen; horizontal or slightly inclined and narrowed.

Intervessel pits: alternate; vertical diameter 3-5 $\mu \mathrm{m}$; present over a wide area and in the tails.

Vessel-ray pits: APS; cross-fields in horizontal series (3-6 pit rows per ray cell); apertures oval, sometimes slit-like.

Pits to axial parenchyma cells: cross-fields arranged in vertical series, separated by pitless strips.

Areas without any pits: regularly present; rather small, sometimes larger.

Tyloses and helical thickenings: absent.

Notes on identification: Vessel elements of Gonystylus spp. are similar in their appearance to those of Durio spp. and Lophopetalum spp. Corners of cross-fields of vessel-ray pits often rounded (arrow) as pits in the corners are often missing (Lophopetalum spp.: cross-fields rectangular, “corner pits" present, p. 276).

\section{Quantitative data:}

Vessel elements (292-)412(-607) $\mu \mathrm{m}$ long, and (92-)214(-262) $\mu \mathrm{m}$ wide; $1 / \mathrm{w}$ ratio 2.0 .

Intervessel pit borders (2.6-)3.4(-5.3) $\mu \mathrm{m}$ in vertical diameter; pit apertures (0.5-) $1.0(-2.0) \mu \mathrm{m}$.

Fibers $1160 \mu \mathrm{m}$ long, $29.0 \mu \mathrm{m}$ wide. Fiber wall thickness $7.4 \mu \mathrm{m}$ (weighted averages). 


\section{"VAS" (Vessel-ray pits Apparently Simple) introductory comments}

In the 19 genera and subgenera belonging to this group the vessel-ray pits differ in type and shape from the intervessel pits. The borders of the vessel-ray pits are not or hardly visible under the light microscope - and pits are called "apparently simple", represented by the acronym "VAS" (Vessel-ray pits Apparently Simple). Due to the different shapes of the pit apertures they can be subdivided into three groups. Figure 13 shows three different types of pit shapes and arrangement.

The numerous vessel-ray pits and pits to axial parenchyma cells of Anacardiaceae have a remarkable appearance. The apertures are elongated and resemble eyes (Fig. 13 A).

Reticulate vessel-ray pits are common in the species of Canarium, Calophyllum, Hevea brasiliensis, Castanopsis argentea, Eucalyptus globulus, Madhuca sericea, and Syzygium dyerianum. The vessel-ray pits are arranged in horizontal rows along the rays and resemble a net-like structure (Fig. 13B).

Furthermore, this group also includes the important subgenera of Shorea and two further genera of the Dipterocarpaceae. The vessel elements are mainly barrel-shaped.

Based on practical experience, it is possible to identify the vessel elements of the genus Shorea but it is impossible to separate the individual subgenera. Considering the family as a whole, there is a high risk to confuse the economically important genera, e.g. Shorea, Parashorea, and Dipterocarpus. However, the appearance of the simple vessel-ray pits and the pits to axial parenchyma cells of Shorea differ remarkably in size and shape (Fig. 13C).

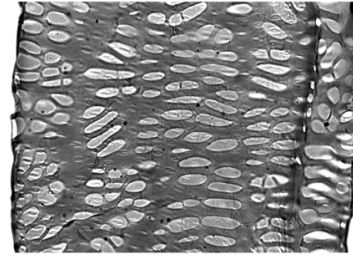

A

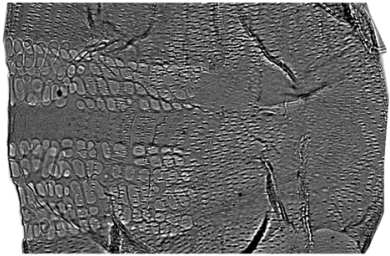

B

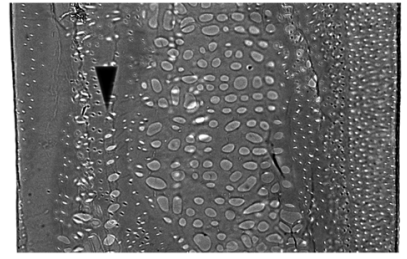

C
$200 \mu \mathrm{m}$

Figure 13. - A: gash-like vessel-ray pit apertures, Swintonia sp. - B: reticulate (and partly palisade) vessel-ray pits, Calophyllum sp. - C: diversity of pit sizes and shapes: vessel-ray pits and pits to axial parenchyma cells (arrowhead), Shorea subg. Rubroshorea. 
Figure 14 shows the variation of vessel element length and width as well as the vertical diameter of the apertures and borders of intervessel pits. The boxplots of the length (Fig. 14a), width (Fig. 14b) and the borders of the intervessel pits (Fig. 14d) show how variable the dimensions of the different species can be. The dimensions of the apertures of the intervessel pits (Fig. 14c) lie close together, with some deviations (e.g. Calophyllum sp., Madhuca sericea, and Canarium sp.).

Mangifera sp. possesses the shortest vessel elements in this group (Fig. 14a) whereas the width of Mangifera sp. is average (Fig. 14b). Syzygium dyerianum reveals the longest vessel elements (Fig. 14a) whereas the width is similar to that of Mangifera sp. (Fig. 14b).

Because we only studied one sample per genus or species, these differences must be tested with much broader sampling.
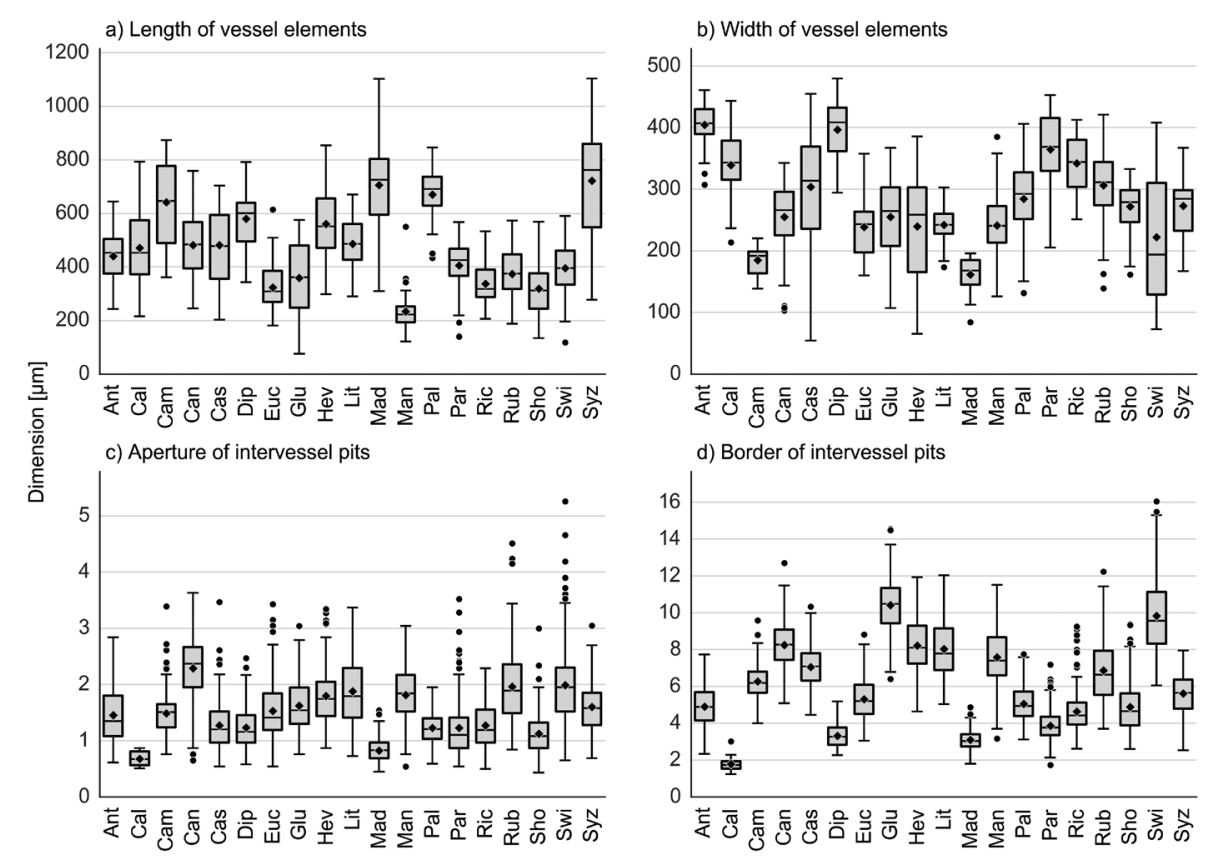

Figure 14. Boxplots of 19 wood genera/species (length and width of the vessel elements, diameter of pit apertures and borders).

Ant $=$ Shorea subg. Anthoshorea $; \mathrm{Cal}=$ Calophyllum sp $;$ Cam $=$ Campnosperma $\mathrm{sp} . ; \mathrm{Can}=$ Canarium sp.; Cas = Castanopsis argentea $;$ Dip = Dipterocarpus sp.; Euc = Eucalyptus sp.; $\mathrm{Glu}=$ Gluta renghas $; \mathrm{Hev}=$ Hevea brasiliensis $;$ Lit = Litsea resinosa $;$ Mad = Madhuca seri cea ; Man = Mangifera sp.; Pal = Palaquium sp.; Par = Parashorea sp.; Ric = Shorea subg. Richetia $;$ Rub $=$ Shorea subg. Rubroshorea $;$ Sho $=$ Shorea subg. Shorea $;$ Swi $=$ Swintonia $\mathrm{sp} . ;$ Syz $=$ Syzygium dyerianum . 


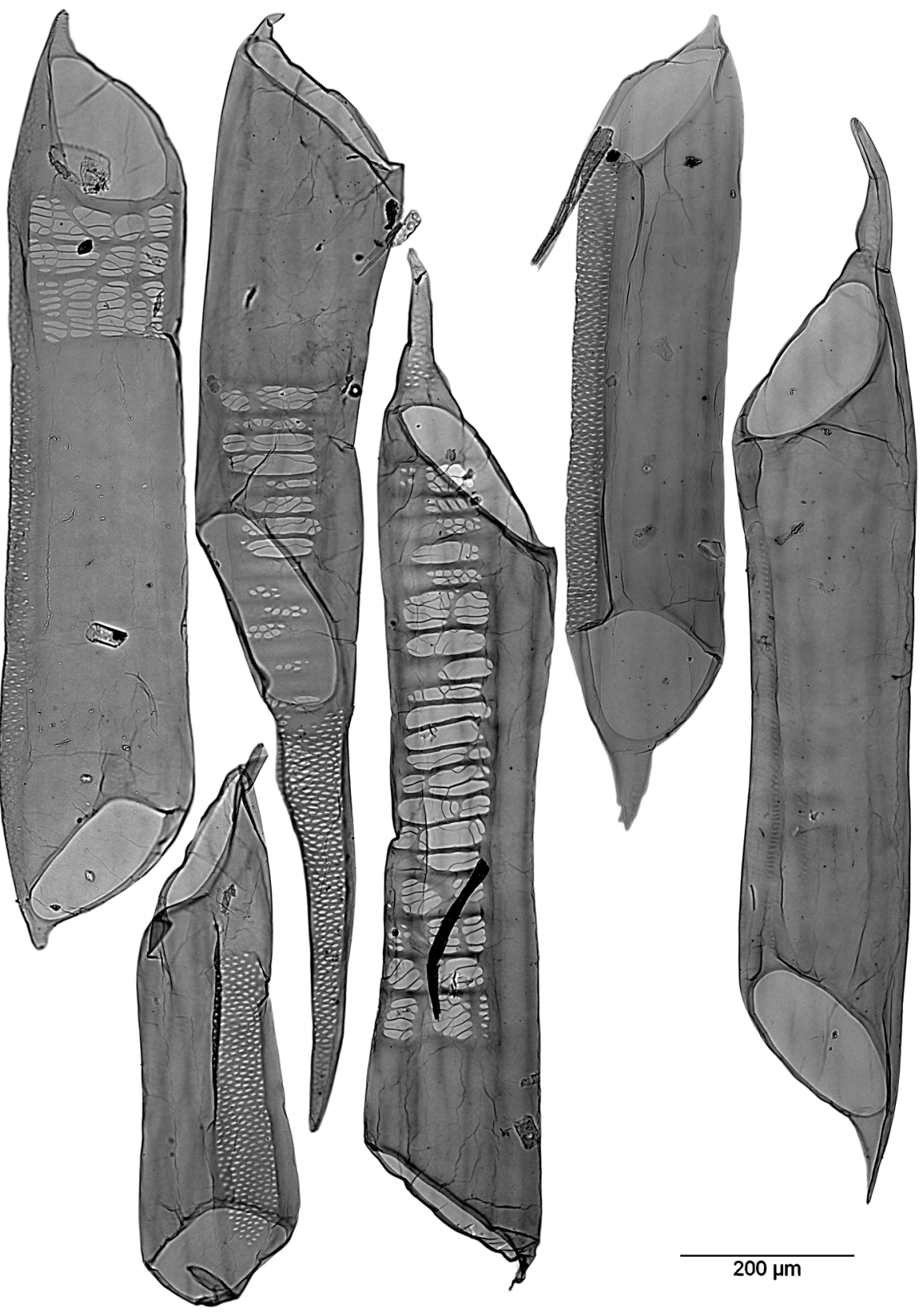

Campnosperma sp. 


\section{Campnosperma sp. (Anacardiaceae)}

Trade names: terentang, kelinting, melumut, serentang (MY); pauh lebi, tumbus (ID); campnosperma (PG); nangpron, huasum sangtrang (TH); nisperillo, orey, sajo (PA).

DIN EN 13556:2003 code: not listed.

CITES regulations: not protected.

Geographic distribution: South and Central America, Madagascar, Seychelles, Sri Lanka, the whole Southeast Asia, Micronesia and Melanesia.

Vessel elements: long and slim (tube-shaped), length about $650 \mu \mathrm{m}$, width about $190 \mu \mathrm{m}$.

Tails: either short or long with gradual transition; larger tails often covered with pits.

Perforation plates: simple and more rarely scalariform (with 6-36 bars; Richter \& Dallwitz 2000); extending over the entire lumen; inclined (parallelogram or trapezium).

Intervessel pits: alternate; vertical diameter 4-6-10 $\mu \mathrm{m}$; present over a wide area; apertures oval to slit-like.

Vessel-ray pits: VAS; large; apertures window-like, sometimes subdivided into smaller units but still large; shape varies from elongated to oval or circular.

Pits to fibers: rarely present, arranged in short single vertical rows.

Areas without any pits: regularly present; very large.

Tyloses: present.

Helical thickenings: absent.

\section{Quantitative data:}

Vessel elements (361-)646(-873) $\mu \mathrm{m}$ long, and (139-) 192(-220) $\mu \mathrm{m}$ wide; $1 / \mathrm{w}$ ratio 3.7.

Intervessel pit borders (4.0-)6.2(-9.6) $\mu \mathrm{m}$ in vertical diameter; pit apertures $(0.8-)$ $1.5(-3.4) \mu \mathrm{m}$.

Fibers $950 \mu \mathrm{m}$ long, $24.5 \mu \mathrm{m}$ wide. Fiber wall thickness $7.7 \mu \mathrm{m}$ (weighted averages). 

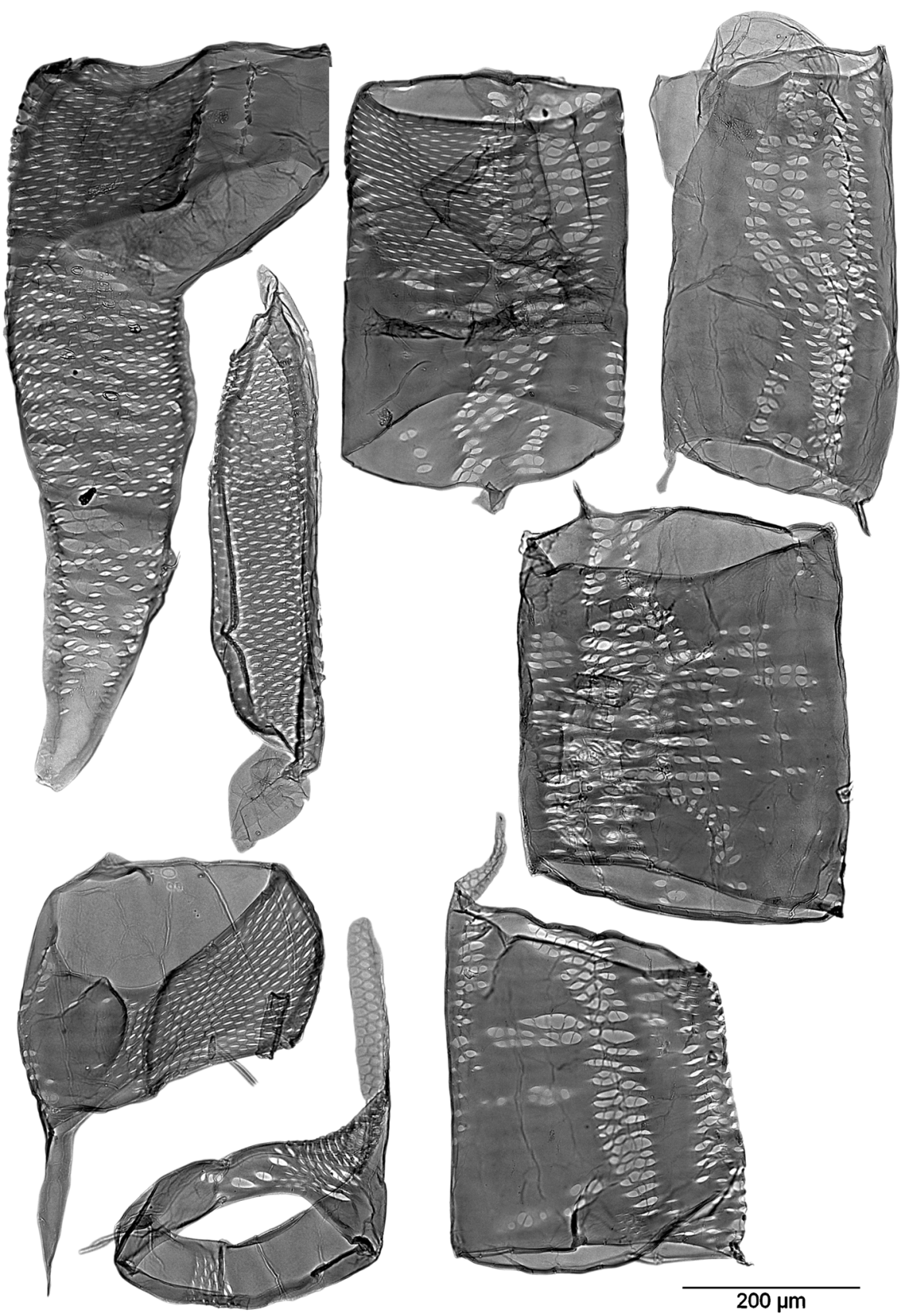

Gluta renghas 


\section{Gluta renghas L. (Anacardiaceae)}

Trade names: rengas, rengas kerbau jalang (MY); rengas tembaga(ID); hekakoro (PG); thayet-thitsi (MM); kroeul (KH); rakban (TH).

DIN EN 13556:2003 code: not listed.

CITES regulations: not protected.

Geographic distribution: Indochina to Indomalesia (one species in Madagascar).

Vessel elements: rather large, some very short (length about $360 \mu \mathrm{m}$, width about $270 \mu \mathrm{m})$; barrel or drum-shaped.

Tails: either short with abrupt transition or very long with gradual transition.

Perforation plates: simple, extending over the entire lumen; horizontal or slightly inclined.

Intervessel pits: alternate; vertical diameter 6-11-15 $\mu \mathrm{m}$; present over a wide area; apertures oval.

Vessel-ray pits: VAS; arranged in horizontal rows; similar to pits to axial parenchyma cells.

Pits to axial parenchyma cells: similar to vessel-ray pits in size and shape; arranged in vertical series.

Areas without any pits: regularly present; large to very large.

Tyloses: present.

Helical thickenings: absent.

Notes on identification: The vessel elements of Gluta renghas are similar to those of Mangifera spp. and Swintonia spp. (see Mangifera sp., p. 302).

\section{Quantitative data:}

Vessel elements (76-)361 (-576) $\mu \mathrm{m}$ long, and (107-) 265(-367) $\mu \mathrm{m}$ wide; $1 / \mathrm{w}$ ratio 1.4 .

Intervessel pit borders (6.4-) $10.5(-14.6) \mu \mathrm{m}$ in vertical diameter; pit apertures $(0.8-)$ $1.5(-3.0) \mu \mathrm{m}$.

Fibers $945 \mu \mathrm{m}$ long, $20.9 \mu \mathrm{m}$ wide. Fiber wall thickness $6.0 \mu \mathrm{m}$ (weighted averages). 
IAWA Journal 39 (3), 2018
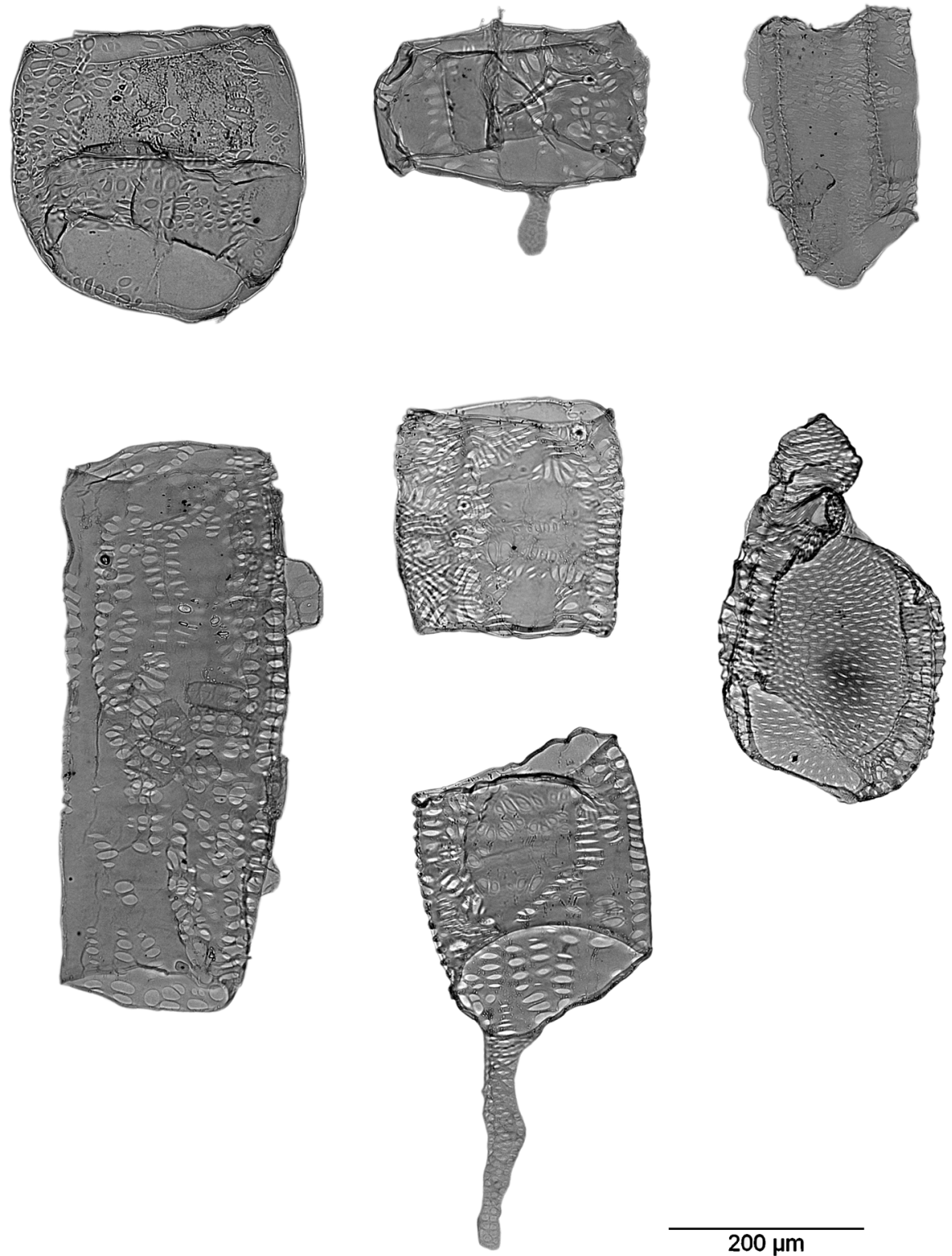

Mangifera sp. 


\section{Mangifera sp. (Anacardiaceae)}

Trade names: machang, tiger wood (MY), mango (IN).

DIN EN 13556:2003 code: not listed.

CITES regulations: not protected.

Geographic distribution: India, Pakistan, Sri Lanka, Indochina, Indomalesia.

Mangifera sp. is cultivated as a fruit tree. The wood is commonly used for furniture and plywood cores.

Vessel elements: rather short (length about $220 \mu \mathrm{m}$, width about $250 \mu \mathrm{m}$ ), often drumshaped, sometimes elongated (tube-shaped).

Tails: often long with abrupt transition or short with gradual transition.

Perforation plates: simple, extending over the entire lumen; horizontal or slightly inclined.

Intervessel pits: pits alternate; vertical diameter 3-7-12 $\mu \mathrm{m}$; present over a wide area and in the tails; apertures oval.

Vessel-ray pits: VAS; isodiametric or stretched (eye-shaped); in one ray cell all the pits are of the same type; present on nearly every vessel element.

Areas without any pits: regularly present; small to large.

Tyloses: present, thin-walled.

Helical thickenings: absent.

Notes on identification: The vessel elements of Mangifera spp. are similar to those of Gluta renghas spp. and Swintonia spp. Mangifera sp. has the smallest vessel elements with small intervessel pits. Swintonia sp. is characterized by the largest intervessel pits. The three genera show very similar pit features.

\section{Quantitative data:}

Vessel elements (75-) $221(-550) \mu \mathrm{m}$ long, and (126-) $241(-385) \mu \mathrm{m}$ wide; $1 / \mathrm{w}$ ratio 0.9 .

Intervessel pit borders (3.2-) 7.4(-11.5) $\mu \mathrm{m}$ in vertical diameter; pit apertures (0.5-) $1.8(-3.0) \mu \mathrm{m}$.

Fibers $700 \mu \mathrm{m}$ long, $20.8 \mu \mathrm{m}$ wide. Fiber wall thickness $5.8 \mu \mathrm{m}$ (weighted averages). 

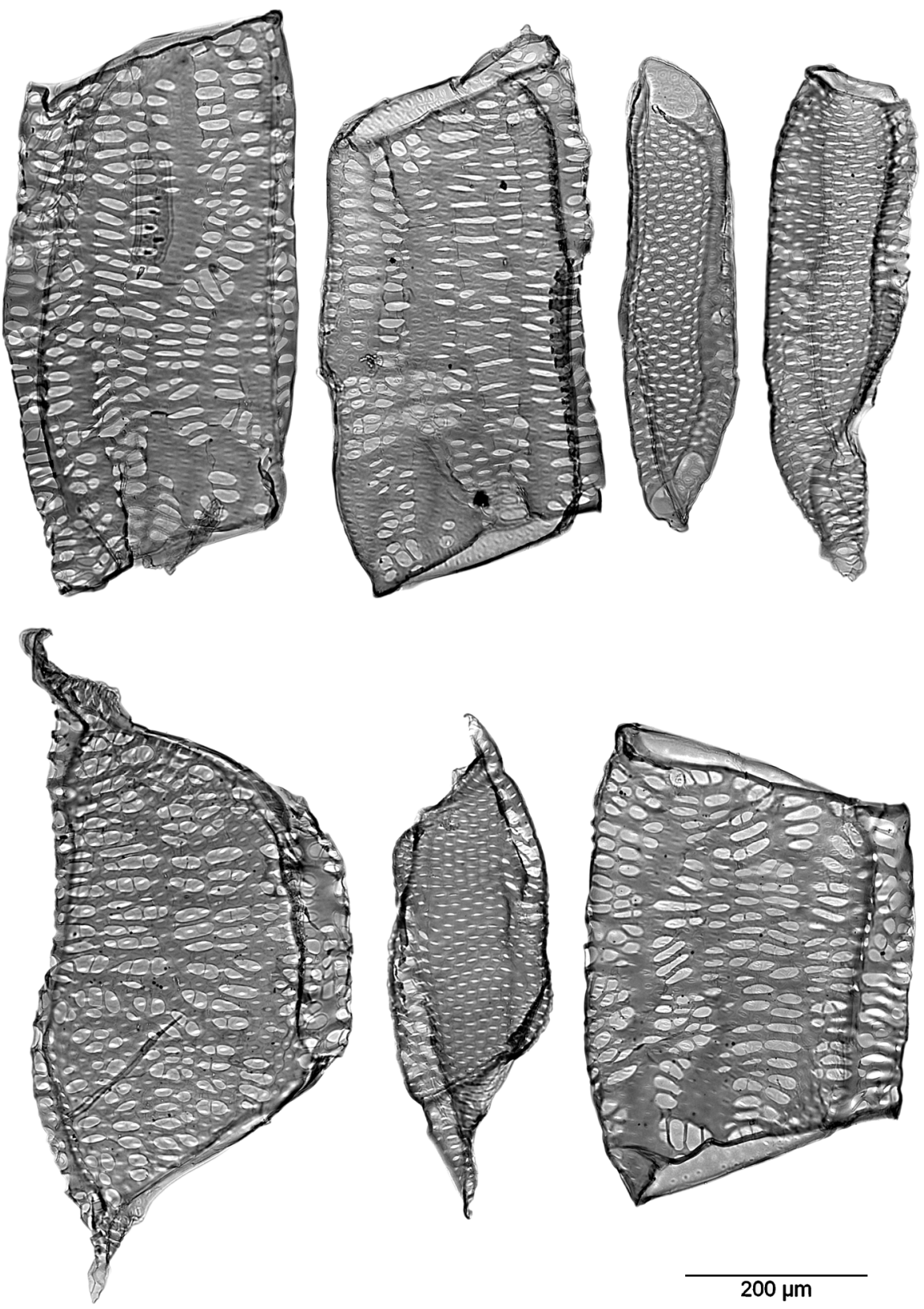

Swintonia sp. 


\section{Swintonia sp. (Anacardiaceae)}

Trade names: merpauh, selan (MY-swk); kaluis, lomarau (PH); civit, taung-thayet (MM); muom (KH, VN).

DIN EN 13556:2003 code: not listed.

CITES regulations: not protected.

Geographic distribution: Bangladesh, Indochina to Indomalesia.

Vessel elements: of average size (length about $400 \mu \mathrm{m}$, width about $190 \mu \mathrm{m}$ ); mainly barrel-shaped (those with a larger diameter), sometimes tube-shaped (those with a smaller diameter); width varies from average to slim dimensions.

Tails: if present often short with gradual transition.

Perforation plates: simple, extending over the entire lumen; inclined (trapezium or parallelogram).

Intervessel pits: alternate; quite large; vertical diameter 6-10-16 $\mu \mathrm{m}$; present over a wide area and in the tails; apertures oval.

Vessel-ray pits: VAS; very large, window-like arranged in 2-3 rows per cross-field.

Pits to axial parenchyma cells: elongate, often present over the entire vessel element wall.

Areas without any pits: if present, very small.

Tyloses: present.

Helical thickenings: absent.

Notes on identification: The vessel elements of Swintonia spp. are similar to those of Gluta renghas spp. and Mangifera spp. (see Mangifera sp., p. 302).

\section{Quantitative data:}

Vessel elements (119-)396(-590) $\mu \mathrm{m}$ long, and (73-) 194(-408) $\mu \mathrm{m}$ wide; 1/w ratio 1.8 .

Intervessel pit borders (6.1-)9.6(-16.1) $\mu \mathrm{m}$ in vertical diameter; pit apertures (0.7-) $2.0(-5.3) \mu \mathrm{m}$.

Fibers $930 \mu \mathrm{m}$ long, $23.5 \mu \mathrm{m}$ wide. Fiber wall thickness $8.7 \mu \mathrm{m}$ (weighted averages). 

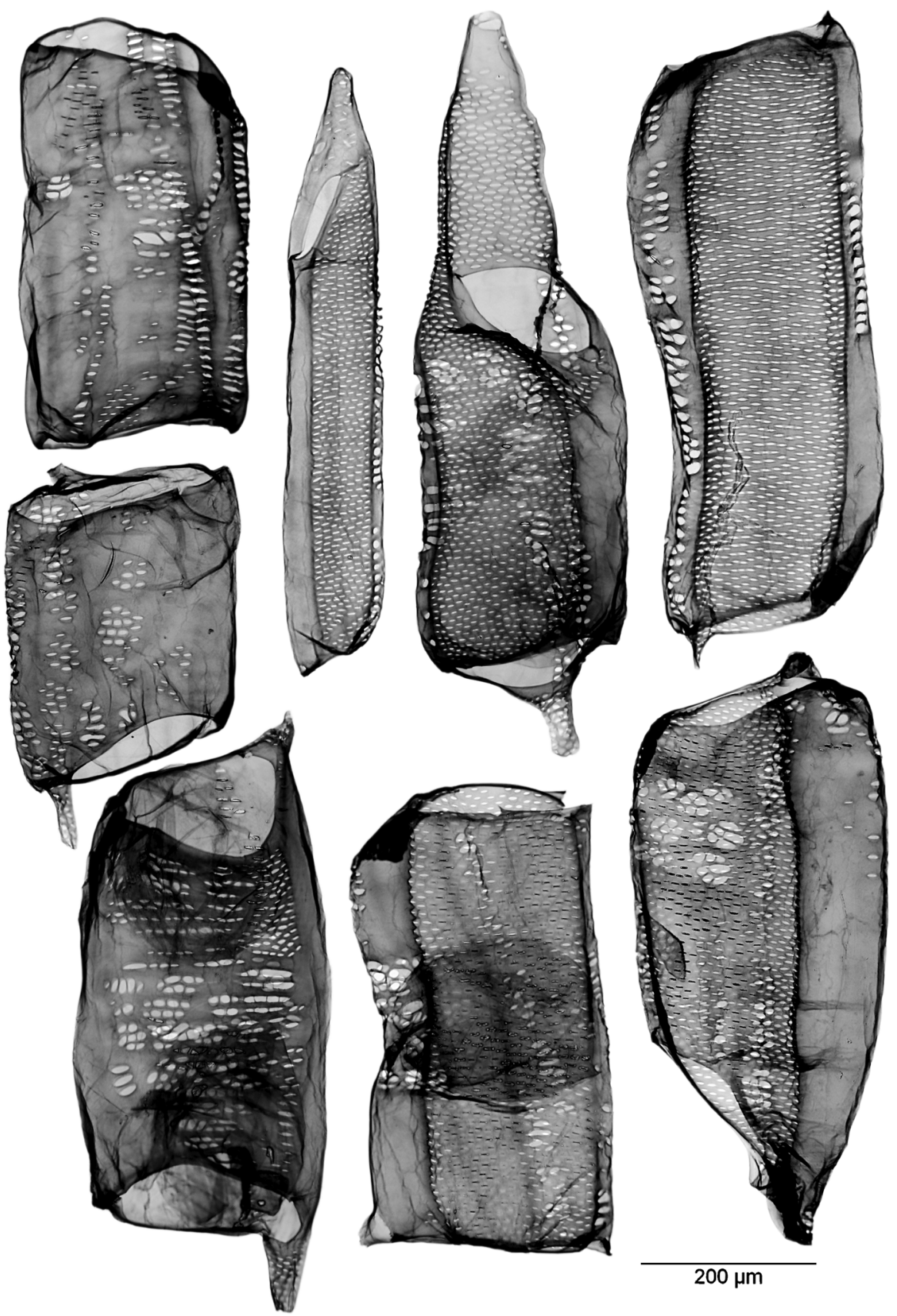

Canarium sp. 


\section{Canarium sp. (Burseraceae)}

Trade names: kedondong, kenari, kerantai (ID); kerantai, upi, seladah (MY); upi (BN, MY-swk); canarium, galip (PG); pili, pilingliitan, pagsahingin (PH); makoem (TH); tram $(\mathrm{VN})$.

DIN EN 13556:2003 code: CNXX.

CITES regulations: not protected.

Geographic distribution: "Old world tropics" from tropical Africa to tropical Asia, northern Australia and the Pacific.

Vessel elements: rather large (length about $480 \mu \mathrm{m}$, width about $270 \mu \mathrm{m}$ ); mainly barrel-shaped (those with a larger diameter), sometimes tube-shaped (those with a smaller diameter).

Tails: if present, rather short with abrupt transition or very long with gradual transition.

Perforation plates: simple, often extending over the entire lumen; horizontal or inclined.

Intervessel pits: alternate; vertical diameter 5-8-13 $\mu \mathrm{m}$; often present over a wide area covering the entire vessel element wall.

Vessel-ray pits: VAS; cross-fields arranged in horizontal series, with one or several rows of pits variable in size.

Pits to fibers: rarely present, arranged in single vertical rows.

Areas without any pits: present on radial faces; large to very large.

Tyloses: present.

Helical thickenings: absent.

Quantitative data:

Vessel elements (246-)484(-759) $\mu \mathrm{m}$ long, and (103-) 266(-343) $\mu \mathrm{m}$ wide; $1 / \mathrm{w}$ ratio 1.9 .

Intervessel pit borders (5.1-) 8.3(-12.7) $\mu \mathrm{m}$ in vertical diameter; pit apertures (0.7-) $2.4(-3.6) \mu \mathrm{m}$.

Fibers $920 \mu \mathrm{m}$ long, $24.7 \mu \mathrm{m}$ wide. Fiber wall thickness $4.2 \mu \mathrm{m}$ (weighted averages). 


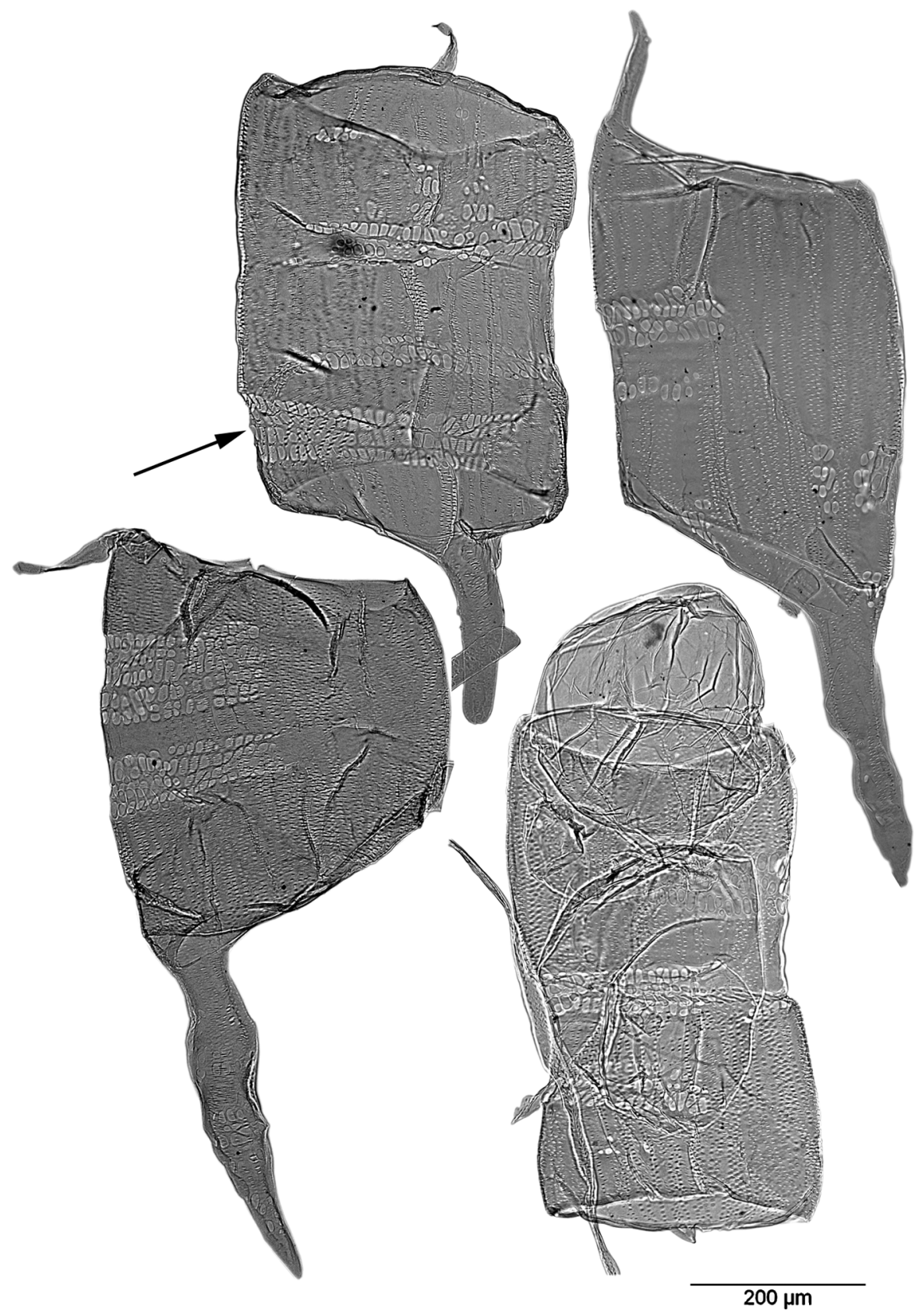

Calophyllum sp. 


\section{Calophyllum sp. (Calophyllaceae)}

Trade names: bintangor (MY, DE); bitaog, kalofilum, kamdeb, tamanu, bakokol, entangor, mentangor (MY); ponnyet, tharapi (MM); domba-gassa (LK); bansangal, vutalau, zarumayen $(\mathrm{PH})$; vintanina $(\mathrm{MG})$; palo maría $(\mathrm{PH}=C$. inophyllum $)$, Alexandrien laurel $(\mathrm{IN}=C$. inophyllum $)$.

DIN EN 13556:2003 code: CLXX.

CITES regulations: not protected.

Geographic distribution: Indomalesia, Micronesia, Melanesia and northern Australia, also in Central and South America, Madagascar and surrounding islands.

Vessel elements: rather large (length about $450 \mu \mathrm{m}$, width about $340 \mu \mathrm{m}$ ); elongated (barrel-shaped) or shorter (drum-shaped).

Tails: long with abrupt transition, sometimes shorter.

Perforation plates: simple, extending over the entire lumen; horizontal or slightly inclined.

Intervessel pits: absent (due to vessels being almost exclusively solitary in the intact wood).

Vessel-ray pits: VAS; window-like (angled to oval), cross-fields with 2-5 horizontal rows of pits arranged in a reticulate pattern (arrow).

Pits to tracheids: numerous; in 2-3-seriate bands; vertical diameter 1-2-3 $\mu \mathrm{m}$; apertures oval to slit-like; pits alternate.

Areas without any pits: if present, small.

Tyloses: present.

Helical thickenings: absent.

\section{Quantitative data:}

Vessel elements (216-) $453(-794) \mu \mathrm{m}$ long, and (214-)343(-443) $\mu \mathrm{m}$ wide; $1 / \mathrm{w}$ ratio 1.3 .

Vessel to tracheid pit borders (1.2-) 1.7(-3.0) $\mu \mathrm{m}$ in vertical diameter; pit apertures (0.5-)0.7(-0.9) $\mu \mathrm{m}$.

Fibers $1120 \mu \mathrm{m}$ long, $24.4 \mu \mathrm{m}$ wide. Fiber wall thickness $7.2 \mu \mathrm{m}$ (weighted averages). 

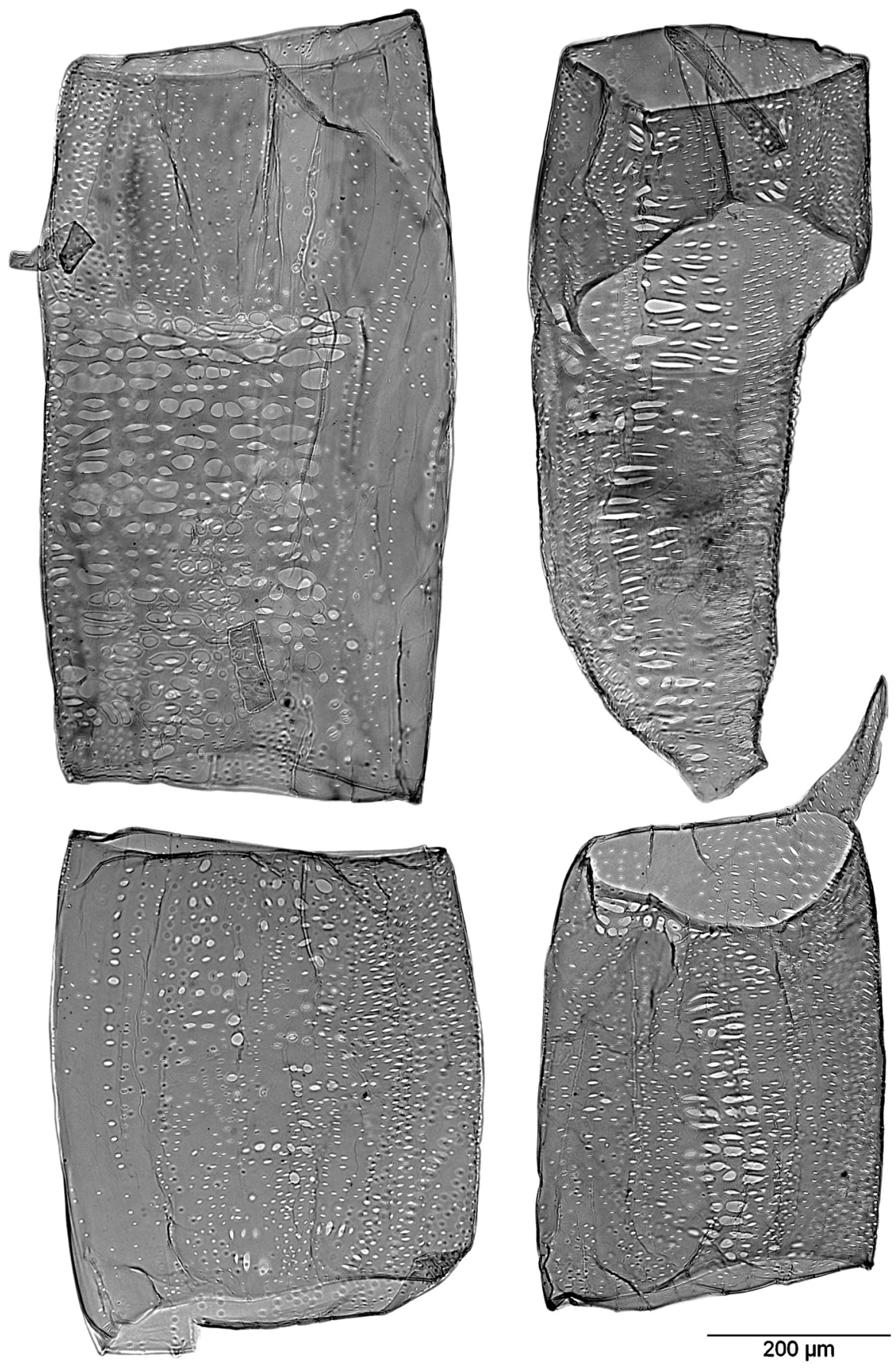

Dipterocarpus sp. 


\section{Dipterocarpus sp. (Dipterocarpaceae)}

Trade names: keruing (ID, MY, DE); yang (FR, TH, VN); gurjun (IN, MM, LK); dau (VN, FR); white kanyin, kanyin-byu (MM); choeuteal (KH); nhang (LA); keroewing (NL); yang hin, yang na (TH); dzao long (VN).

DIN EN 13556:2003 code: DPXX.

CITES regulations: not protected.

Geographic distribution: India, Pakistan, Sri Lanka, Indochina and Western Indomalesia.

Vessel elements: rather large (length about $600 \mu \mathrm{m}$, width about $410 \mu \mathrm{m}$ ); elongated (barrel-shaped), rarely shorter (drum-shaped).

Tails: short with abrupt transition, long with gradual transition or absent.

Perforation plates: simple, extending over the entire lumen; horizontal or slightly inclined.

Intervessel pits: absent (due to vessels being almost exclusively solitary in intact wood).

Vessel-ray pits: VAS; huge variety of size classes and shapes; the larger pits gash-like, the smaller ones circular or oval; cross-fields sometimes covering the entire vessel element wall.

Pits to tracheids: alternate; vertical diameter $2-3-5 \mu \mathrm{m}$; arranged in sinuous strips; sometimes broadened in horizontal direction.

Pits to fibers: present in single vertical rows.

Areas without any pits: regularly present; small to large.

Tyloses: present.

Helical thickenings: absent.

\section{Quantitative data:}

Vessel elements (343-) 601 (-792) $\mu \mathrm{m}$ long, and (294-)409(-480) $\mu \mathrm{m}$ wide; $1 / \mathrm{w}$ ratio 1.4 .

Vessel to tracheid pit borders $(2.3-) 3.3(-5.2) \mu \mathrm{m}$ in vertical diameter; pit apertures $(0.6-) 1.2(-2.5) \mu \mathrm{m}$.

Fibers $1390 \mu \mathrm{m}$ long, $26.5 \mu \mathrm{m}$ wide. Fiber wall thickness $6.1 \mu \mathrm{m}$ (weighted averages). 

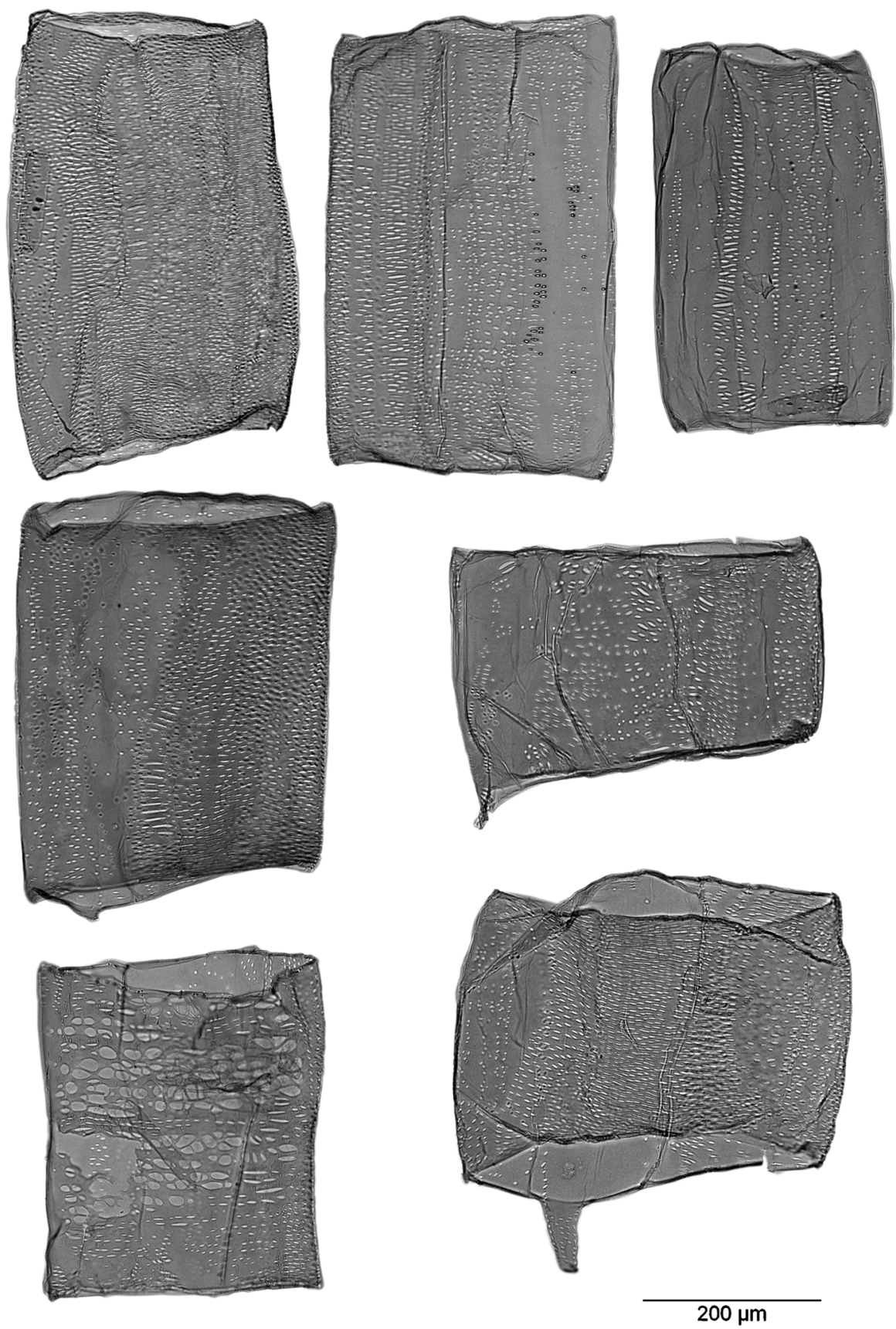

Parashorea sp. 


\section{Parashorea sp. (Dipterocarpaceae)}

Trade names: light wood $\left(0.4-0.6 \mathrm{~g} / \mathrm{cm}^{3}\right)$ : white seraya, white lauan (DE); white seraya, urat mata (MY-sab); seraya puteh (MY-swk); white lauan, bagtikan (PH); pendan (ID). - heavy wood $\left(0.6-0.8 \mathrm{~g} / \mathrm{cm}^{3}\right)$ : heavy white seraya, urat mata batu (MY-sab); gerutu, meranti gerutu (MY); khai kheo, khiansai (TH); thinkadu, tavoy wood (MM); cho chi (VN).

DIN EN 13556: 2003 code: $\mathrm{PHWS} / \mathrm{PHMG}$.

CITES regulations: not protected.

Geographic distribution: Indochina, Indomalesia.

Vessel elements: rather short and wide (length about $430 \mu \mathrm{m}$, width about $370 \mu \mathrm{m}$ ), barrel or drum-shaped, shape well-defined with almost rectangular outlines.

Tails: mostly absent, few long or short tails present with abrupt transition.

Perforation plates: simple, extending over the entire lumen; horizontal.

Intervessel pits: alternate; vertical diameter 2-4-7 $\mu \mathrm{m}$; if present, in large fields over a wide area; apertures oval or sometimes elongated.

Vessel-ray pits: VAS; rarely present; pits window-like or elongated.

Pits to tracheids: in vertical strips (3-5 pit rows), apertures oval to slit-like or gashlike.

Pits to fibers: present in single vertical rows.

Areas without any pits: regularly present; small to sometimes large.

Tyloses: present.

Helical thickenings: absent.

\section{Quantitative data:}

Vessel elements (140-)425(-568) $\mu \mathrm{m}$ long, and (205-)369(-453) $\mu \mathrm{m}$ wide; $1 / \mathrm{w}$ ratio 1.1 .

Intervessel pit borders (1.7-) 3.8(-7.2) $\mu \mathrm{m}$ in vertical diameter; pit apertures (0.5-) $1.1(-3.5) \mu \mathrm{m}$.

Fibers $1145 \mu \mathrm{m}$ long, $19.9 \mu \mathrm{m}$ wide. Fiber wall thickness $3.6 \mu \mathrm{m}$ (weighted averages). 

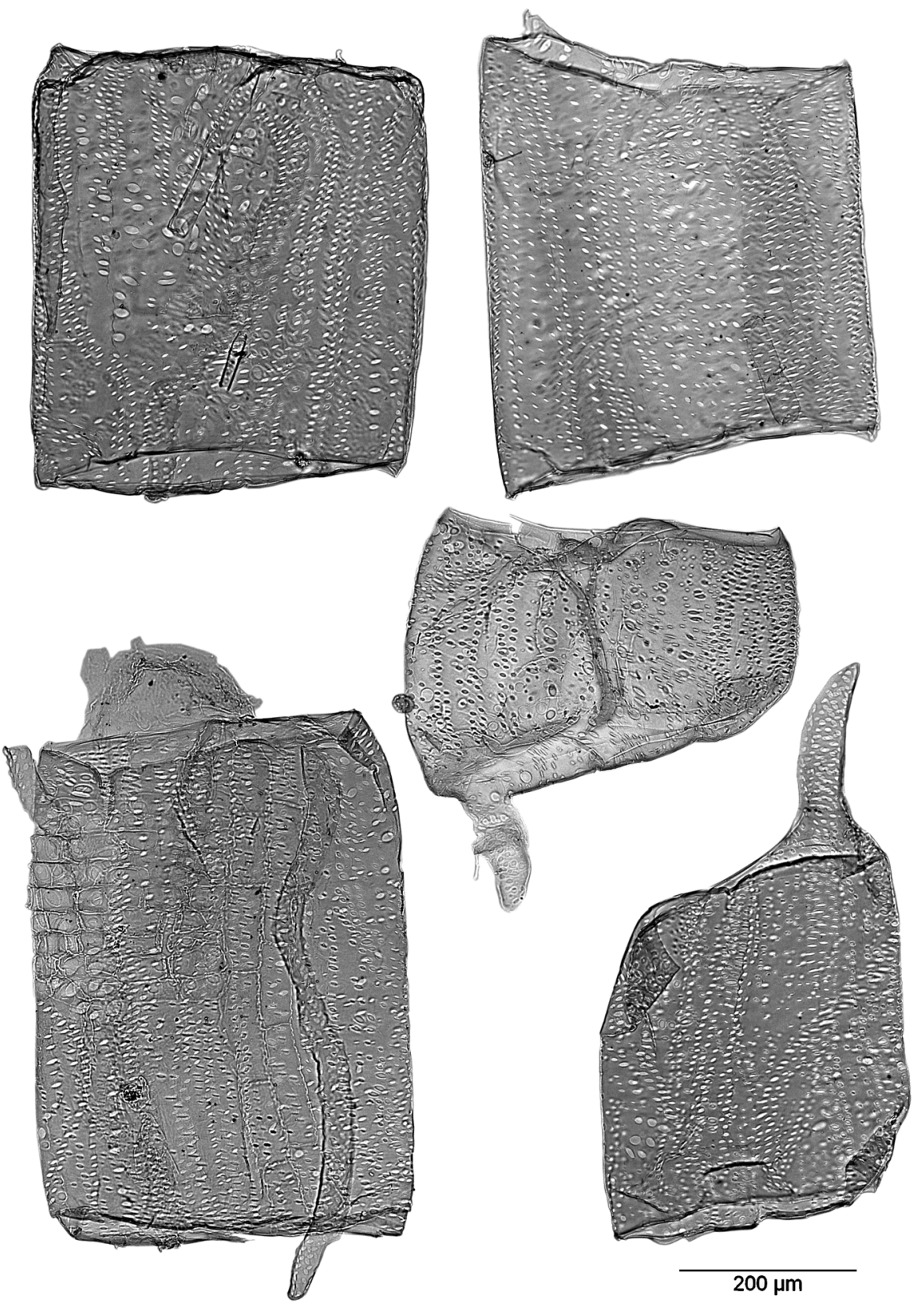

Shorea subg. Anthoshorea 


\section{Shorea subg. Anthoshorea (Dipterocarpaceae)}

Trade names: white meranti (MY, ID); meranti putih, kayu tahan (ID); melapi (MYsab, ID-kal); white lauan (PH); luombor (KH); khiem kha norng, takhian-sai, chai (TH); bo-bo (VN).

DIN EN 13556:2003 code: SHWM.

CITES regulations: not protected.

Geographic distribution: Indochina, Indomalesia.

Vessel elements: average length (about $450 \mu \mathrm{m})$, quite wide $(410 \mu \mathrm{m})$, often barrelshaped and sometimes drum-shaped.

Tails: if present, rather short with abrupt transition or longer with gradual transition.

Perforation plates: simple, extending over the entire lumen; horizontal.

Intervessel pits: alternate; vertical diameter 2-5-8 $\mu \mathrm{m}$; apertures oval.

Vessel-ray pits: VAS; window-like, sometimes elongated; in alternately or separately arranged rows; apertures circular, sometimes elongated.

Pits to axial parenchyma cells: similar in size and shape to vessel-ray pits.

Pits to tracheids: alternate; similar to intervessel pits and pits to fibers, present in sinuous or straight vertical strips of 1-2 pits.

Pits to fibers: present in single vertical rows.

Areas without any pits: if present, rather small.

Tyloses: present.

Helical thickenings: absent.

Notes on identification: The subgenera of Shorea cannot be separated by means of vessel element features as they are of similar appearance.

\section{Quantitative data:}

Vessel elements (244-)453(-645) $\mu \mathrm{m}$ long, and (307-)407(-461) $\mu \mathrm{m}$ wide; 1/w ratio 1.1 .

Intervessel pit borders (2.3-)4.9(-7.7) $\mu \mathrm{m}$ in vertical diameter; pit apertures (0.6-) $1.4(-2.8) \mu \mathrm{m}$.

Fibers $1460 \mu \mathrm{m}$ long, $21.8 \mu \mathrm{m}$ wide. Fiber wall thickness $3.7 \mu \mathrm{m}$ (weighted averages). 


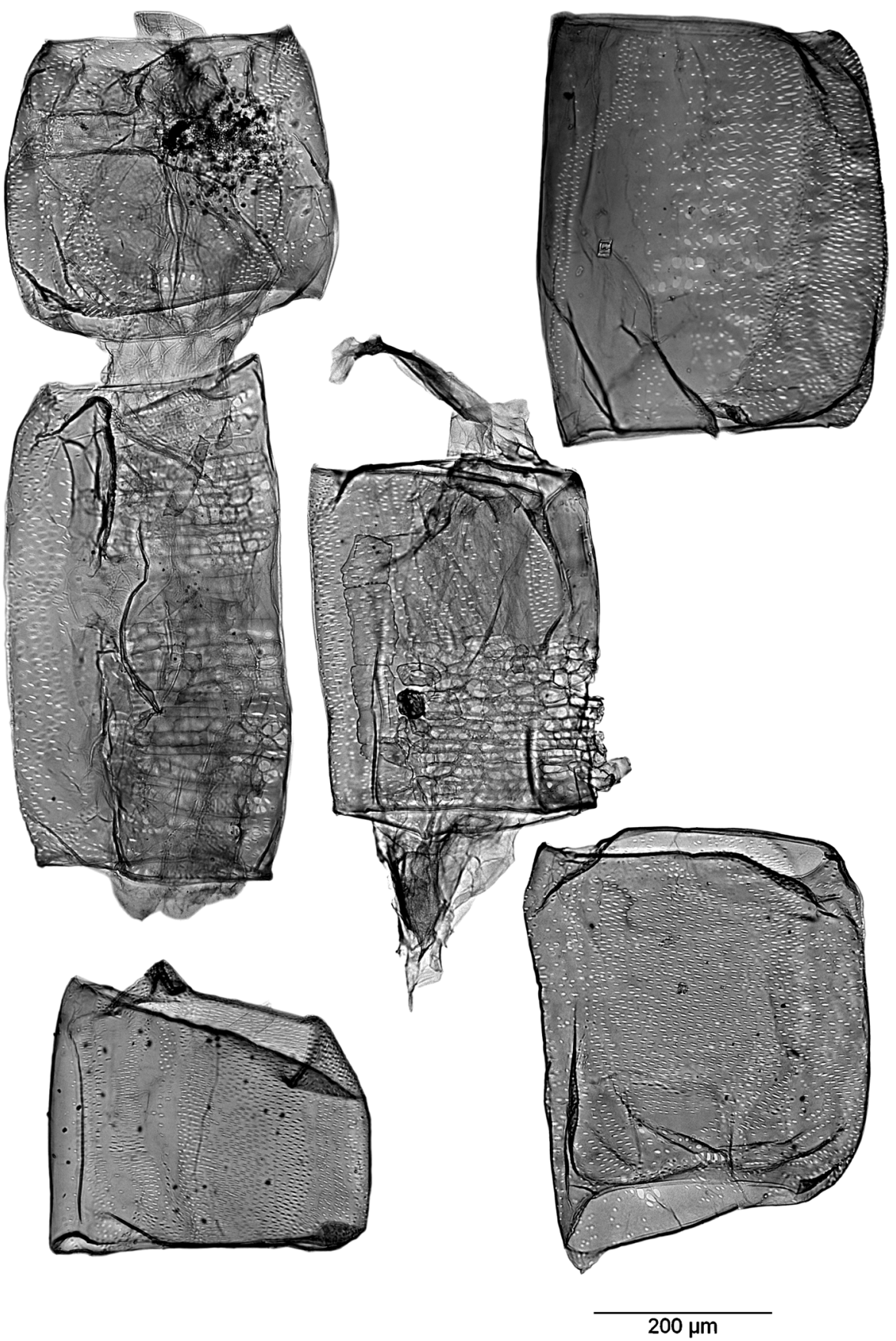

Shorea subg. Richetia 


\section{Shorea subg. Richetia (Dipterocarpaceae)}

Trade names: yellow meranti (MY); yellow seraya (MY-sab); yellow lauan (PH); meranti kuning (ID); meranti damar hitam (MY); selangan kuning, selangan kacha (MY-sab).

DIN EN 13556:2003 code: SHYM.

CITES regulations: not protected.

Geographic distribution: Indomalesia.

Vessel elements: rather short and wide (length about $320 \mu \mathrm{m}$, width about $340 \mu \mathrm{m}$ ), drum or barrel-shaped.

Tails: if present, short with gradual transition.

Perforation plates: simple, extending over the entire lumen; horizontal.

Intervessel pits: alternate; vertical diameter 3-4-9 $\mu \mathrm{m}$; covering large fields over a wide area; apertures oval to slit-like.

Vessel-ray pits: VAS; apertures window-like (rectangular) or oval; of variable size and shape; arranged in one to several rows per ray cell.

Pits to tracheids: forming long vertical strips (3-5 pits wide); apertures elongated.

Pits to fibers: present in single vertical rows.

Areas without any pits: if present, small to large.

Tyloses: often present.

Helical thickenings: absent.

Notes on identification: See Shorea subg. Anthoshorea (p. 314).

\section{Quantitative data:}

Vessel elements (206-)317(-533) $\mu \mathrm{m}$ long, and (251-)344(-413) $\mu \mathrm{m}$ wide; $1 / \mathrm{w}$ ratio 0.9 .

Intervessel pit borders (2.6-) 4.4(-9.3) $\mu \mathrm{m}$ in vertical diameter; pit apertures $(0.5-)$ $1.2(-2.3) \mu \mathrm{m}$.

Fibers $895 \mu \mathrm{m}$ long, $22.0 \mu \mathrm{m}$ wide. Fiber wall thickness $5.2 \mu \mathrm{m}$ (weighted averages). 

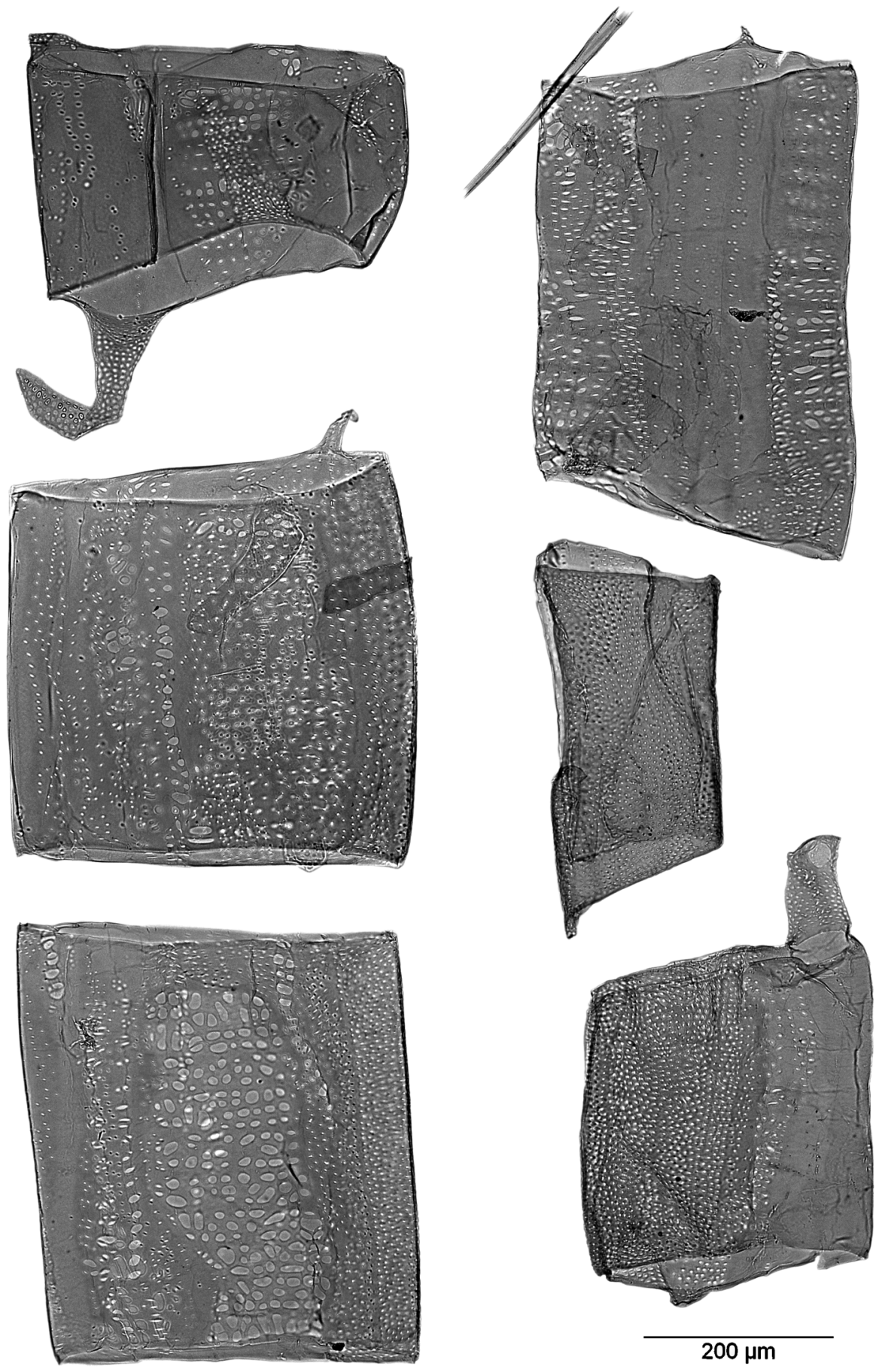

Shorea subg. Rubroshorea 


\section{Shorea subg. Rubroshorea (Dipterocarpaceae)}

Trade names: dark/light red meranti, seraya, lauan (DE); kawang, seraya bunga, red seraya (MY-sab); red lauan (PH); meranti merah (ID).

DIN EN 13556:2003 code: SHDR/SHLR.

CITES regulations: not protected.

Geographic distribution: Indomalesia.

Vessel elements: rather short and wide (length about $380 \mu \mathrm{m}$, width about $310 \mu \mathrm{m}$ ); mainly barrel- or drum-shaped (those with a larger diameter), sometimes tube-shaped (those with a smaller diameter).

Tails: if present, long or short with abrupt transition.

Perforation plates: simple, extending over the entire lumen; horizontal.

Intervessel pits: alternate; vertical diameter 4-7-12 $\mu \mathrm{m}$; present in large fields over a wide area; apertures oval.

Vessel-ray pits: VAS; apertures window-like (more or less circular) or elongated horizontally (gash-like); of variable size and shape; in several rows per ray cell.

Pits to axial parenchyma cells: similar to vessel-ray pits; in narrow vertical bands.

Pits to tracheids: arranged in wide vertical strips; $1-4$ pit rows wide.

Pits to fibers: present in single vertical rows.

Areas without any pits: regularly present; small or large.

Tyloses: often present.

Helical thickenings: absent.

Notes on identification: See Shorea subg. Anthoshorea (p. 314).

\section{Quantitative data:}

Vessel elements (188-)376(-573) $\mu \mathrm{m}$ long, and (139-)312(-421) $\mu \mathrm{m}$ wide; $1 / \mathrm{w}$ ratio 1.2 .

Intervessel pit borders (3.7-) 6.6(-12.2) $\mu \mathrm{m}$ in vertical diameter; pit apertures $(0.8-)$ $1.9(-4.5) \mu \mathrm{m}$.

Fibers $1230 \mu \mathrm{m}$ long, $21.0 \mu \mathrm{m}$ wide. Fiber wall thickness $4.3 \mu \mathrm{m}$ (weighted averages). 

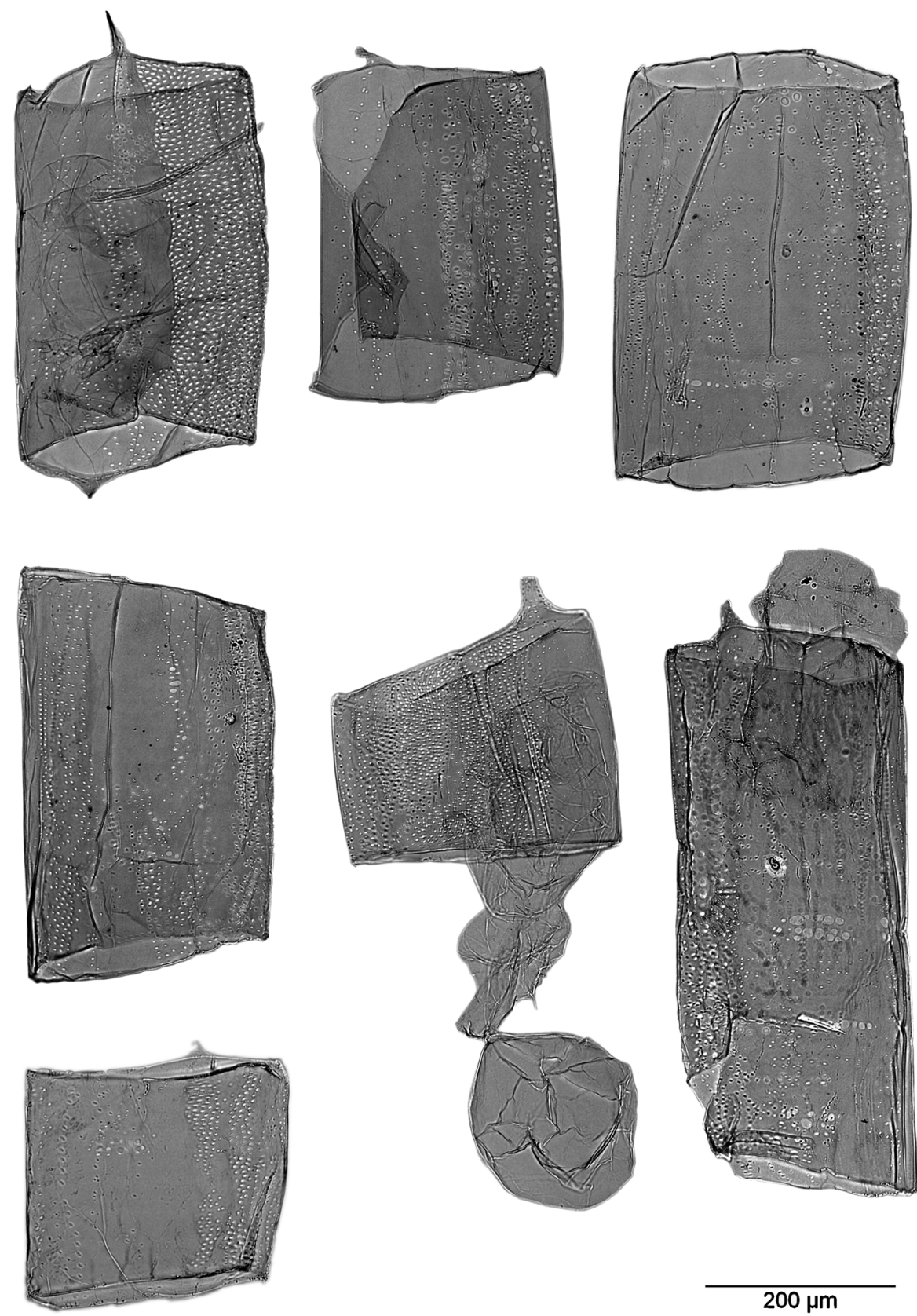

Shorea subg. Shorea 


\section{Shorea subg. Shorea (Dipterocarpaceae)}

Trade names: balau, selangan batu no. 1-no. 2 (MY, DE), selangan batu tatuk, balau bukit, hitam, kumus hitam, laut, laut merah, sengkawang, damar laut (MY), balau bunga, bangkirai, semantok lungkik (ID), yakal (PH), teng (TH), sal (IN).

DIN EN 13556:2003 code: SHRB.

CITES regulations: not protected.

Geographic distribution: India, Pakistan, Sri Lanka, Indochina, Indomalesia.

Vessel elements: rather short (length about $310 \mu \mathrm{m}$, shorter than the other subgenera of Shorea, width about $280 \mu \mathrm{m})$; mostly barrel-shaped, sometimes drum-shaped.

Tails: rather short with abrupt transition, rarely longer with gradual transition.

Perforation plates: simple, extending over the entire lumen; horizontal.

Intervessel pits: alternate; vertical diameter 3-5-9 $\mu \mathrm{m}$; wide fields; apertures oval.

Vessel-ray pits: VAS; apertures circular or oval, rather small; in horizontal rows (1-3 rows per ray cell).

Pits to axial parenchyma cells: similar to vessel-ray pits but somewhat larger; arranged in vertical bands.

Pits to fibers: present in long single vertical rows.

Pits to tracheids: similar to intervessel pits; in vertical strips, 3-5 pits wide.

Areas without any pits: regularly present; small or large.

Tyloses: often present.

Helical thickenings: absent.

Notes on identification: See Shorea subg. Anthoshorea (p. 314).

Quantitative data:

Vessel elements (135-)312(-568) $\mu \mathrm{m}$ long, and (161-) 279(-333) $\mu \mathrm{m}$ wide; $1 / \mathrm{w}$ ratio 1.2.

Intervessel pit borders (2.6-)4.7(-9.4) $\mu \mathrm{m}$ in vertical diameter; pit apertures (0.4-) $1.1(-3.0) \mu \mathrm{m}$.

Fibers $905 \mu \mathrm{m}$ long, $18.2 \mu \mathrm{m}$ wide. Fiber wall thickness $4.7 \mu \mathrm{m}$ (weighted averages). 

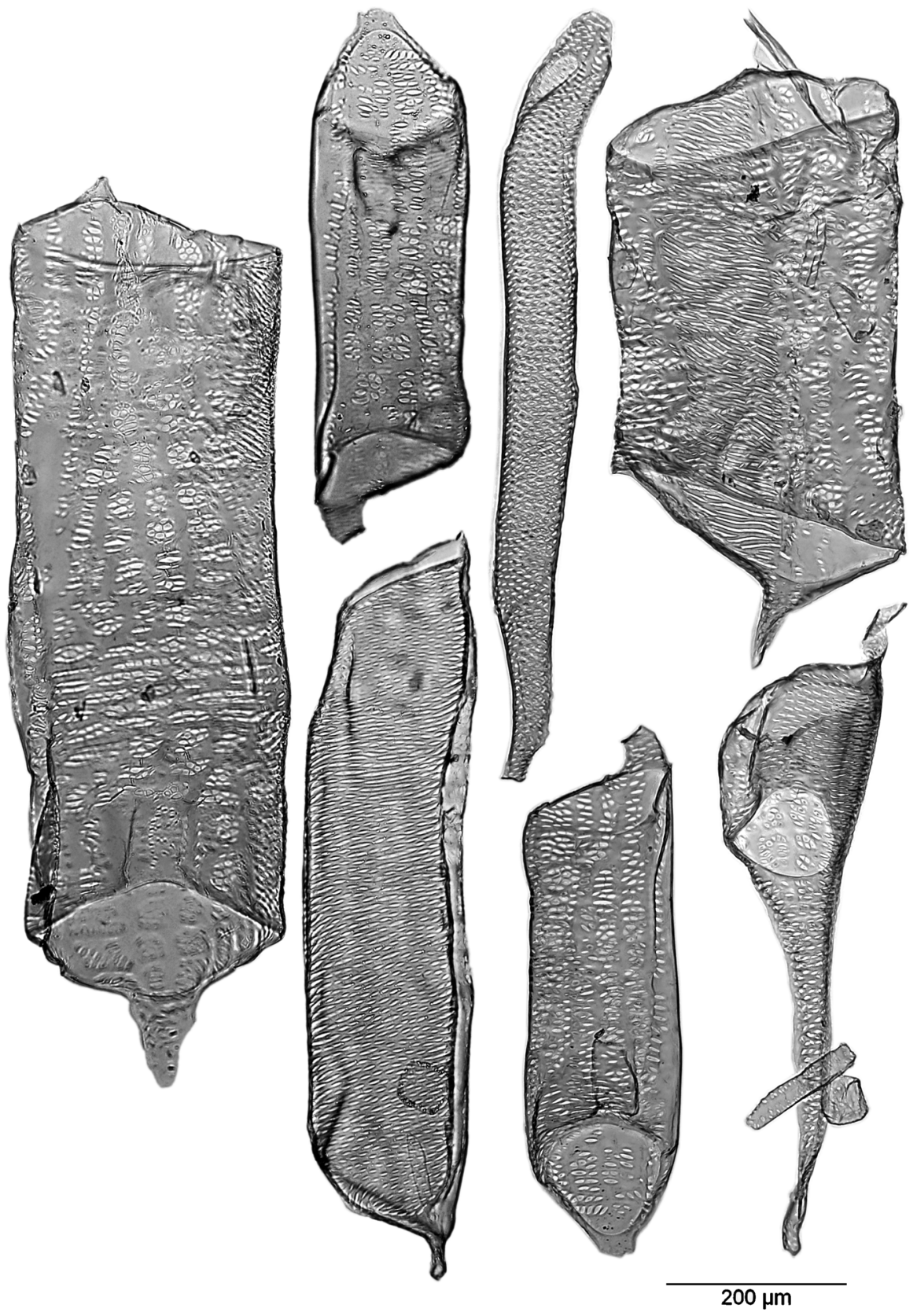

Hevea brasiliensis 


\section{Hevea brasiliensis (Willd. ex A.Juss.) Müll.Arg. (Euphorbiaceae)}

Trade names: rubberwood; hevea (GB, DE, MY, TH, IN); Gummibaum (DE); seringa, seringeira (BR); kayu karet (ID); arbol de caucho (sAM).

DIN EN 13556:2003 code: HVBR.

CITES regulations: not protected.

Geographic distribution: native to tropical South America, widely cultivated in Indomalesia and Africa.

Vessel elements: rather long and often slim (length about $550 \mu \mathrm{m}$, width about $260 \mu \mathrm{m}$ ); mainly tube-shaped (those with a smaller diameter), sometimes barrel-shaped (those with a larger diameter).

Tails: short with abrupt transition or very long with gradual transition.

Perforation plates: simple, extending over the entire lumen; inclined or transverse.

Intervessel pits: alternate; vertical diameter 5-8-12 $\mu \mathrm{m}$; numerous; apertures slit-like, often coalescent; sometimes out of center (irregular appearance).

Vessel-ray pits: VAS; rarely present; window-like (rectangular) or elongated horizontally (gash-like).

Pits to axial parenchyma cells: similar to vessel-ray pits in size and shape; cross-fields well-defined.

Pits to fibers: present in single vertical rows.

Areas without any pits: regularly present; small.

Tyloses: present.

Helical thickenings: absent.

\section{Quantitative data:}

Vessel elements (298-)551 (-854) $\mu \mathrm{m}$ long, and (66-)259(-386) $\mu \mathrm{m}$ wide; $1 / \mathrm{w}$ ratio 2.2 .

Intervessel pit borders (4.6-) 8.1(-11.9) $\mu \mathrm{m}$ in vertical diameter; pit apertures (0.9-) $1.7(-3.3) \mu \mathrm{m}$.

Fibers $1190 \mu \mathrm{m}$ long, $24.4 \mu \mathrm{m}$ wide. Fiber wall thickness $3.1 \mu \mathrm{m}$ (weighted averages). 


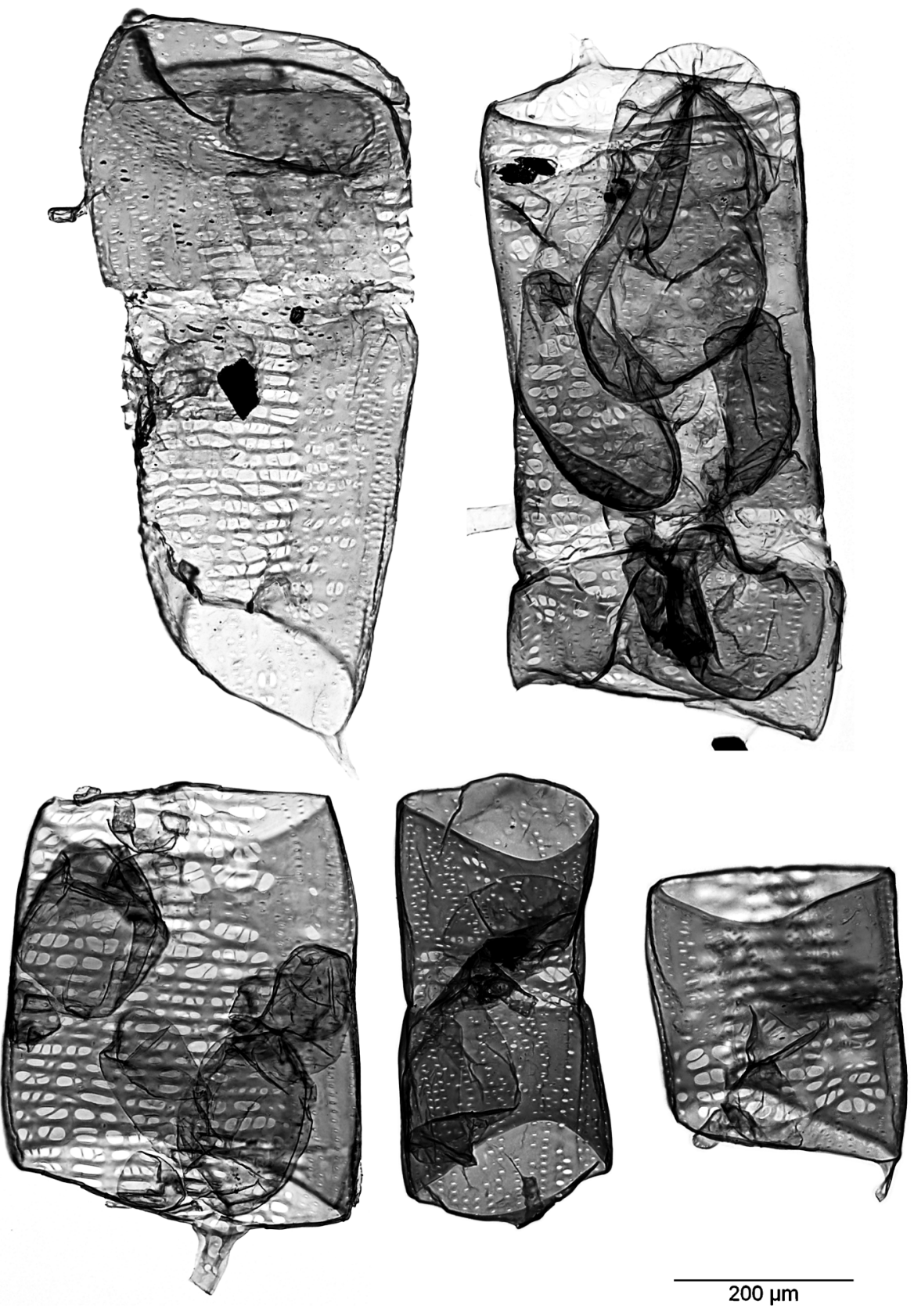

Castanopsis argentea 


\section{Castanopsis argentea (Blume) A. DC. (Fagaceae)}

Trade names: berangan, saninten, New Guinea oak (PG); Malayan chestnut, jertek tangga kata (MY); Philippine chestnut (PH); katia (MM); ko (LA, TH); ko-nam (TH).

DIN EN 13556:2003 code: not listed.

CITES regulations: not protected.

Geographic distribution: Sumatra and Java. (Castanopsis spp.: India, Pakistan, Sri Lanka, Indochina, Indomalesia).

Vessel elements: rather large and wide (length about $480 \mu \mathrm{m}$, width about $310 \mu \mathrm{m}$ ); mainly barrel-shaped (those with a larger diameter), sometimes tube-shaped (those with a smaller diameter).

Tails: short with abrupt transition.

Perforation plates: simple, extending over the entire lumen; horizontal or slightly inclined.

Intervessel pits: absent (due to almost exclusively solitary vessels in intact wood).

Vessel-ray pits: VAS; forming remarkably extensive pitted areas with single, horizontal rows of large to sometimes smaller pits (two size classes).

Pits to fibers: present in single vertical rows.

Pits to tracheids: numerous, arranged in vertical sinuous strips (2-3 pits wide), apertures oval; vertical diameter 5-7-10 $\mu \mathrm{m}$.

Areas without any pits: regularly present; small to large.

Tyloses: present.

Helical thickenings: absent.

Notes on identification: Castanopsis spp. are similar to Lithocarpus spp. and Castanea spp. (not treated in this atlas).

\section{Quantitative data:}

Vessel elements (204-)479(-704) $\mu \mathrm{m}$ long, and (55-)314(-455) $\mu \mathrm{m}$ wide; $1 / \mathrm{w}$ ratio 1.6.

Vessel to tracheid pit borders (4.5-)7.1(-10.3) $\mu \mathrm{m}$ in vertical diameter; pit apertures $(0.5-) 1.2(-3.5) \mu \mathrm{m}$.

Fibers $1160 \mu \mathrm{m}$ long, $22.7 \mu \mathrm{m}$ wide. Fiber wall thickness $2.8 \mu \mathrm{m}$ (weighted averages). 

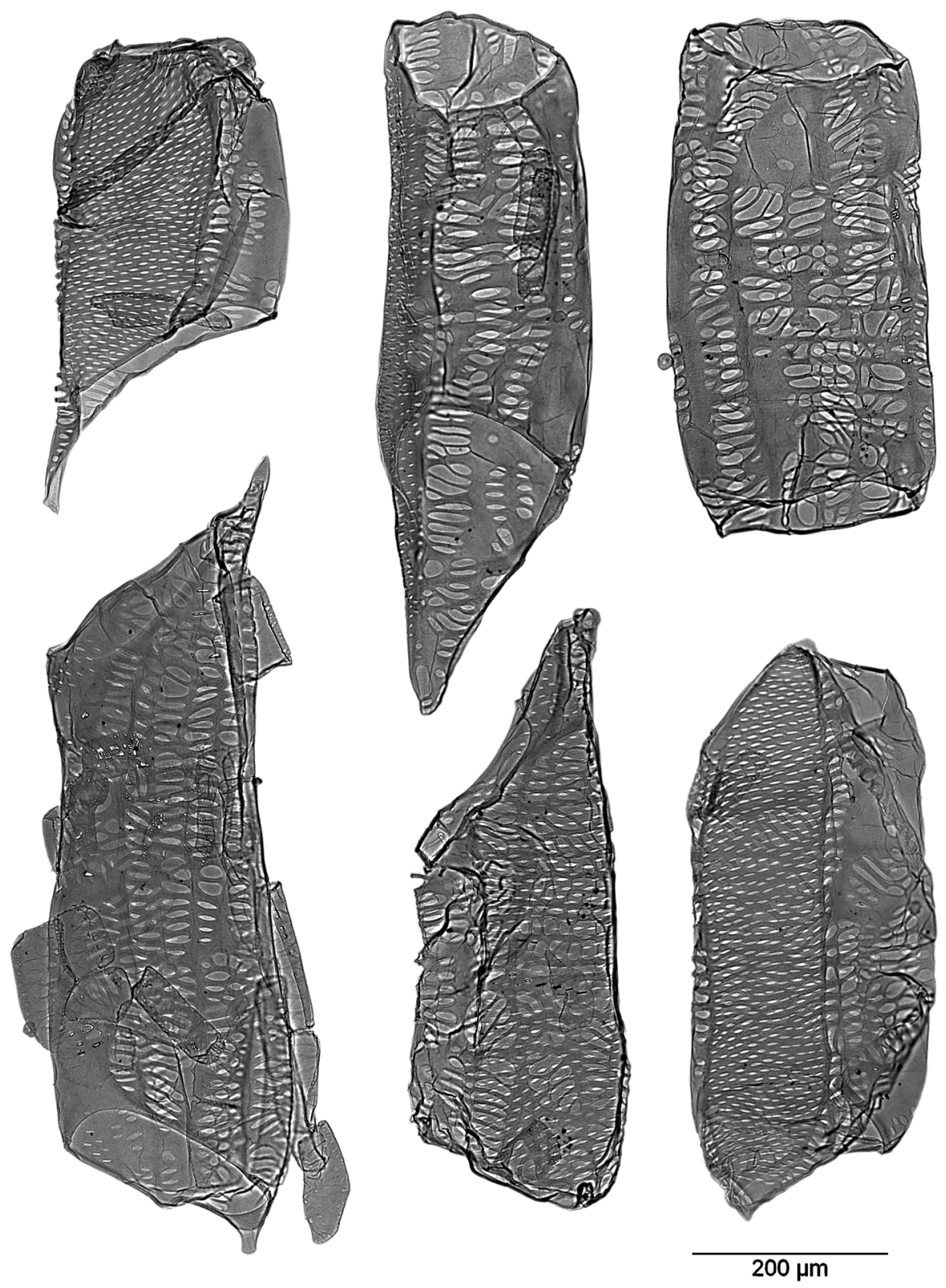

Litsea resinosa 


\section{Litsea resinosa Blume (Lauraceae)}

Trade name: medang (ID, MY).

DIN EN 13556:2003 code: not listed.

CITES regulations: not protected.

Geographic distribution: Java, Borneo, Peninsular Malaysia.

Vessel elements: rather long (length about $490 \mu \mathrm{m}$, width about $240 \mu \mathrm{m}$ ); mainly barrel-shaped.

Tails: long or short with gradual transition.

Perforation plates: simple; extending over the entire lumen; inclined (parallelogram or trapezium-shaped) to horizontal. Sometimes with tapering end walls.

Intervessel pits: alternate; vertical diameter 5-8-12 $\mu \mathrm{m}$; covering wide areas and the tails; apertures slit-like.

Vessel-ray pits: VAS; quite large, window-like, circular or elongated horizontally (gash-like), sometimes vertically (palisade).

Pits to axial parenchyma cells: similar to vessel-ray pits in size and shape.

Pits to fibers: present in longitudinal single rows.

Areas without any pits: regularly present; small to large.

Tyloses: present.

Helical thickenings: absent.

Notes on identification: vessel element features of this species resemble those of some Anacardiaceae but vessel-ray pits are larger and arranged in more well-defined blocks.

\section{Quantitative data:}

Vessel elements (290-) 486(-671) $\mu \mathrm{m}$ long, and (173-) 242(-303) $\mu \mathrm{m}$ wide; $1 / \mathrm{w}$ ratio 2.0 .

Intervessel pit borders (5.0-) 7.8(-12.0) $\mu \mathrm{m}$ in vertical diameter; pit apertures (0.7-) $1.8(-3.4) \mu \mathrm{m}$.

Fibers $1055 \mu \mathrm{m}$ long, $26.3 \mu \mathrm{m}$ wide. Fiber wall thickness $6.7 \mu \mathrm{m}$ (weighted averages). 


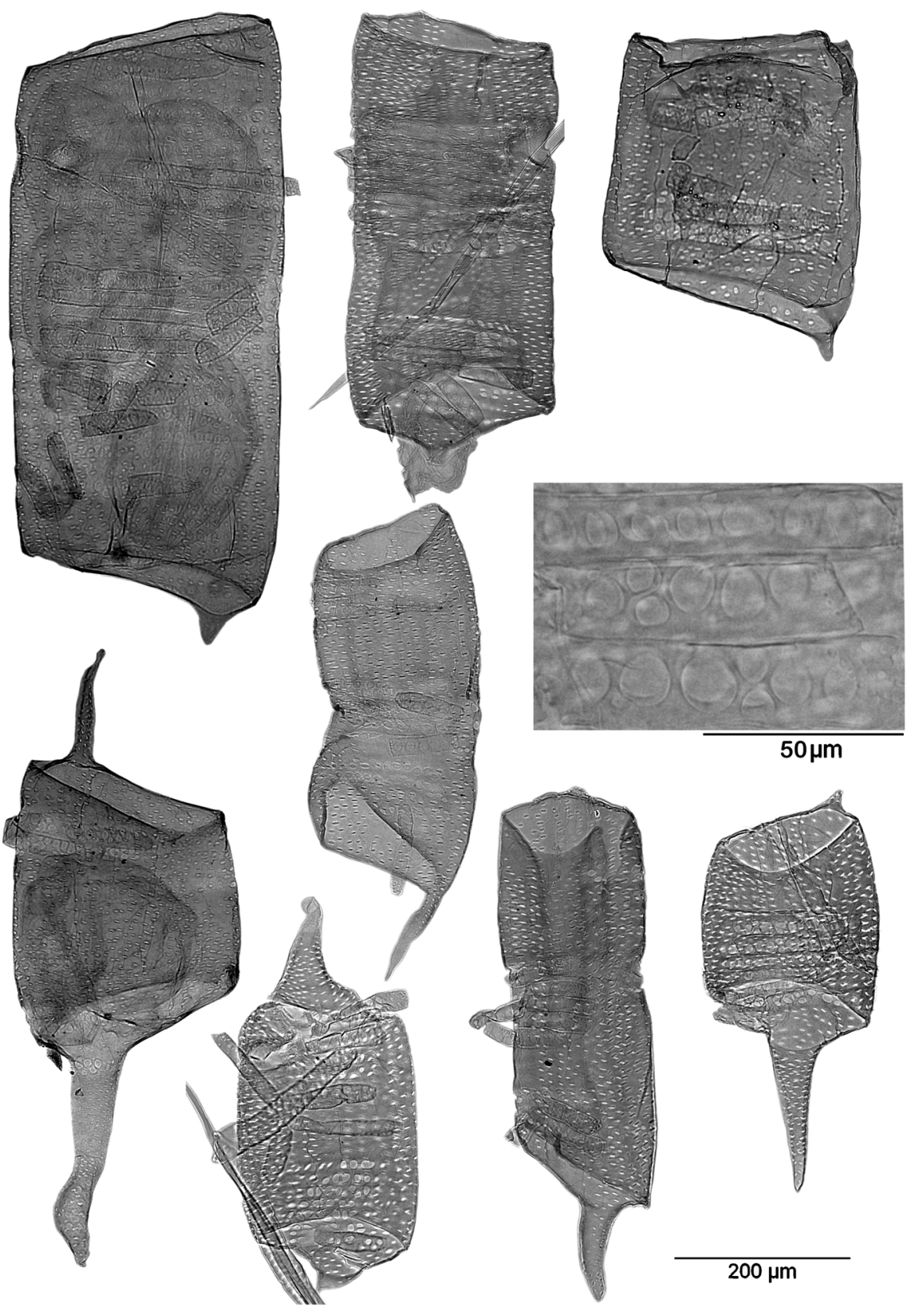

Eucalyptus globulus 


\section{Eucalyptus globulus Labill. (Myrtaceae)}

Trade names: blue gum, Tasmanian blue-gum, southern blue-gum (AU).

DIN EN 13556: 2003 code: EUGL.

CITES regulations: not protected.

Geographic distribution: native to Australia; introduced in many countries, most notably in the Mediterranean, North Africa, Southwest Asia, South Africa, North America, Temperate South America.

Eucalyptus spp. plantations provide short fiber raw material for the pulp and paper industry.

Vessel elements: slim (length about $310 \mu \mathrm{m}$, width about $240 \mu \mathrm{m}$ ); barrel or tubeshaped.

Tails: long with gradual or abrupt transition or short with abrupt transition.

Perforation plates: simple, extending over the entire lumen; horizontal or slightly inclined.

Intervessel pits: very rarely present; alternate; vertical diameter 3-5-9 $\mu \mathrm{m}$; arranged in fields; present in the tails; similar in size and shape to pits to tracheids; apertures slit-like.

Vessel-ray pits: VAS; large apertures circular to oval (see detail in box); sometimes with adhering parenchyma cells.

Pits to tracheids: in vertical strips 2-3 pits wide.

Pits to fibers: regularly present in single vertical rows.

Areas without any pits: if present, rather small.

Tyloses: present.

Helical thickenings: absent.

\section{Quantitative data:}

Vessel elements (182-)309(-615) $\mu \mathrm{m}$ long, and (160-) 243(-358) $\mu \mathrm{m}$ wide; $1 / \mathrm{w}$ ratio 1.4 .

Intervessel pit borders (3.1-)5.2(-8.8) $\mu \mathrm{m}$ in vertical diameter; pit apertures (0.6-) $1.4(-3.4) \mu \mathrm{m}$.

Fibers $800 \mu \mathrm{m}$ long, $18.9 \mu \mathrm{m}$ wide. Fiber wall thickness $6.0 \mu \mathrm{m}$ (weighted averages). 


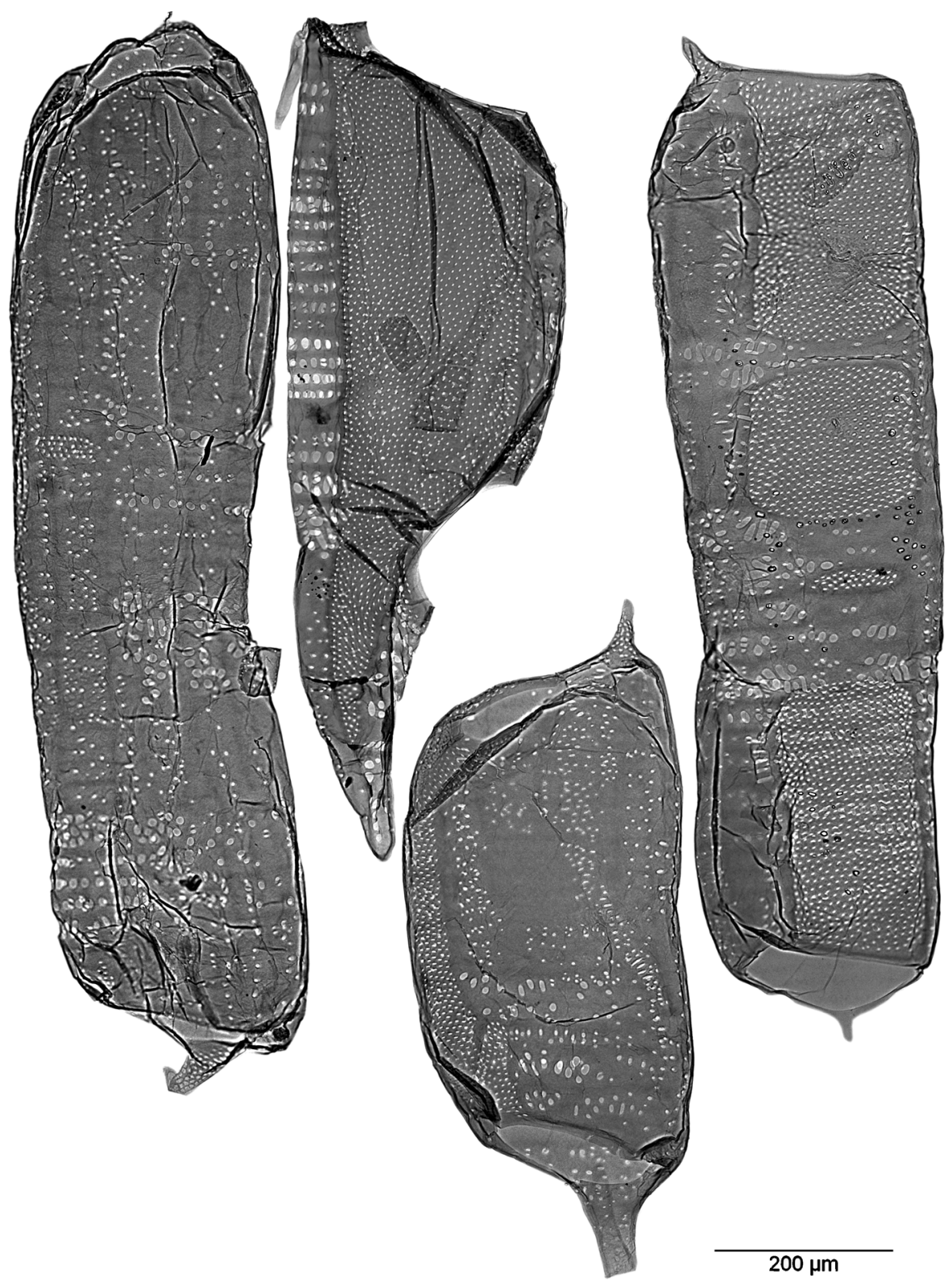

Syzygium dyerianum 


\section{Syzygium dyerianum (King) Chantaran. \& J. Parn. (Myrtaceae)}

Trade name: kelat (MY).

DIN EN 13556:2003 code: not listed.

CITES regulations: not protected.

Geographic distribution: Thailand, Peninsular Malaysia.

Vessel elements: quite large and elongated (length about $760 \mu \mathrm{m}$, width about 290 $\mu \mathrm{m})$; often tube-like, sometimes barrel-shaped.

Tails: long with gradual transition or short with abrupt transition.

Perforation plates: simple; slightly narrowed, slightly inclined or horizontal.

Intervessel pits: alternate; vertical diameter 3-6-8 $\mu \mathrm{m}$; forming fields covering a wide area; also in the tails; apertures circular to oval.

Vessel-ray pits: VAS; distributed over a great part of the vessel element wall; arranged in exact horizontal rows; window-like circular to oval apertures or extended diagonally, giving rise to a reticulate pattern in cross fields.

Pits to axial parenchyma cells: in vertically oriented blocks, with circular apertures.

Areas without any pits: regularly present; small to large.

Tyloses: present.

Helical thickenings: absent.

Notes on identification: the vessel element features are in part similar to those observed in species of Dipterocarpaceae.

\section{Quantitative data:}

Vessel elements (278-)763(-1104) $\mu \mathrm{m}$ long, and (167-)285(-367) $\mu \mathrm{m}$ wide; $1 / \mathrm{w}$ ratio 2.7 .

Intervessel pit borders (2.5-) 5.7(-8.0) $\mu \mathrm{m}$ in vertical diameter; pit apertures (0.7-) $1.6(-3.1) \mu \mathrm{m}$.

Fibers $1345 \mu \mathrm{m}$ long, $28.8 \mu \mathrm{m}$ wide. Fiber wall thickness $8.8 \mu \mathrm{m}$ (weighted averages). 

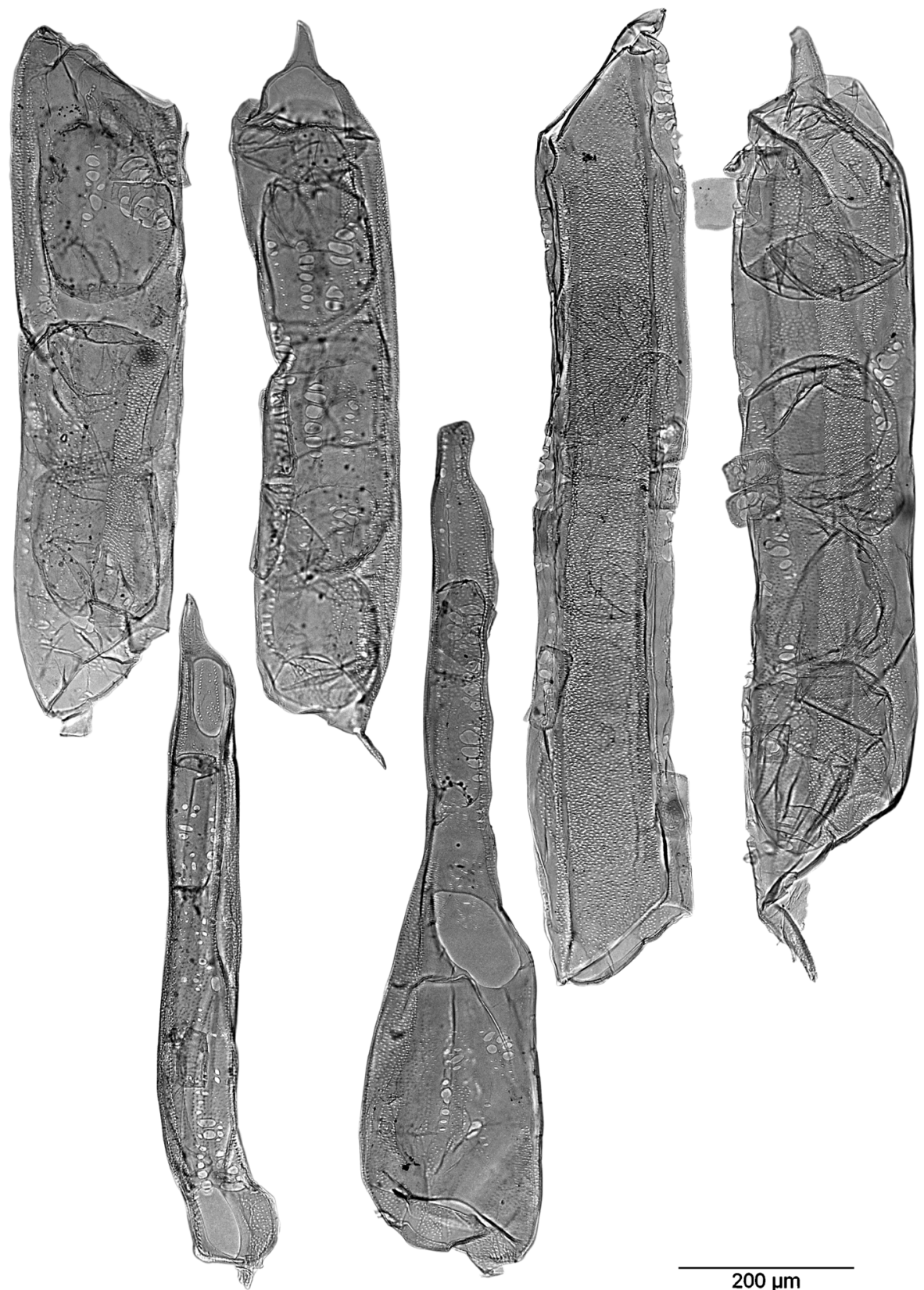

Madhuca sericea 


\section{Madhuca sericea (Miq.) S. Moore (Sapotaceae)}

Trade names: bitis, nyatoh batu (MY, ID).

DIN EN 13556:2003 code: MDXX (Madhuca spp.).

CITES regulations: not protected.

Geographic distribution: Peninsular Malaysia, Sumatra, Borneo. (Madhuca spp: India, Pakistan, Sri Lanka, Indochina, Indomalesia, Pacific Islands).

Vessel elements: long and slim (length about $730 \mu \mathrm{m}$, width about $170 \mu \mathrm{m}$ ); tubeshaped.

Tails: very long with gradual transition or short with abrupt or gradual transition.

Perforation plates: simple, often extending over the entire lumen; inclined.

Intervessel pits: alternate; vertical diameter 2-3-5 $\mu \mathrm{m}$; numerous; large fields covering a wide area of the vessel element wall; also in the tails; apertures oval.

Vessel-ray pits: VAS; apertures window-like, circular to oval to elongated horizontally (gash-like); irregularly shaped.

Pits to axial parenchyma cells: similar to vessel-ray pits in size and shape.

Pits to tracheids: if present, in longitudinal well-defined strips (6-8 pits wide); similar to intervessel pits.

Pits to fibers: present in longitudinal single rows.

Areas without any pits: regularly present; large to very large.

Tyloses: often present.

Helical thickenings: absent.

Quantitative data:

Vessel elements (310-)725(-1103) $\mu \mathrm{m}$ long, and (84-) $168(-196) \mu \mathrm{m}$ wide; $1 / \mathrm{w}$ ratio 4.2.

Intervessel pit borders $(1.8-) 3.0(-4.9) \mu \mathrm{m}$ in vertical diameter; pit apertures $(0.5-)$ $0.8(-1.5) \mu \mathrm{m}$.

Fibers $1485 \mu \mathrm{m}$ long, $27.5 \mu \mathrm{m}$ wide. Fiber wall thickness $7.7 \mu \mathrm{m}$ (weighted averages). 

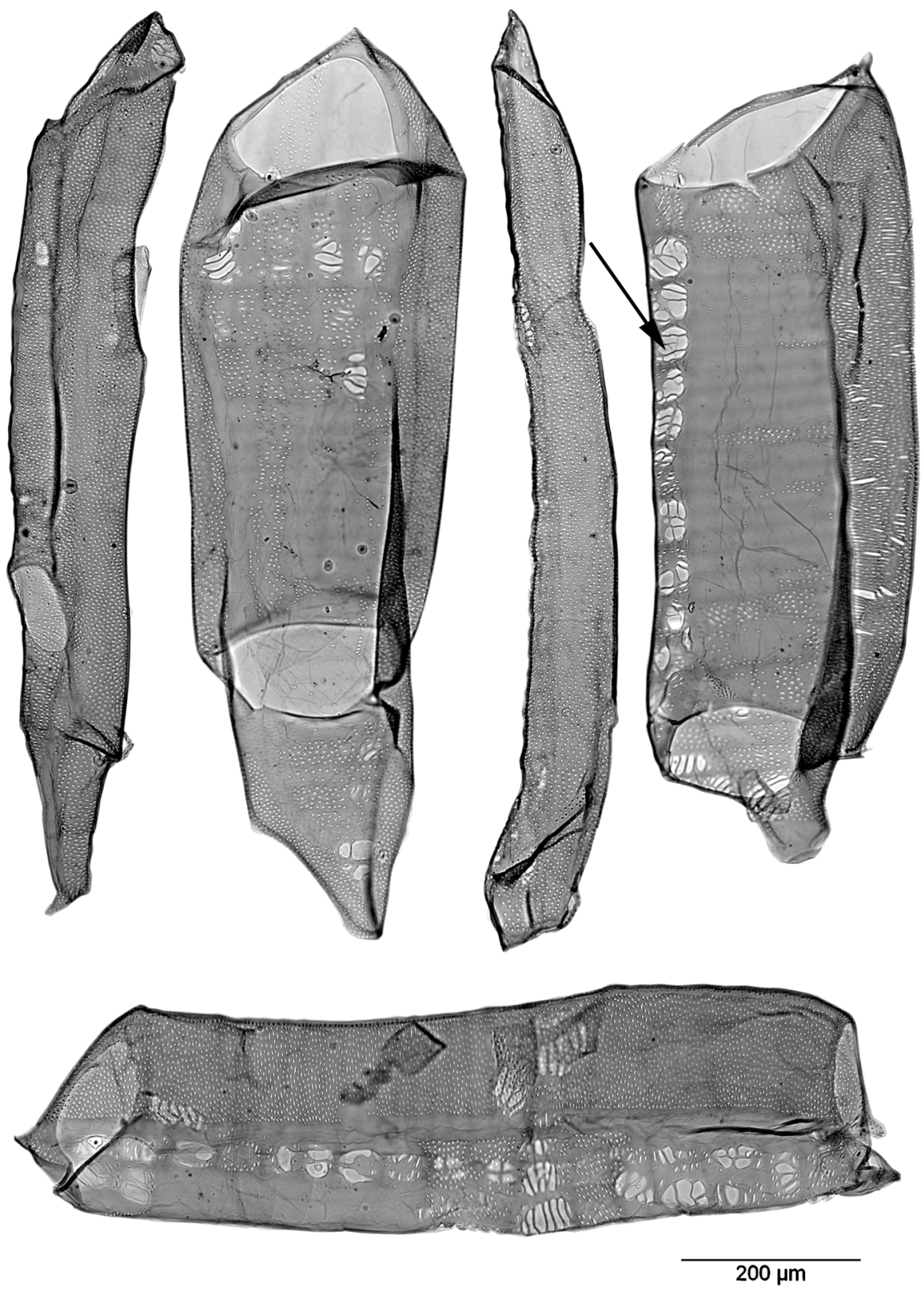

Palaquium sp. 


\section{Palaquium sp. (Sapotaceae)}

Trade names: nyatoh (MY, ID, DE); chay (VN); pencil cedar, red planchonella (PG); pali (IN); nato (PH); kha-nunnok (TH); riam jangka (MY-swk); hangkang, balam teruing puteh, balam masin, kayu tanjung hutan, mayang, taban (MY, ID); moordooke (AU).

DIN EN 13556: 2003 code: PPXX.

CITES regulations: not protected.

Geographic distribution: India, Sri Lanka, South China, Indochina, Indomalesia and Pacific Islands.

Vessel elements: large (length about $690 \mu \mathrm{m}$, width $290 \mu \mathrm{m}$ ); elongated: those with a smaller diameter are tube-shaped; those with a larger diameter are barrel-shaped.

Tails: short to very long, with gradual transition.

Perforation plates: simple or very rarely scalariform (with 3-10 bars, Richter \& Dallwitz 2000); extending over the entire lumen; inclined; few positioned laterally.

Intervessel pits: regularly present; alternate; vertical diameter $3-5-8 \mu \mathrm{m}$; large areas with numerous intervessel pits; apertures circular to oval.

Vessel-ray pits: VAS; in two size classes: larger ones mostly elongated, in groups of 4-8 pits per ray cell (arrow); smaller ones similar to intervessel pits, cross-fields with 3-5 pit rows; apertures oval.

Areas without any pits: regularly present; large to very large.

Tyloses: present.

Helical thickenings: absent.

\section{Quantitative data:}

Vessel elements (434-) 691 (-846) $\mu \mathrm{m}$ long, and (132-) 292(-406) $\mu \mathrm{m}$ wide; $1 / \mathrm{w}$ ratio 2.4 .

Intervessel pit borders (3.1-)4.9(-7.8) $\mu \mathrm{m}$ in vertical diameter; pit apertures (0.6-) $1.2(-\beta 2.0) \mu \mathrm{m}$.

Fibers $1900 \mu \mathrm{m}$ long, $27.5 \mu \mathrm{m}$ wide. Fiber wall thickness $6.6 \mu \mathrm{m}$ (weighted averages). 


\section{Hardwoods with scalariform perforation plates}

introductory comments

This chapter deals with six wood species that possess exclusively scalariform perforation plates. The monocot Cocos nucifera (p. 270) also has scalariform perforations. The bars can be thick or thin and differ in number (Fig. 15). These genera could also be included in the groups of APS (p. 272) and VAS (p. 296) but the highly diagnostic feature of the scalariform perforation plates justifies assigning them to a separate group.

There are some genera in the VAS group (p.296) that, according to literature reports, occasionally have scalariform perforation plates (Campnosperma sp. (p. 298) and Palaquium sp. (p. 334)).

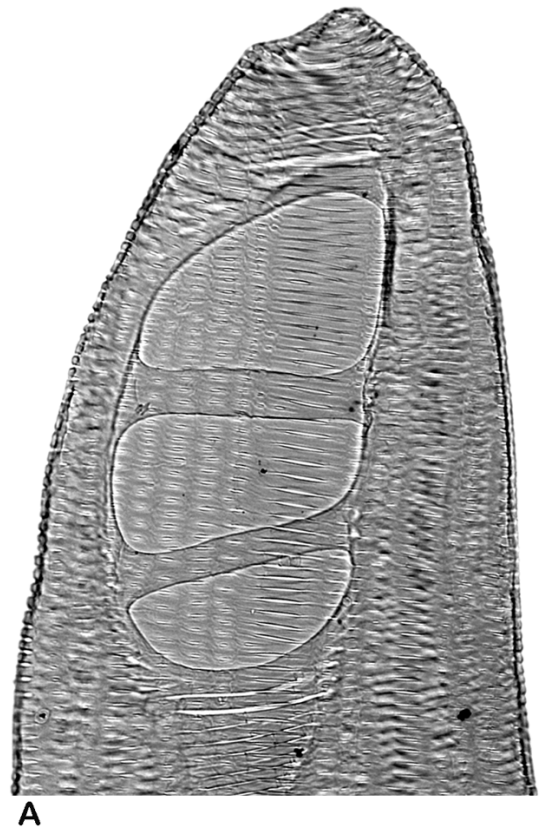

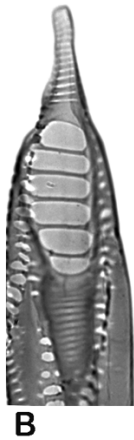

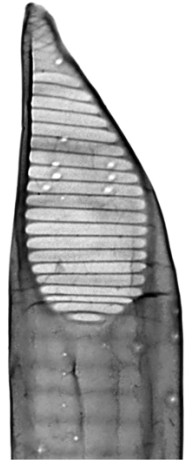

C

$200 \mu \mathrm{m}$

Figure 15. Scalariform perforation plates.

A: 2-4 thick bars, Cocos nucifera. - B: 3-10 thin bars, Rhizophora sp. - C: 15-30 thin bars, Liquidambar formosana.

Figure 16 shows the variation of vessel element length and width as well as the diameter of the apertures and borders of intervessel pits. The boxplots of the length show similar dimensions for Alniphyllum pterospermum, Ilex triflora, Liquidambar formosana and Schima superba (Fig. 16a) whereas the values of the width vary (Fig. 16b). Nyssa javanica possesses the longest and widest vessel elements and Rhizophora sp. the shortest ones. The apertures of intervessel pits of all six species are of similar size with small deviations, the vertical diameters of the pit borders are correspondingly larger. 

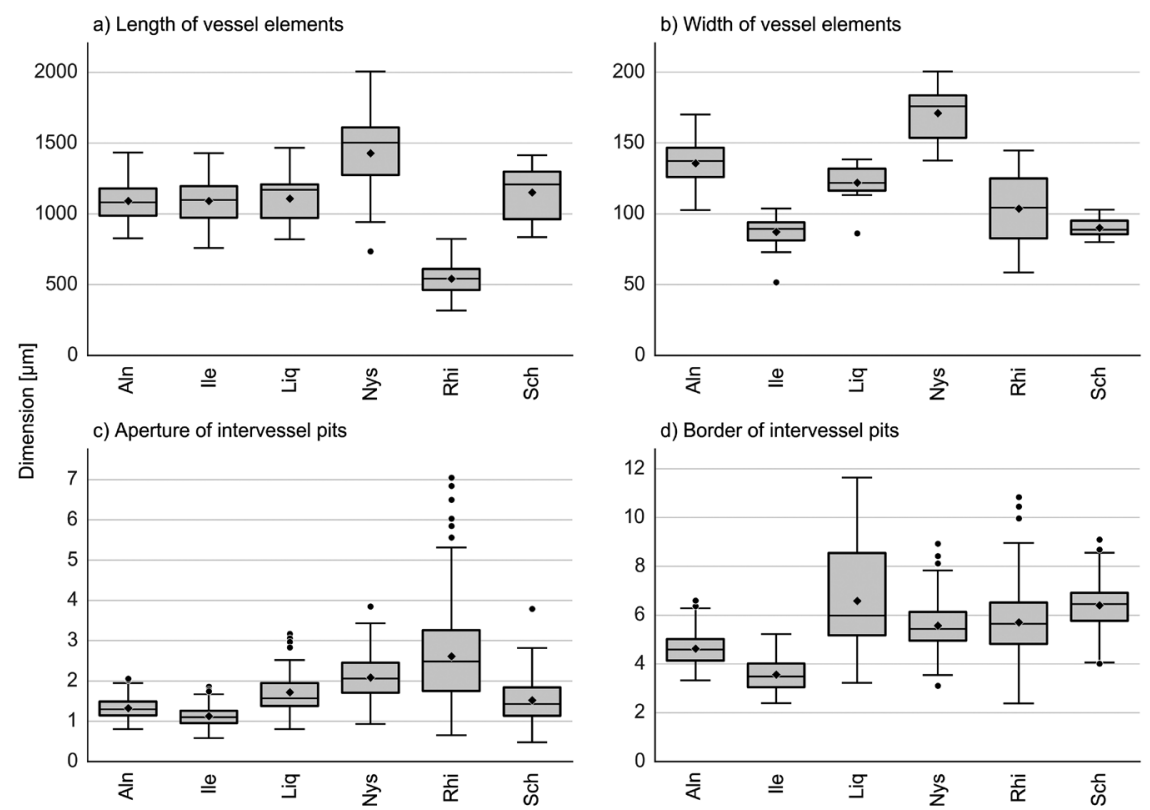

Figure 16. Boxplots of six wood genera/species (length and width of the vessel elements, diameter of pit apertures and borders):

Aln = Alniphyllum pterospermum; Ile = Ilex triflora var. kanehirai $;$ Liq = Liquidambar formosana; Nys $=$ Nyssa javanica $;$ Rhi $=$ Rhizophora sp.; Sch = Schima superba .

Table 2, a comparison of the eight species with scalariform perforation plates, shows similarities and major differences.

Vessel elements of Nyssa spp. are similar to those of Liriodendron spp. and Alniphyllum spp. Nyssa spp. have more numerous thin bars and opposite intervessel pits that distinguish them from Liquidambar spp. and Schima spp. (see notes on identifications at the end of the individual species descriptions). Rhizophora stands out with very extensive scalariform intervessel pits.

Table 2. Species with scalariform perforation plates.

\begin{tabular}{lccccc}
\hline Species & $\begin{array}{c}\text { Length of } \\
\text { vessel elements } \\
(\mu \mathrm{m})\end{array}$ & $\begin{array}{c}\text { Number } \\
\text { of bars }\end{array}$ & Intervessel pits & $\begin{array}{c}\text { Size of } \\
\text { intervessel } \\
\text { pits }(\mu \mathrm{m})\end{array}$ & $\begin{array}{c}\text { Pits to ray } \\
\text { parenchyma } \\
\text { cells }\end{array}$ \\
\hline Alniphyllum & $830-1080-1430$ & $8-15$ & Opposite/alternate & $3-5-7$ & APS \\
Cocos & $1450-2840-4330$ & $2-4$ & Scalariform & - & - \\
Ilex & $760-1100-1430$ & $20-40$ & Opposite & $2-4-5$ & APS \\
Liquidambar & $820-1170-1470$ & $15-30$ & Scalariform & $3-6-12$ & VAS \\
Liriodendron* & - & $3-5-10$ & Scalariform/opposite & $10-11$ & VAS \\
Nyssa & $740-1500-2000$ & $20-30(-50)$ & Opposite/scalariform & $3-5-9$ & VAS \\
Rhizophora & $320-540-820$ & $3-10$ & Scalariform & $2-6-11$ & VAS \\
Schima & $840-1210-1410$ & $5-15$ & Scalariform & $4-7-9$ & VAS \\
\hline
\end{tabular}

* Liriodendron is not treated in this atlas but is commonly used for pulp and paper from North America and temperate China (data: Richter \& Dallwitz 2000). 


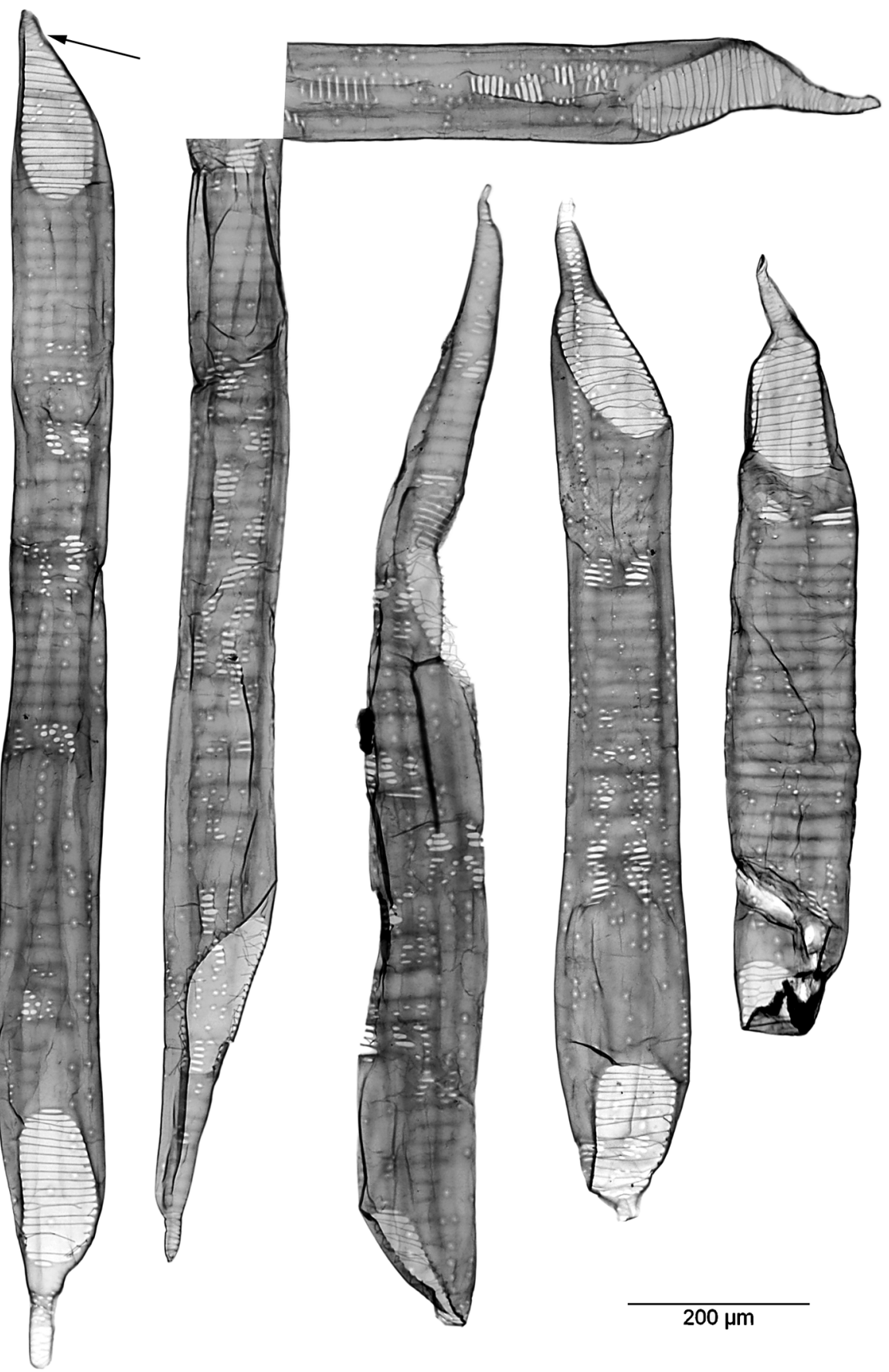

Liquidambar formosana 


\section{Liquidambar formosana Hance (Altingiaceae)}

Trade names: Chinese sweet gum, Formosan sweet gum (US), feng xiang shu (CN). DIN EN 13556:2003 code: LQST (Liquidambar styraciflua L.).

CITES regulations: not protected.

Geographic distribution: China and Indochina. (Liquidambar spp.: temperate Asia (L.formosana), North America, Mexico and Central America).

Vessel elements: quite long and slim (length about $1170 \mu \mathrm{m}$, width about $120 \mu \mathrm{m}$ ), tube-shaped.

Tails: short or long, with gradual transition.

Perforation plates: scalariform (15-30 thin bars); extending over the entire lumen; inclined.

Intervessel pits: rarely present; vertical diameter 3-6-12 $\mu \mathrm{m}$; scalariform.

Vessel-ray pits: VAS; oval or elongated horizontally (gash-like); giving rise to a scalariform pattern in the cross-fields.

Pits to fibers: often present in single vertical rows.

Areas without any pits: regularly present; large.

Tyloses: present.

Helical thickenings: sometimes present at the end of the tails (arrow).

Notes on identification: Vessel elements of Liquidambar spp. are similar to those of Schima spp. but the number of bars differs (Liquidambar spp. 15-30 bars, Schima spp. 5-15 bars). They cannot be easily distinguished in mixed pulp.

\section{Quantitative data:}

Vessel elements (822-)1172(-1467) $\mu \mathrm{m}$ long, and (86-)122(-138) $\mu \mathrm{m}$ wide; $1 / \mathrm{w}$ ratio 9.4.

Intervessel pit borders (3.2-)6.0(-11.6) $\mu \mathrm{m}$ in vertical diameter; pit apertures $(0.8-)$ $1.6(-3.2) \mu \mathrm{m}$.

Fibers $1720 \mu \mathrm{m}$ long, $27.3 \mu \mathrm{m}$ wide. Fiber wall thickness $2.8 \mu \mathrm{m}$ (weighted averages). 

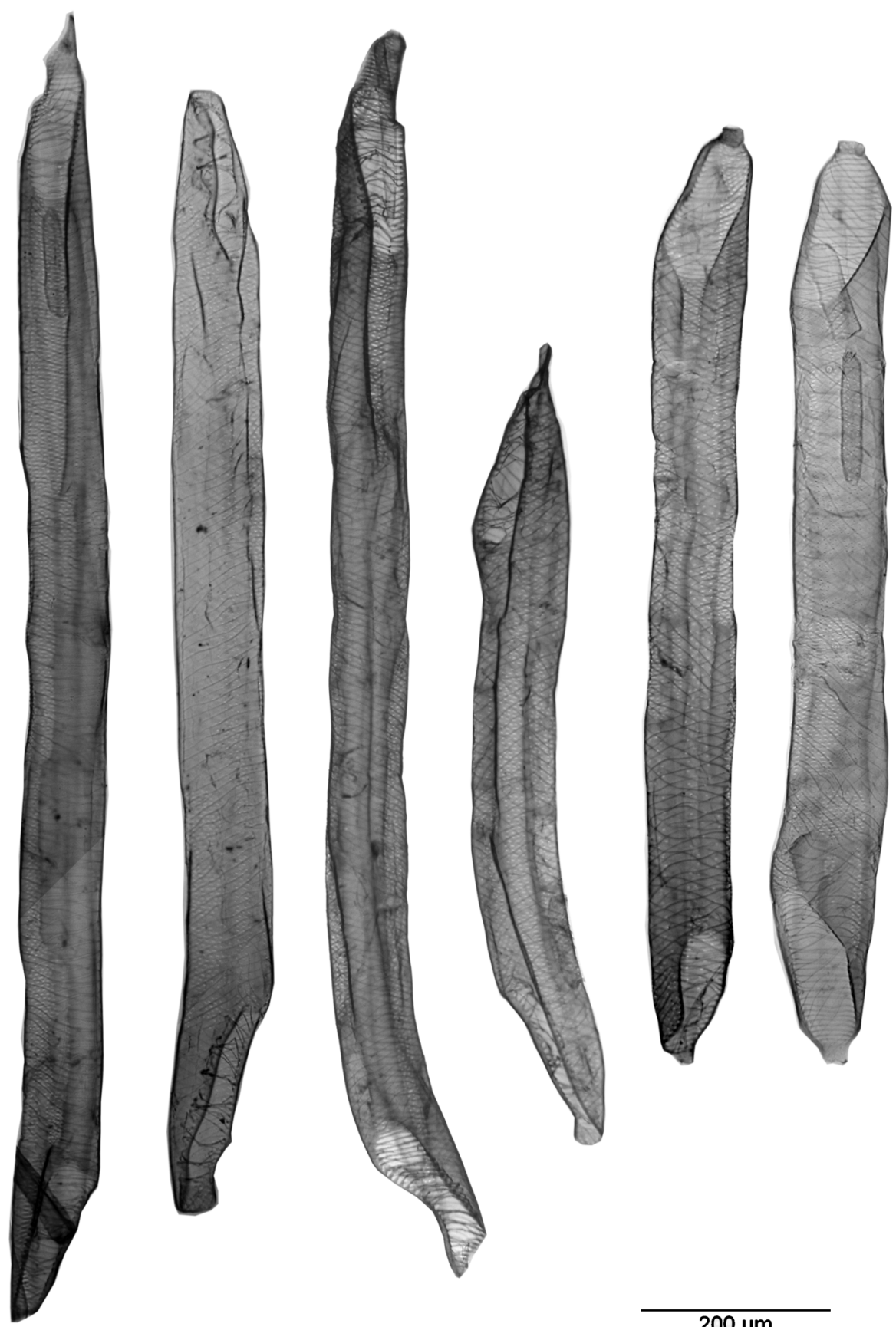

$200 \mu \mathrm{m}$

Ilex triflora var. kanehirai 


\section{Ilex triflora var. kanehirai (Yamamoto) S.Y. Hu (Aquifoliaceae)}

Trade names: san hua dong qing, yuan bian zhong (CN), kecemang (ID).

DIN EN 13556:2003 code: not listed.

CITES regulations: not protected.

Geographic distribution: China, Taiwan; The genus Ilex is almost cosmopolitan and occurs throughout tropical, subtropical and temperate regions of the world.

Vessel elements: quite long and slim (length about $1100 \mu \mathrm{m}$, width about $90 \mu \mathrm{m}$ ); tube-shaped.

Tails: long or short with gradual transition.

Perforation plates: scalariform (20-40 thin bars); extending over the entire lumen; inclined.

Intervessel pits: opposite; occasionally merging into a scalariform pattern; vertical diameter 2-4-5 um; oval to almost rectangular; sometimes covering a wide area of the vessel element wall.

Vessel-ray pits: APS; rarely present; arranged in blocks of several horizontally oriented, elongated pits (gash-like).

Pits to fibers: in single vertical rows.

Areas without any pits: regularly present; very large.

Tyloses: absent.

Helical thickenings: present in vessel elements, possibly also in fibers.

Notes on identification: In pulp and paper, the vessel elements of Ilex spp. are often accompanied by fibers with helical thickenings if they originate from subtropical or temperate regions. Most tropical species (like I. cymosa) do not have helical thickenings (Baas 1973).

\section{Quantitative data:}

Vessel elements (759-) 1098(-1430) $\mu \mathrm{m}$ long, and (52-) 89(-104) $\mu \mathrm{m}$ wide; $1 / \mathrm{w}$ ratio 12.4 .

Intervessel pit borders (2.4-) 3.5(-5.2) $\mu \mathrm{m}$ in vertical diameter; pit apertures (0.6-) $1.1(-1.9) \mu \mathrm{m}$.

Fibers $1290 \mu \mathrm{m}$ long, $34.4 \mu \mathrm{m}$ wide. Fiber wall thickness $4.1 \mu \mathrm{m}$ (weighted averages). 


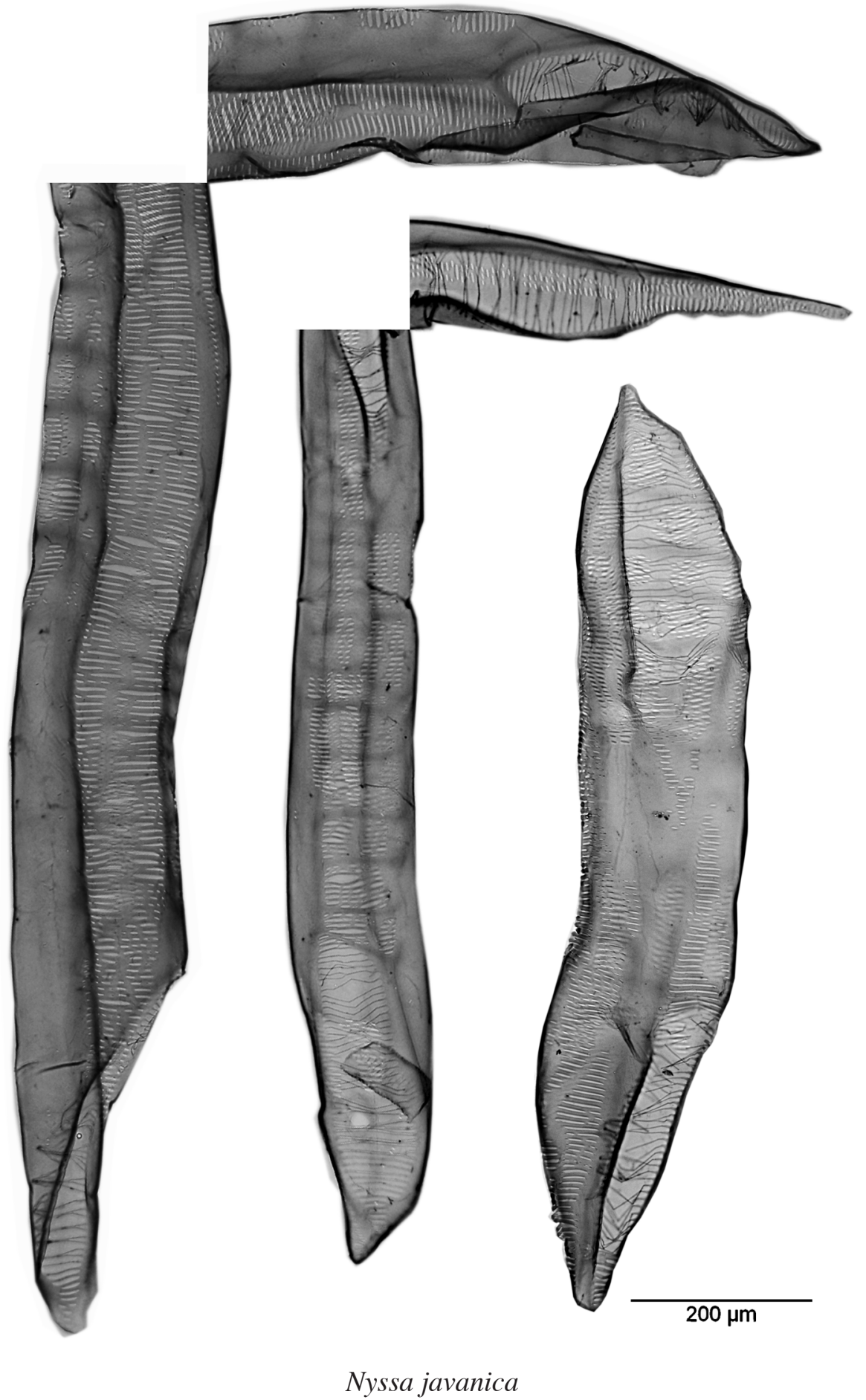




\section{Nyssa javanica (Blume) Wangerin (Nyssaceae)}

Trade names: kalay, hirun, chilauni (IN); thang khok, khai pla, khueng khak, mueat khon khao (TH); kirung, hirung, wuru gading, kapi dengkung (ID); terang bulu (MY); theun (LA). Similar species occur in North America.

DIN EN 13556:2003 code: NYAQ (Nyssa aquatica).

CITES regulations: not protected.

Geographic distribution: India, S-China, Malaysia, Indonesia, Indochina.

Vessel elements: very long and slim (length about $1500 \mu \mathrm{m}$, width about $180 \mu \mathrm{m}$ ); tube-shaped.

Tails: long with gradual transition.

Perforation plates: scalariform (20-30(-50) thin bars); bars sometimes branched; extending over the entire lumen; inclined.

Intervessel pits: opposite and scalariform; vertical diameter 3-5-9 $\mu \mathrm{m}$; more or less rectangular or elongated horizontally.

Vessel-ray pits: VAS; oval or elongated horizontally.

Pits to fibers: circular to oval in single vertical rows.

Areas without any pits: regularly present; large to very large.

Tyloses and helical thickenings: absent.

Notes on identification: Vessel elements of Nyssa spp. are similar to those of Liriodendron spp. and Alniphyllum spp. The pits to ray parenchyma cells differ (Nyssa spp. and Liriodendron spp. = VAS type, Alniphyllum spp. = APS type).

Nyssa spp. and Liriodendron spp. possess more numerous thin bars and opposite intervessel pits that distinguish them from Liquidambar spp. and Schima spp.

\section{Quantitative data:}

Vessel elements (736-) 1502(-2006) $\mu \mathrm{m}$ long, and (137-) 176(-200) $\mu \mathrm{m}$ wide; 1/w ratio 8.7 .

Intervessel pit borders (3.1-)5.4(-8.9) $\mu \mathrm{m}$ in vertical diameter; pit apertures (0.9-) $2.1(-3.9) \mu \mathrm{m}$.

Fibers $1350 \mu \mathrm{m}$ long, $27.0 \mu \mathrm{m}$ wide. Fiber wall thickness $3.0 \mu \mathrm{m}$ (weighted averages). 

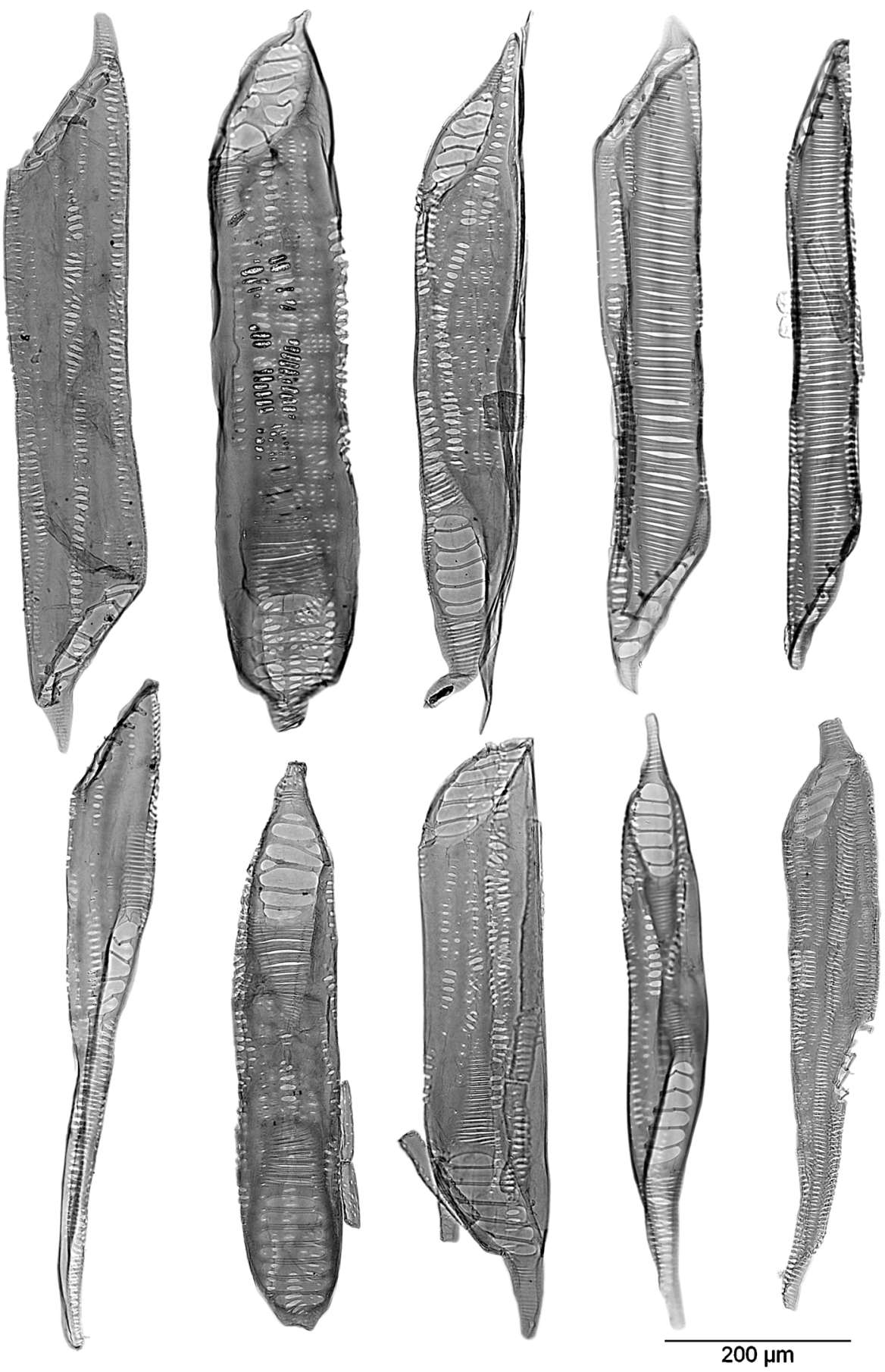

Rhizophora sp. 


\section{Rhizophora sp. (Rhizophoraceae)}

Trade name: red mangrove.

DIN EN 13556:2003 code: not listed.

CITES regulations: not protected.

Geographic distribution: Rhizophora is a pantropical mangrove genus, also widely distributed in the Asia-Pacific region.

Vessel elements: quite long and slim (length about $540 \mu \mathrm{m}$, width about $100 \mu \mathrm{m}$ ); tube-shaped.

Tails: long or short with gradual transition, covered with pits.

Perforation plates: scalariform (3-10 thin bars); bars can be branched; extending over the entire lumen; inclined (parallelogram or trapezium).

Intervessel pits: scalariform; vertical diameter 2-6-11 $\mu \mathrm{m}$.

Vessel-ray pits: VAS; oval to rectangular, sometimes opposite.

Pits to axial parenchyma cells: oval to gash-like; in vertical bands.

Areas without any pits: regularly present; large.

Tyloses: present.

Helical thickenings: absent.

Quantitative data:

Vessel elements (317-)543(-824) $\mu \mathrm{m}$ long, and (59-) 104(-145) $\mu \mathrm{m}$ wide; $1 / \mathrm{w}$ ratio 5.3.

Intervessel pit borders (2.4-) 5.6(-10.8) $\mu \mathrm{m}$ in vertical diameter; pit apertures (0.7-) $2.5(-7.1) \mu \mathrm{m}$.

Fibers $1065 \mu \mathrm{m}$ long, $26.4 \mu \mathrm{m}$ wide. Fiber wall thickness $5.9 \mu \mathrm{m}$ (weighted averages). 


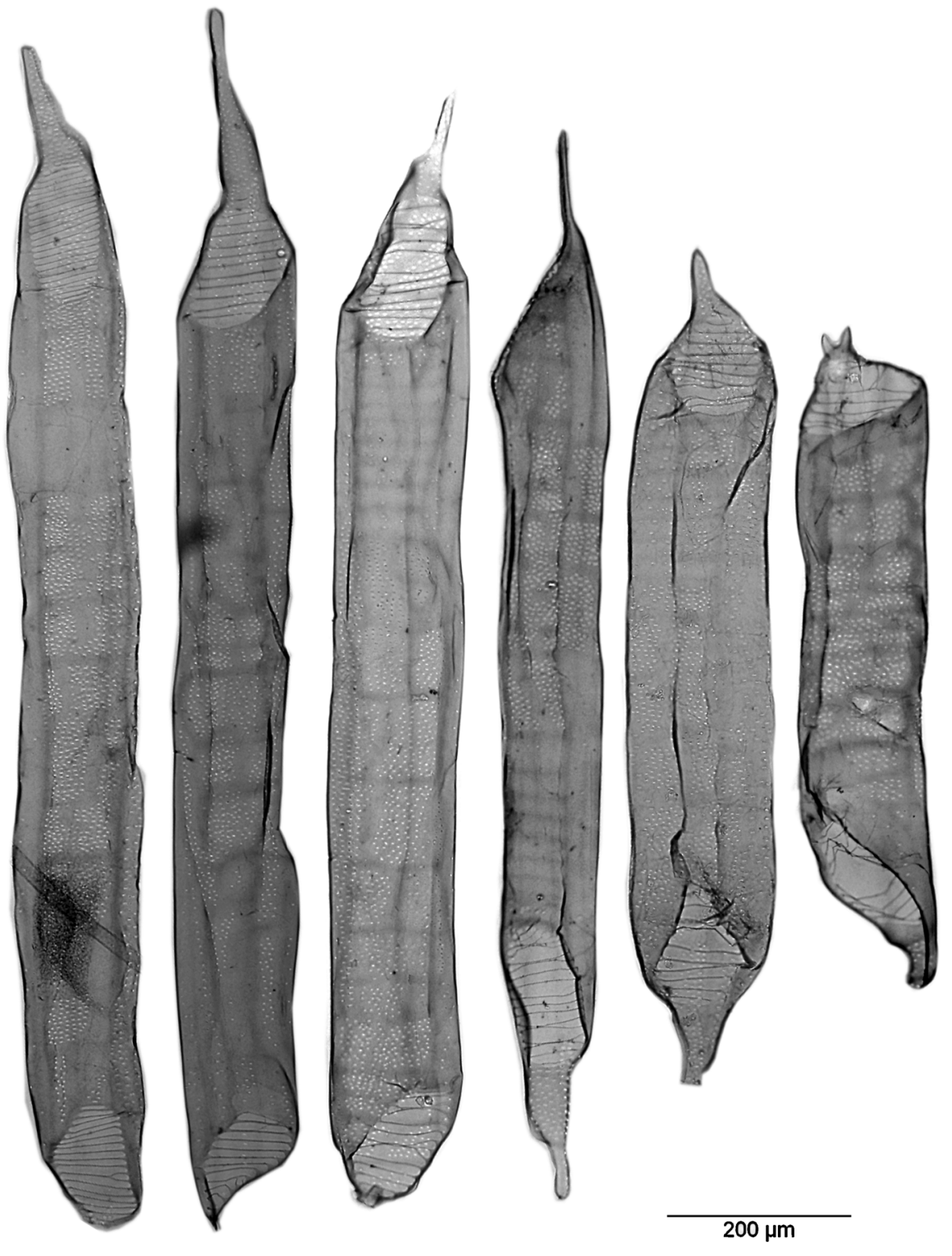

Alniphyllum pterospermum 


\section{Alniphyllum pterospermum Matsum. (Styracaceae)}

Trade names: chi-yang-ye (CN); mee dong (LA).

DIN EN 13556:2003 code: not listed.

CITES regulations: not protected.

Geographic distribution: China, Taiwan, Laos, Vietnam.

Vessel elements: rather long and slim (length about $1080 \mu \mathrm{m}$, width about $140 \mu \mathrm{m}$ ); tube-shaped.

Tails: mostly long with gradual transition, or short.

Perforation plates: scalariform (8-15 bars); bars can be branched; extending over the entire lumen; inclined.

Intervessel pits: alternate or opposite; vertical diameter 3-5-7 $\mu \mathrm{m}$.

Vessel-ray pits: APS; similar to intervessel pits; forming well-defined blocks of a shape corresponding to the respective ray cells.

Pits to fibers: present in single vertical rows.

Areas without any pits: regularly present; large.

Tyloses and helical thickenings: absent.

Notes on identification: Vessel elements of Alniphyllum spp. are similar to those of Nyssa spp. (see Nyssa javanica, p. 342).

\section{Quantitative data:}

Vessel elements (828-) 1081(-1433) $\mu \mathrm{m}$ long, and (103-) $137(-170) \mu \mathrm{m}$ wide; 1/w ratio 8.1.

Intervessel pit borders (3.3-) 4.6(-6.6) $\mu \mathrm{m}$ in vertical diameter; pit apertures $(0.8-)$ $1.3(-2.1) \mu \mathrm{m}$.

Fibers $1440 \mu \mathrm{m}$ long, $35.7 \mu \mathrm{m}$ wide. Fiber wall thickness $3.7 \mu \mathrm{m}$ (weighted averages). 

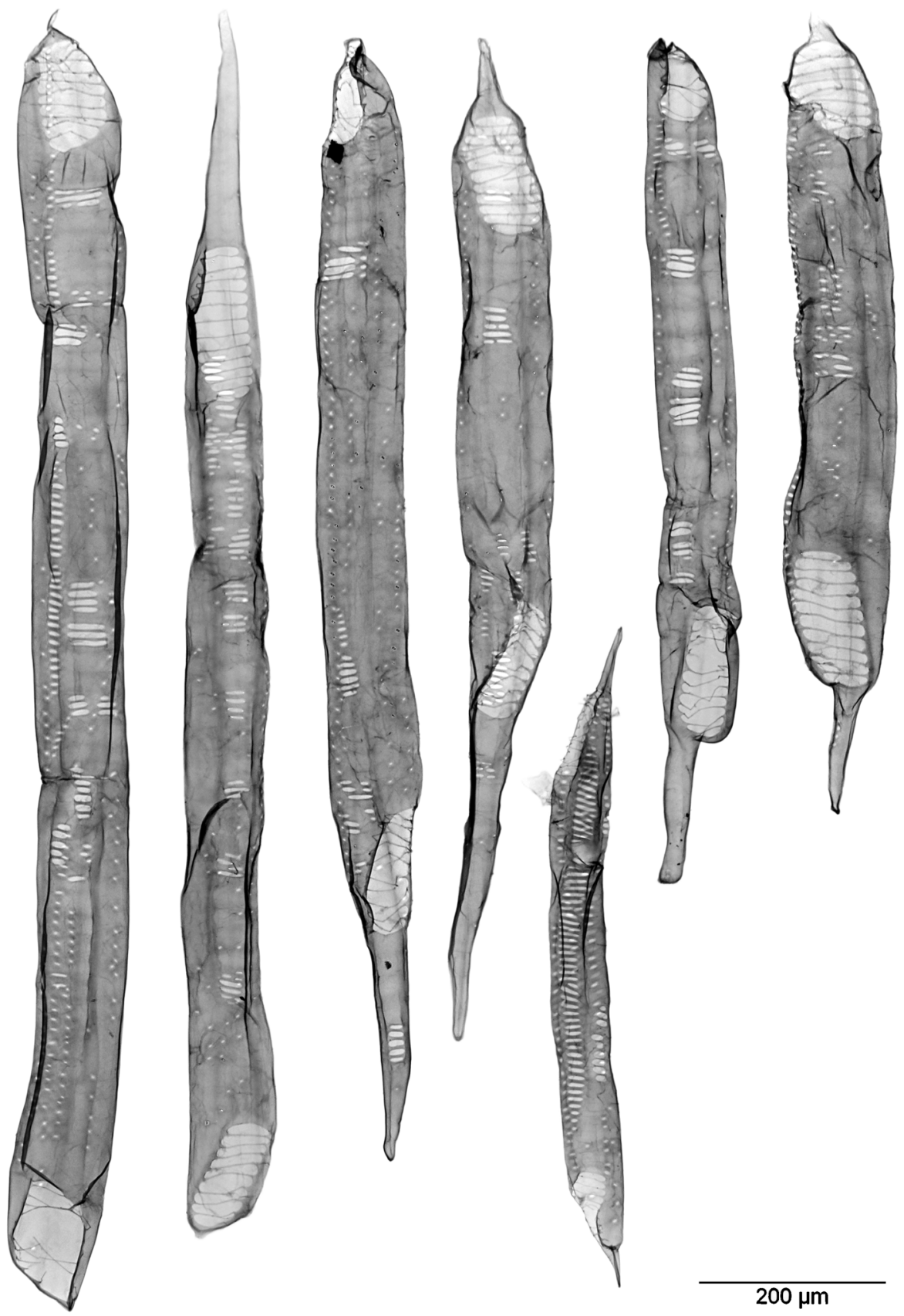

Schima superba 


\section{Schima superba Gardn. \& Champ. (Theaceae)}

Trade names: puspa, seru (ID); medang gatal, samak (MY); Chinese guger tree (TW, US); laukya (MM); gaobei, huazi (CN); needlewood (GB); chilauni (IN); thalo, champa dong $(\mathrm{TH})$.

DIN EN 13556: 2003 code: not listed.

CITES regulations: not protected.

Geographic distribution: China, Taiwan, Ryukyu Islands. The genus Schima also occurs in tropical Malaysia and Indonesia.

Vessel elements: long and slim (length about $1210 \mu \mathrm{m}$, width about $90 \mu \mathrm{m}$ ); tubeshaped.

Tails: long with gradual transition.

Perforation plates: scalariform (5-15 bars); bars can be branched; extending over the entire lumen; inclined.

Intervessel pits: rarely present; vertical diameter 4-7-9 $\mu \mathrm{m}$; scalariform; forming vertical series of horizontally elongated pits.

Vessel-ray pits: VAS; two size classes; oval or elongated horizontally (gash-like) arranged in short to long horizontal rows (opposite) or in a ladder-like series (scalariform).

Pits to fibers: circular, often present in single vertical rows.

Areas without any pits: regularly present; large.

Tyloses: present.

Helical thickenings: may be present at the end of the tails.

Notes on identification: Vessel elements of Schima spp. are similar to those of Liquidambar spp. (see Liquidambar formosana, p. 338).

\section{Quantitative data:}

Vessel elements (836-) 1208 (-1414) $\mu \mathrm{m}$ long, and (80-) 89(-103) $\mu \mathrm{m}$ wide; $1 / \mathrm{w}$ ratio 13.6 .

Intervessel pit borders (4.0-)6.5(-9.1) $\mu \mathrm{m}$ in vertical diameter; pit apertures $(0.5-)$ $1.4(-3.8) \mu \mathrm{m}$.

Fibers $1350 \mu \mathrm{m}$ long, $30.5 \mu \mathrm{m}$ wide. Fiber wall thickness $3.3 \mu \mathrm{m}$ (weighted averages). 


\section{CONCLUSION}

The identification of internationally traded wood and wood products is of prime importance in enforcing the legal utilization of wood, especially in pulp and paper which is traded on the largest scale. The identification of individual cell elements (vessels) requires a standardized morphological description with high quality images which is now available for the most important tropical timber species from Asia. Since the fiber components of pulp and paper are subjected to the strict control of the European Timber Regulation (EUTR) from March 2013 onwards, we daily receive samples for checking the declarations from trading companies and competent authorities. In this context, we successfully tested earlier versions of this vessel atlas as an integrated part of our identifications. However, it is obvious that the present Atlas still has weaknesses such as: 1) limited number of taxa included; 2) insufficient sampling to evaluate the full range of variation in vessel element morphology, especially for quantitative parameters at both the species, subgenus and genus level. Future work is necessary to continuously extend the database by describing further unknown or lesser known species.

\section{ACKNOWLEDGEMENTS}

This work was funded by the German Environmental Foundation (Deutsche Bundesstiftung Umwelt, DBU) in the framework of two consecutive projects, "Identification of Mixed Tropical Hardwood (MTH) in paper - a contribution to species protection" (Grant/Award Number: AZ 29436) and "Identification of Mixed Tropical Hardwood (MTH) in paper by chemotaxonomic and morphologic characteristics" (Grant/Award Number: AZ 31759-31).

Research work was supported by the theses of Arne Kuck, Saskia Poth and Lena Tepe (M.Sc. of Wood Science, Zentrum Holzwirtschaft, University of Hamburg, Germany).

We want to express our sincere thanks to Dr. Hans-Georg Richter for his valuable suggestions and critical reviewing of the atlas.

\section{ABBREVIATIONS}

APS - all pits similar in size and shape EUTR - European Timber Regulation IVP - intervessel pit MTH - Mixed Tropical Hardwood PAP - pit to axial parenchyma cell

\author{
PF - pit to fiber \\ PT - pit to tracheid \\ VAS - vessel-ray pit apparently simple \\ VRP - vessel-ray pit
}

Codes of two capital letters are according to ISO 3166 (except BN)

$\begin{array}{lll}\text { AU = Australia } & \text { JP = Japan } & \text { NP = Nepal } \\ \mathrm{BN}=\text { Borneo } & \mathrm{KH}=\text { Cambodia } & \mathrm{PA}=\text { Panama } \\ \mathrm{BR}=\text { Brazil } & \mathrm{LA}=\text { Laos } & \mathrm{PG}=\text { Papua New Guinea } \\ \mathrm{CN}=\text { China } & \mathrm{LK}=\text { Sri Lanka } & \mathrm{PH}=\text { Philippines } \\ \mathrm{DE}=\text { Germany } & \mathrm{MG}=\text { Madagascar } & \mathrm{SAM}=\text { South Americas } \\ \mathrm{FR}=\text { France } & \mathrm{MM}=\text { Myanmar (Burma) } & \mathrm{TH}=\text { Thailand } \\ \mathrm{GB}=\text { Great Britain } & \mathrm{MY}=\text { Malaysia } & \mathrm{TW}=\text { Taiwan } \\ \text { ID = Indonesia } & \mathrm{MY} \text {-sab = Malaysia-Sabah } & \text { US = United States of America } \\ \text { ID-kal = Indonesia-Kalimantan } & \mathrm{MY} \text {-swk = Malaysia-Sarawak } & \mathrm{VN}=\text { Vietnam } \\ \text { IN = India } & \mathrm{NL}=\text { Netherlands } & \end{array}$




\section{REFERENCES}

Baas P. 1973. The wood anatomical range in Ilex (Aquifoliaceae) and its ecological and phylogenetic significance. Blumea 21: 193-258.

Brink M, Escobin RP (eds.). 2003. Plant Resources of South-East Asia No. 17. Fibre plants. Backhuys Publishers, Leiden. 456 pp.

Carlquist S. 2001. Comparative wood anatomy. Systematic, ecological, and evolutionary aspects of dicotyledon wood. Springer, Berlin, Heidelberg, New York.

Carpenter CH, Leney L. 1952. 382 photomicrographs of 91 papermaking fibers. State of University of New York, College of Forestry at Syracuse.

Catalogue of life. March 2017. http://www.catalogueoflife.org/col/search.

Core HA, Côté WA, Day AC. 1979. Wood structure and identification. Syracuse University Press, New York.

De Micco V, Balzano A, Wheeler EA, Baas P. 2016. Tyloses and gums: a review of structure, function and occurrence of vessel occlusions. IAWA J. 37: 186-205.

Dormontt EE, Boner M, Braun B, Breulmann G, Degen B, Espinoza E, Gardner S, Guillery P, Hermanson JC, Koch G, Lee SL, Kanashiro M, Rimbawanto A, Thomas D, Wiedenhoeft AC, Yin Y, Zahnen J. 2015. Forensic timber identification: it's time to integrate disciplines to combat illegal logging. Biol. Conserv. 191: 790-798.

Dujesiefken D, Liese W. 2008. Das CODIT-Prinzip. Haymarket Media, Braunschweig.

Ezpeleta LB, Simon JLS. 1970. Atlas de fibras para pasta de celulosa II parte. Vol. 1. Ministerio de Agricultura, Madrid. 107 pp.

Ezpeleta LB, Simon JLS. 1971. Atlas de fibras para pasta de celulosa II parte. Vol. 2. Ministerio de Agricultura, Madrid. 89 pp.

FAO. 03. 2015. http://faostat3.fao.org/browse/F/*/E.

Flora of China. 17 July 2017. www.efloras.org.

Franke W. 1993. Prüfung von Papier, Pappe, Zellstoff und Holzstoff: Bd. 2 Mikroskopische und photometrische Verfahren. Springer-Verlag, Berlin, Heidelberg.

Franklin GL. 1945. Preparation of thin sections of synthetic resins and wood-resin composites, and a new maceration method for wood. Nature 155: 51.

Greenpeace. 2012. The Ramin Paper Trail. Asia pulp \& paper under investigation. Part 2. http://www.greenpeace.org/international/en/publications/Campaign-reports/Forests-Reports/ The-Ramin-Paper-Trail/, Publication, 1 March, 2012.

Grin. March 2017. URL: https://npgsweb.ars-grin.gov.

Harders-Steinhäuser M. 1974. Faseratlas zur mikroskopischen Untersuchung von Zellstoffen und Papieren. Güntter-Staib-Verlag, Biberach/Riß.

Hayashi S, Kishima T, Lau LC, Wong TM, Menon PKB. 1973. Micrographic atlas of Southeast Asian timber. Nakanishi Printing Co., Ltd., Kyoto, Japan.

Helmling S, Olbrich A, Tepe L, Koch G. 2016. Qualitative and quantitative characteristics of macerated vessels of 23 mixed tropical hardwood (MTH) species: a data collection for the identification of wood species in pulp and paper. Holzforschung 70: 839-844.

IAWA Committee. 1964. Multilingual glossary of terms used in wood anatomy. Konkordia, Winterthur.

IAWA Committee. 1989. IAWA list of microscopic features for hardwood identification. IAWA Bull. n.s. 10: 221-332.

Ilvessalo-Pfäffli M-S. 1995. Fiber atlas - Identification of papermaking fibers. Springer Series in Wood Science, Springer-Verlag, Berlin, Heidelberg. 
InsideWood. 2004-onwards. Published on the Internet. http://insidewood.lib.ncsu.edu/search. Jiang Z. 2013. Wood properties of the global important tree species. Science Press, Beijing.

Koch G, Haag V, Heinz I, Richter H-G, Schmitt U. 2015. Control of internationally traded timber - the role of macroscopic and microscopic wood identification against illegal logging. J. Forensic Res. 6 (6): 1000317.

Koch G, Schmitt U. 2015. Control and requirements for internationally traded wood and wood products - EU Timber Regulation: wood identification. In: Vietnam Forestry University (ed.), Proceedings International Workshop on Wood Science at Vietnam Forestry University (VFU), Hanoi, pp. 7-12.

Lemmens RHMJ, Soerianegara I, Wong WC (eds.). 1995. Plant Resources of South-East Asia No 5 (2). Timber trees: Minor commercial timbers. Backhuys Publishers, Leiden. 655 pp.

Liese W. 1997. Structural research issues on bamboo. INBAR Newsletter 5 (1 \& 2): 27-29.

Liese W. 1998. The anatomy of bamboo culms. Technical report, Beijing.

Mabberley DJ. 2008. Mabberley's Plant-book. University of Washington Botanic Gardens, Seattle, Cambridge University Press.

Nygård M. 2006. kajaaniFiberLab ${ }^{\text {TM }}$ - operating manual K02642 V1.0 DE. Translation: Gehl U, Metso Automation Inc., Field Systems Division.

Parham RA, Gray RL. 1982. The practical identification of wood pulp fibers. Tappi Press, Atlanta.

Richter HG, Dallwitz MJ. 2000-onwards. Commercial timbers: descriptions, illustrations, identification and information retrieval. In English, French, German, and Spanish; deltaintkey.com.

Schmitt U, Liese W. 1994. Wound tyloses in Robinia pseudoacacia L. IAWA J. 15: 157-160.

Soerianegara I, Lemmens RHMJ (eds.). 1993. Plant Resources of South-East Asia No 5 (1). Timber trees: Major commercial timbers. Pudoc Scientific Publishers, Wageningen. 610 pp. Sosef MSM, Hong LT, Prawirohatmodjo S (eds.). 1998. Plant Resources of South-East Asia No 5 (3). Timber trees: Lesser-known timbers. Backhuys Publishers, Leiden. 859 pp.

Weiner G, Liese W. 1995. Wound response in the stem of the royal palm. IAWA J. 16: 433442.

Wheeler EA. 2011. InsideWood - a web resource for hardwood anatomy. IAWA J. 32: 199_ 211.

Williams J. 2014. Environmental aspects of China's papermaking fiber supply - Update. Forest Trends Report Series, Forest Trade and Finance.

Wong TM. 2002. A dictionary of Malaysian timbers. Malayan Forest Records No. 30. The Forest Research Institute Malaysia, Percetakan Haji Jantan, Kuala Lumpur, Malaysia. WWF Deutschland. 2009. Tropenwaldzerstörung für Kinderbücher, Frankfurt a.M. 